\title{
Germany: 2008 Article IV Consultation-Staff Report; Staff Supplement; Public Information Notice on the Executive Board Discussion; and Statement by the Executive Director for Germany
}

Under Article IV of the IMF's Articles of Agreement, the IMF holds bilateral discussions with members, usually every year. In the context of the 2008 Article IV consultation with Germany, the following documents have been released and are included in this package:

- $\quad$ The staff report for the 2008 Article IV consultation, prepared by a staff team of the IMF, following discussions that ended on November 24, 2008, with the officials of Germany on economic developments and policies. Based on information available at the time of these discussions, the staff report was completed on December 9, 2008. The views expressed in the staff report are those of the staff team and do not necessarily reflect the views of the Executive Board of the IMF.

- $\quad$ A staff supplement of January 13, 2009, updating information on recent developments

- $\quad$ A Public Information Notice (PIN) summarizing the views of the Executive Board as expressed during its January 14, 2009 discussion of the staff report that concluded the Article IV consultation.

- A statement by the Executive Director for Germany.

The policy of publication of staff reports and other documents allows for the deletion of market-sensitive information.

Copies of this report are available to the public from

International Monetary Fund $\bullet$ Publication Services

$70019^{\text {th }}$ Street, N.W. $\bullet$ Washington, D.C. 20431

Telephone: (202) 623-7430 • Telefax: (202) 623-7201

E-mail: publications@imf.org •Internet: http://www.imf.org

Price: $\$ 18.00$ a copy

\section{International Monetary Fund Washington, D.C.}





\title{
INTERNATIONAL MONETARY FUND
}

\author{
GERMANY
}

\section{Staff Report for the 2008 Article IV Consultation}

\author{
Prepared by the Staff Representatives for the 2008 Consultation with Germany
}

Approved by Marek Belka and Tamim Bayoumi

December 9, 2008

\section{Executive Summary}

Germany faces the prospect of a sizeable, and possibly extended, economic downturn. Following contraction in the second and third quarters of 2008, a further four quarters of negative GDP growth appear likely. In 2009 , GDP is projected to fall by 0.8 percent and a sluggish 0.5 percent growth in 2010 would be well below the potential of about $1 \frac{1}{2}$ percent. The risk is that corporate and financial sector stresses, thus far dissociated from each other in Germany, may become more intertwined. The longer the global shocks persist, the more severe and prolonged would the weakness be.

The authorities have stepped in to protect financial stability. Following the public commitment to fully protect household deposits, the newly-constituted Financial Market Stabilization Fund (FMSF) is to address urgent vulnerabilities - banks' liquidity, short-term funding, and capitalization. A few transactions have been completed. However, banks face new risks through weakening corporate credit and exposures to emerging markets. It remains important that the Landesbanken be downsized and merged to form viable financial entities for private ownership and operation. The authorities acknowledge the challenge and are examining various options.

This crisis has highlighted the need-and created an opportunity-for overhauling the framework for financial stability and prudential regulation. Though faced by legal and political constraints, the authorities are exploring instituting a bank resolution mechanism that can respond in a more timely manner, while also rationalizing the patchwork of deposit insurance schemes within Germany. The global lessons from the crisis will require regulatory and supervisory enhancements. And, as the authorities also recognize, the process of further clarification of authority and accountability within the German system of prudential regulation and supervision must continue.

The generally sound fiscal position leaves room for a sizable but targeted stimulus to counter the adverse developments. The authorities regard the measures taken so far as sufficient, but to be complemented, if necessary, with additional stimulus. Staff argued for a more ambitious stimulus now. Targeted payments to economically-weak households could initially raise confidence and spending. Bringing forward the planned reductions in social security contributions and accelerated infrastructure spending could have a stimulus effect with longer-term benefits. However, commitment to long-term fiscal sustainability through the proposed fiscal rule is necessary, as the authorities recognize. Cost efficiencies in healthcare and reform of fiscal federalism remain medium-term challenges despite recent commendable gains in the state of public finances. 


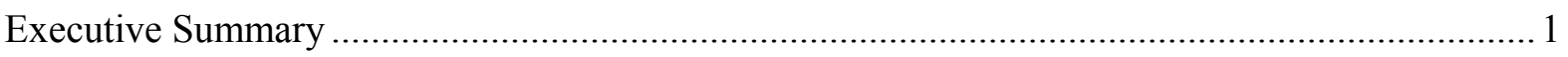

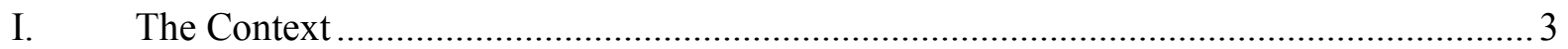

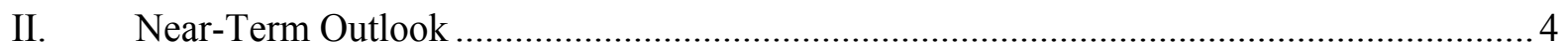

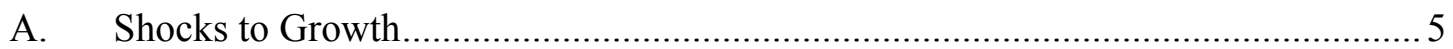

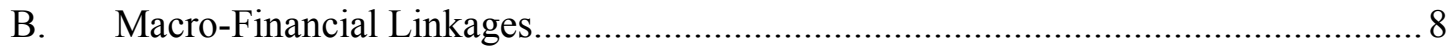

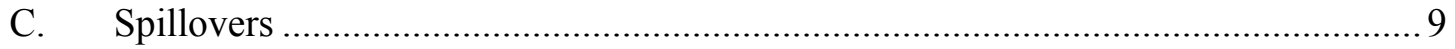

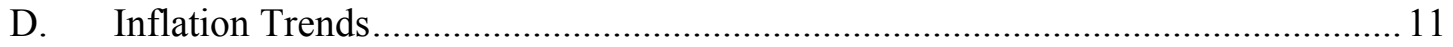

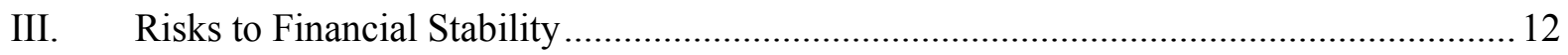

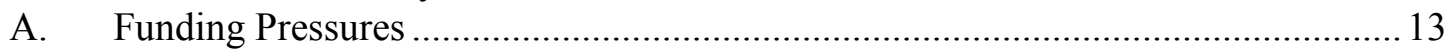

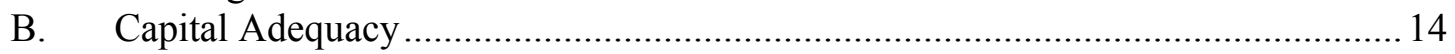

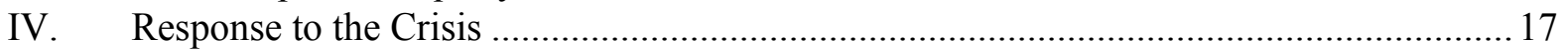

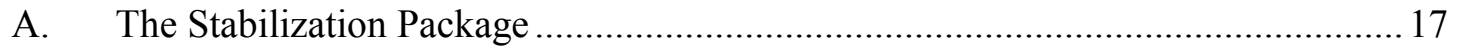

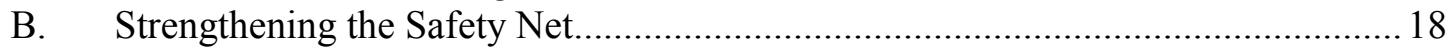

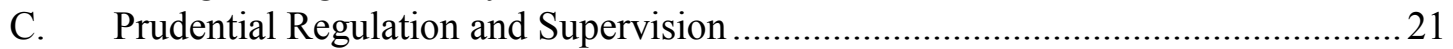

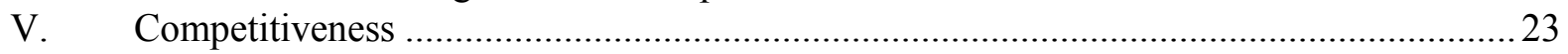

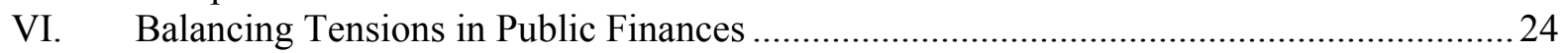

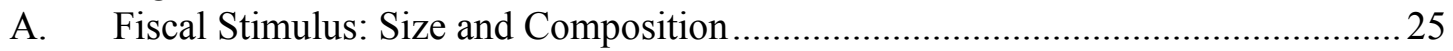

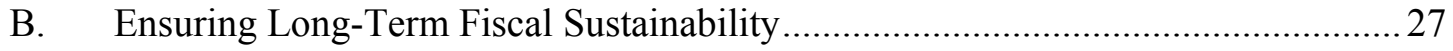

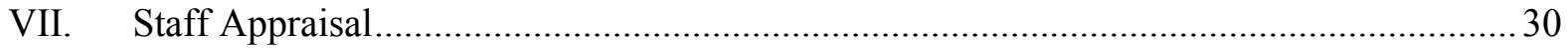

Boxes

1. Volatility from Global Spillovers Add to German Angst ................................................ 7

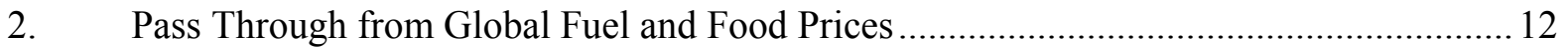

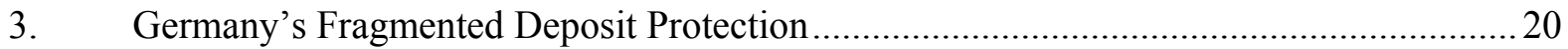

4. Fiscal Discipline in Germany: A Federal Matter? ........................................................... 29

Figures

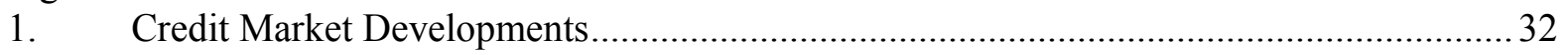

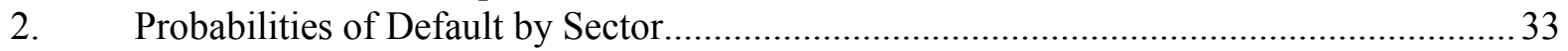

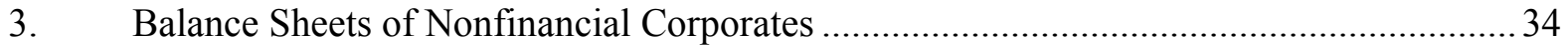

4. Central and Eastern Europe: Spillovers from Germany............................................... 35

Tables

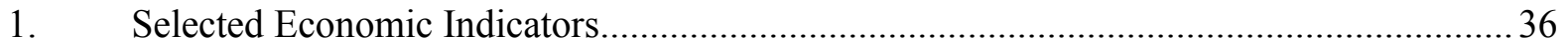

2. Foreign Claims of Banks on Individual Countries, November 2008............................. 38

3. Core Set of Financial Indicators for Banks, 1999-2007 ............................................... 39

4. Encouraged and Other Financial Soundness Indicators, 1999-2007 .............................. 40

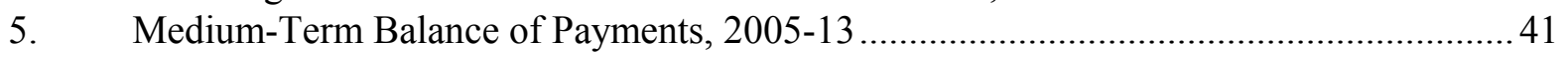

6. General Government: Government Operations ...................................................... 42

7. Expenditures Under the Authorities' Stimulus Packages, October and November, 2008.44

Annexes

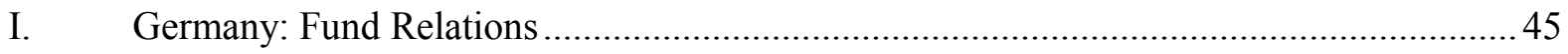

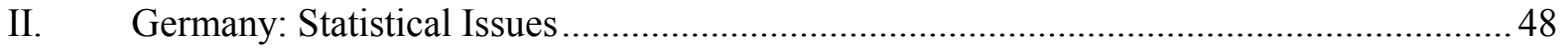




\section{The CONTEXT ${ }^{1}$}

1. The authorities have stepped in to protect financial stability. Germany felt the force of the first shocks from the subprime mortgage markets in July 2007. Two banks-IKB and Sachsen LB - had to be rescued at significant cost to the German taxpayer. While the traditional strengths of the German financial system - its retail deposit base and low indebtedness of households and businesses - apparently put a cap on the exposure of the system, systemic concerns have remained live. Following the failure of Lehman Brothers, the liquidity rollover requirements at Hypo Real Estate in early October 2008 were another threat to financial stability. The public commitment to protect household deposits provided initial reassurance. This was followed by a comprehensive package in mid-October to support market liquidity and bank capitalization.

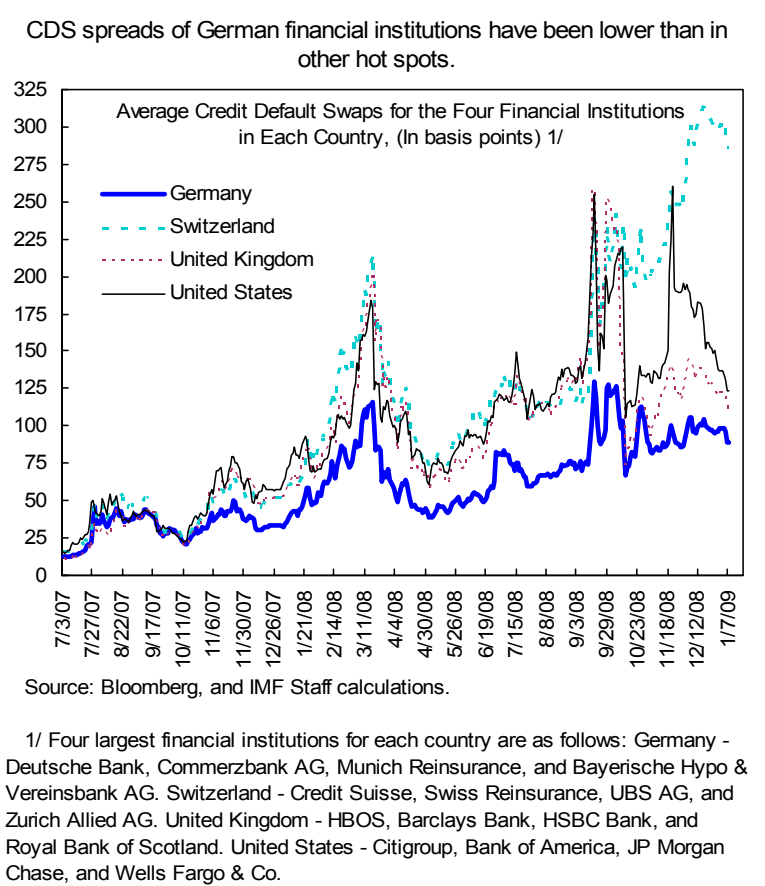

2. Given strong spillovers, policy measures to contain the risk of a self-reinforcing and costly slump will achieve more if coordinated internationally. Global impulses, felt forcefully in Germany, are rapidly transmitted to other economies. A German economic slowdown lowers growth in the rest of Europe, which feeds back to Germany. Moreover, a likely reduction of German banks' exposure to emerging markets would generate cascading spillovers. Thus, giving due consideration to its domestic objectives, Germany stands to benefit from an internationally coordinated approach to managing global risks.

- In this regard, actions to strengthen the financial safety net will buttress the recent initiatives. Germany's request for an FSAP update is timely.

- A similar risk management philosophy should apply to economic, especially fiscal, policy

\footnotetext{
${ }^{1}$ The staff team comprised Mr. Ashoka Mody (head), Mmes. Alina Carare, Franziska Ohnsorge (EUR); Messrs. Andreas Jobst, Steven Seelig (MCM), Sven Jari Stehn (FAD) and Ms. Maike Luedersen (LEG). The mission took place during November 12-24, 2008.
} 


\section{NEAR-TERM OUTLOOK}

3. The German economy is experiencing a sharp turnaround. The ongoing fall in confidence-especially in business

confidence, reflecting the sharp drop in foreign orders - accelerated with the elevated financial stress since September 2008.

Following robust GDP growth at an annualized rate of about $3 \frac{1}{2}$ percent just before the crisis hit in mid-2007, the economy contracted in the second and third quarters of 2008, and a further four quarters of negative GDP growth now appear likely. The expected turnaround reflects German volatility to external impulses (as discussed below), and is larger than in all other G-7 countries except the United Kingdom.

\section{Staff's and authorities' growth} projections have largely converged, and the risks are viewed as tilted principally to the downside. Broadly in line with the authorities' projections, staff expects GDP to grow at 1.7 percent in 2008 , followed by a
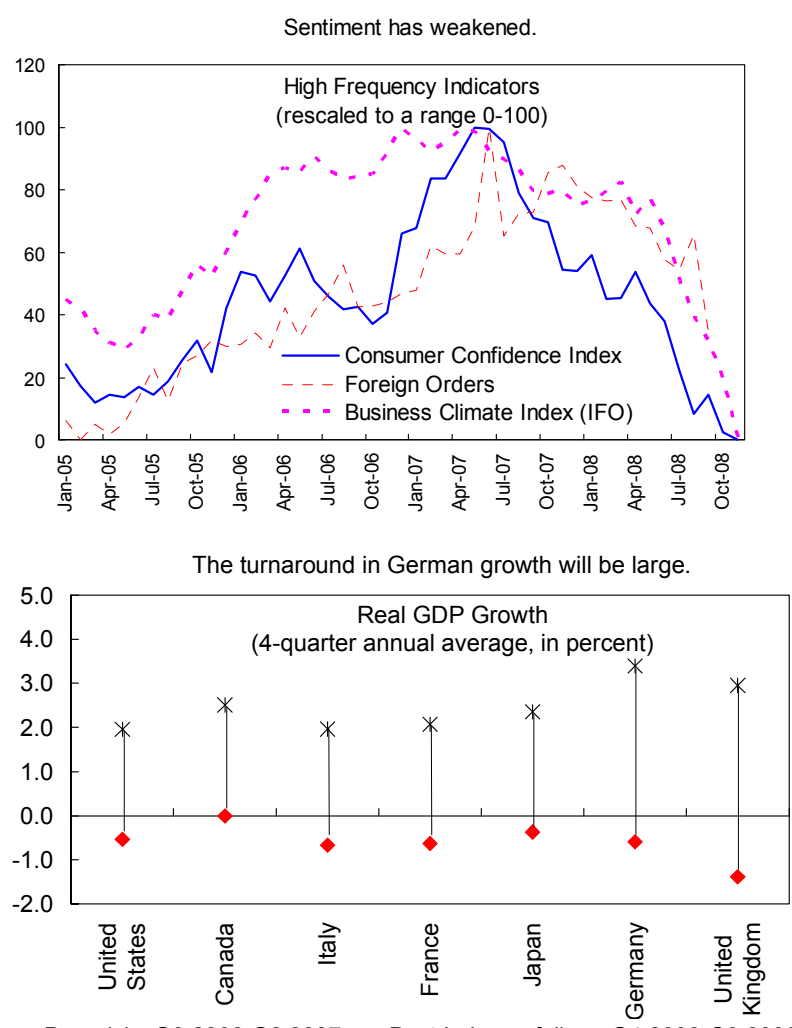

* Pre-crisis, Q3 2006-Q2 2007 Post-Lehman failure, Q4 2008-Q3 2009 1/ Based on November World Economic Outlook Quarterly Forecast Update.

contraction of 0.8 percent in 2009 (Table 1). The projection of a tentative recovery in 2010 reflects the assessment that the recent upswing was not associated with sustained productivity gains, and financial restructuring will also dampen growth. Corporate and financial sector stresses, thus far dissociated from each other in Germany, may become more intertwined. Moreover, the longer the global shocks persist, the more severe and prolonged would the weakness be.
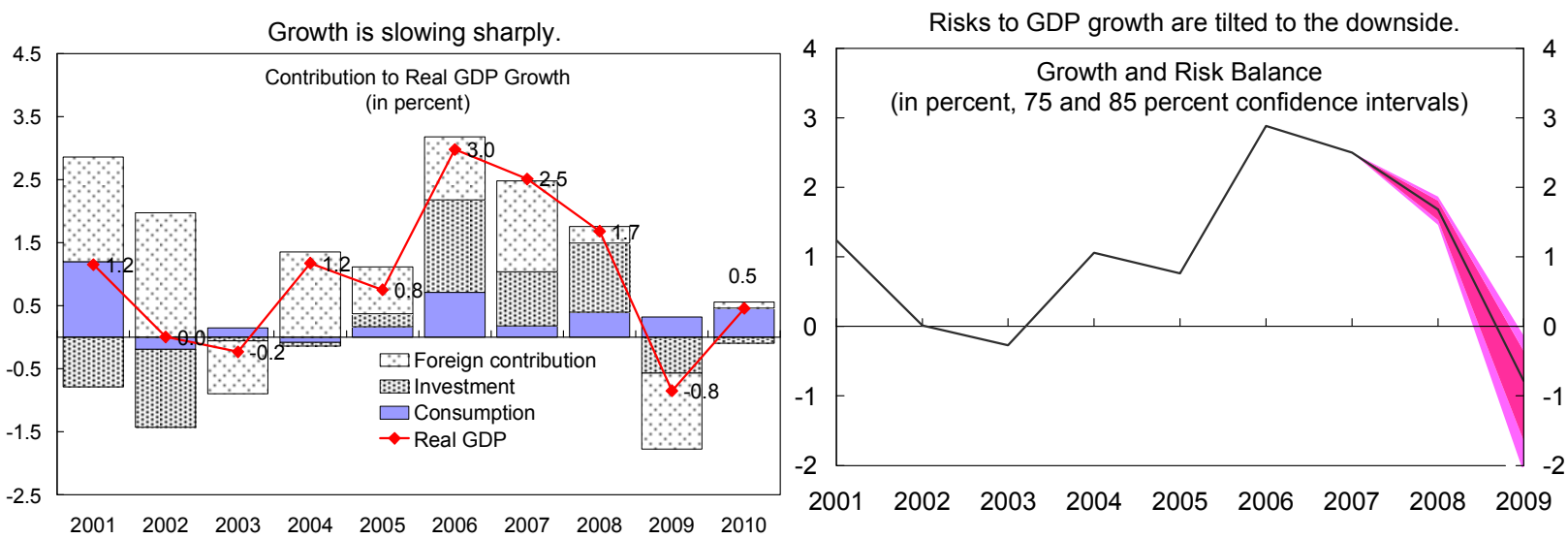
5. Whether — and the degree to which-downside risks materialize will depend on the evolution of expectations. The economy is being driven, in part, by current conditions but, increasingly, by expectations with regard to the next 6 to 12 months. The forward-looking sentiment is at historic lows.

Moreover, the gap between the perception of the present and the future has grown sharply, to an unprecedented size. Pessimistic expectations may further worsen operating conditions and hence become self-fulfilling. As such, to the extent that the forward-looking

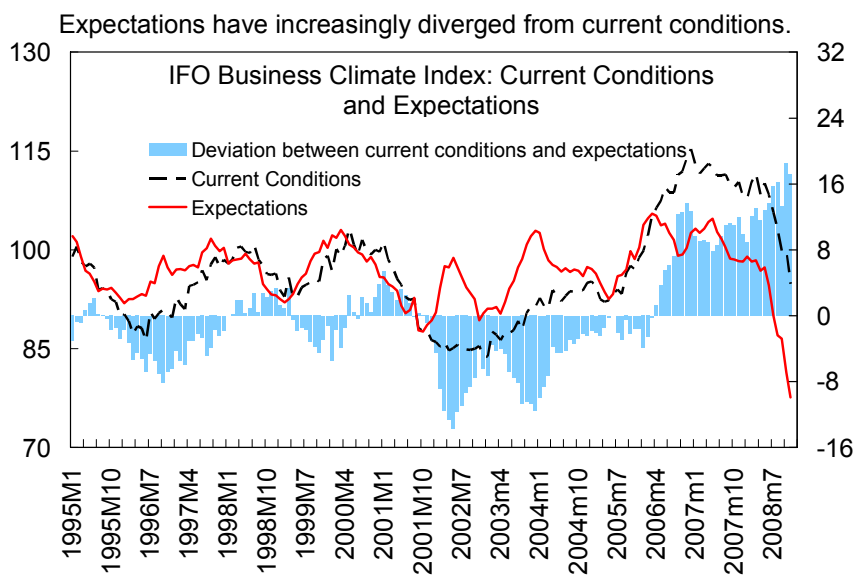
indicators remain at low levels, they may create a further drag on the economy, and pull the economy into scenarios below the baseline projection.

\section{A. Shocks to Growth}

6. The primary shock has been slowing world demand. Since the mid-1990s, German growth has been powered by exports. Not surprisingly, the principal source of the current slowdown has been the curtailment of foreign orders. The projected weakness of the world economy (and especially the U.S. economy) implies that this source of growth will remain heavily restricted. Movements in the euro exchange rate have some bearing on German exports, but staff analysis suggests that they mainly cause a shift in composition rather than a significant overall change.
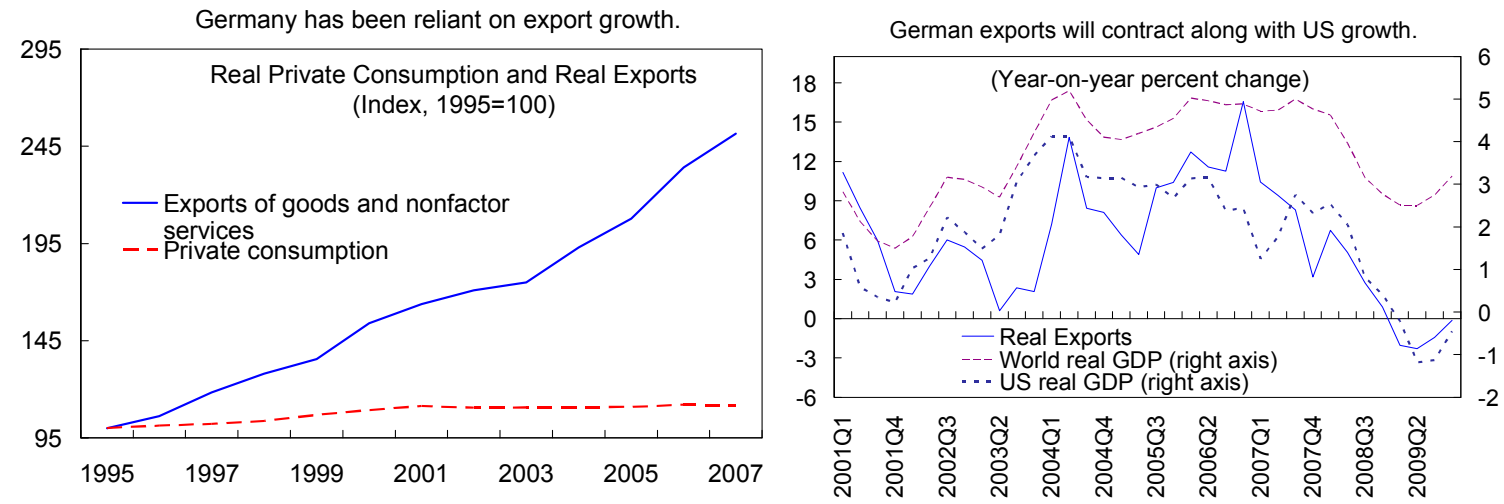

7. The German consumer's conservatism will continue to amplify the deceleration. The German consumer remained on the sidelines during the recent upswing. Even when employment and earnings began to finally increase towards the peak of the cycle, the threat of inflation apparently held consumption back. The authorities emphasize some temporary 
improvement in consumption from lower oil prices and the current labor market conditions. However, staff views low consumption growth to reflect a strong preference for precautionary savings in Germany. Increased exposure to volatility from global spillovers has recently held consumption back (Box 1 below).

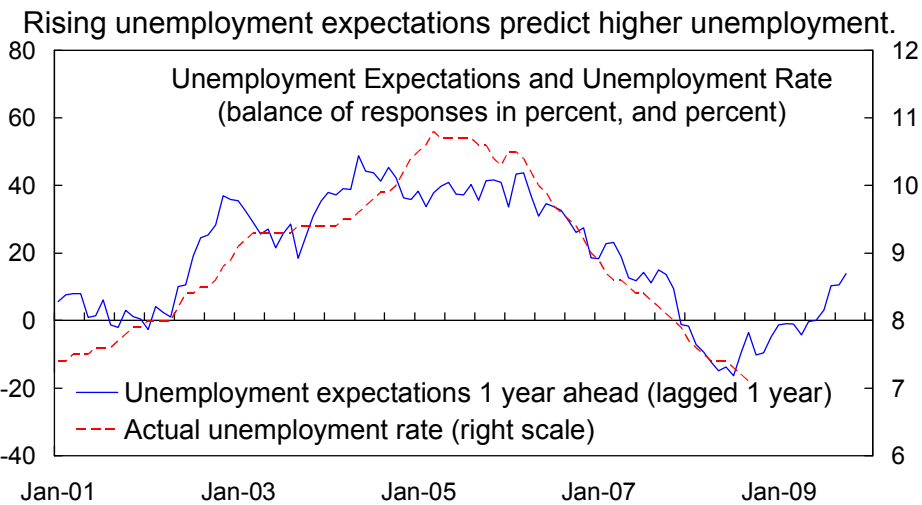
With financial and growth volatility expected to remain elevated in the coming quarters, and with unemployment expectations rising, consumption growth is projected to remain low. In contrast to staff, the authorities expect lower investment growth.

\section{The worsening business outlook - with rapidly shrinking foreign and domestic} order books - will trigger postponement of investment. Investment volatility has traditionally amplified export volatility and the current downturn is no exception. The slowing global manufacturing cycle has sharply curtailed incentives to invest. Investment is projected to fall by $23 / 4$ percent in 2009 , contributing $2 / 3$ percentage point to the decline in output. The fiscal measures approved in fall 2008 (see 937 ) to provide investment incentives will not be able to stem these macroeconomic headwinds.

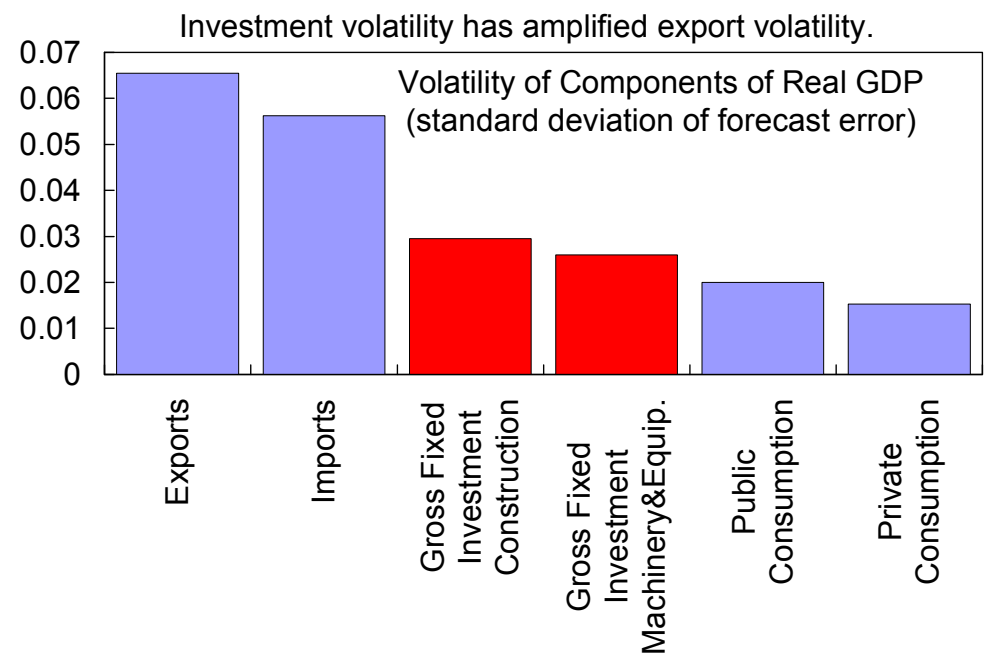
Investment is expected to remain weak in 2010. 


\section{Box 1. Volatility from Global Spillovers Add to German Angst}

\section{After a sustained decline, GDP growth volatility has increased since the mid-nineties, in}

Germany and some other industrial countries. This rise in volatility ${ }^{1 /}$ reflects spillovers of other countries' own idiosyncratic shocks, as the world has become more integrated (with trade in goods and financial assets).

GDP growth volatility is rising in several industrialized countries.
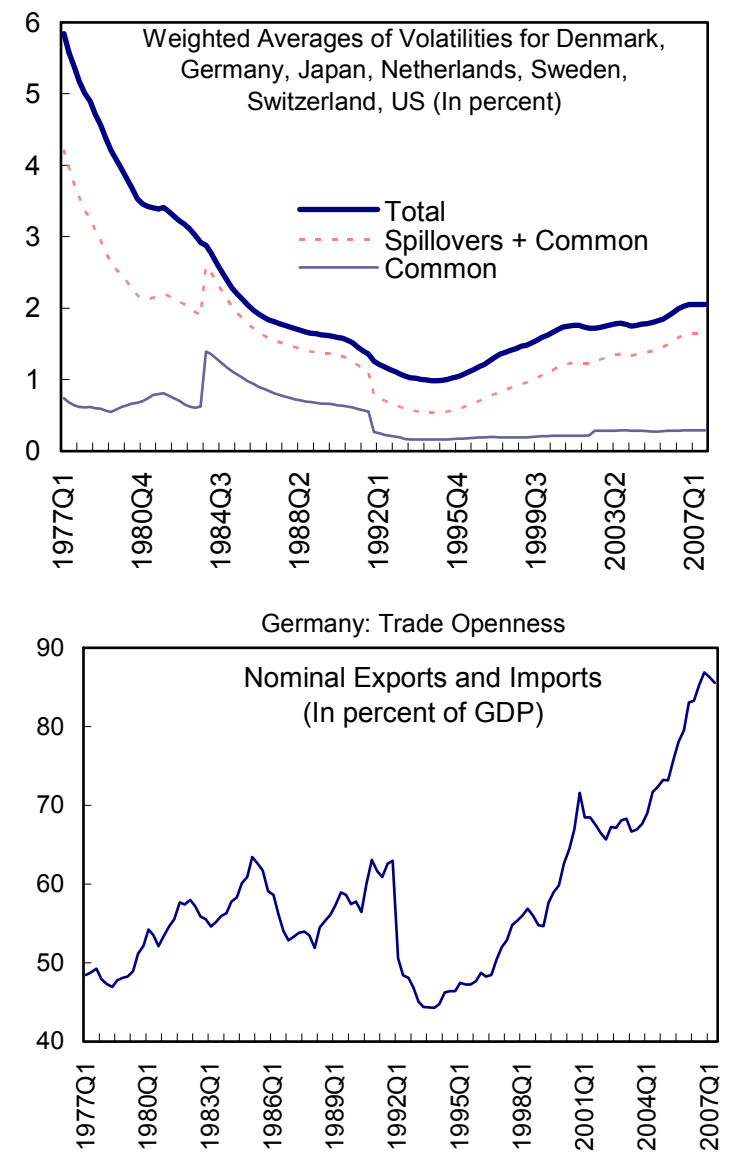

This, in turn, contributed to the slow consumption growth in recent years. Increased GDP volatility and Germany's above-average stock market volatility added to the concerns about tail risks (extreme losses with low probabilities). For precautionary reasons, consumers have preferred to restrain consumption and build buffer-stock savings. During 2002-2007, this effect lowered consumption growth by $1 / 2$ percentage point.

1/ Measured as time-varying variances of growth innovations.
Germany's rising volatility reflects increased spillovers.
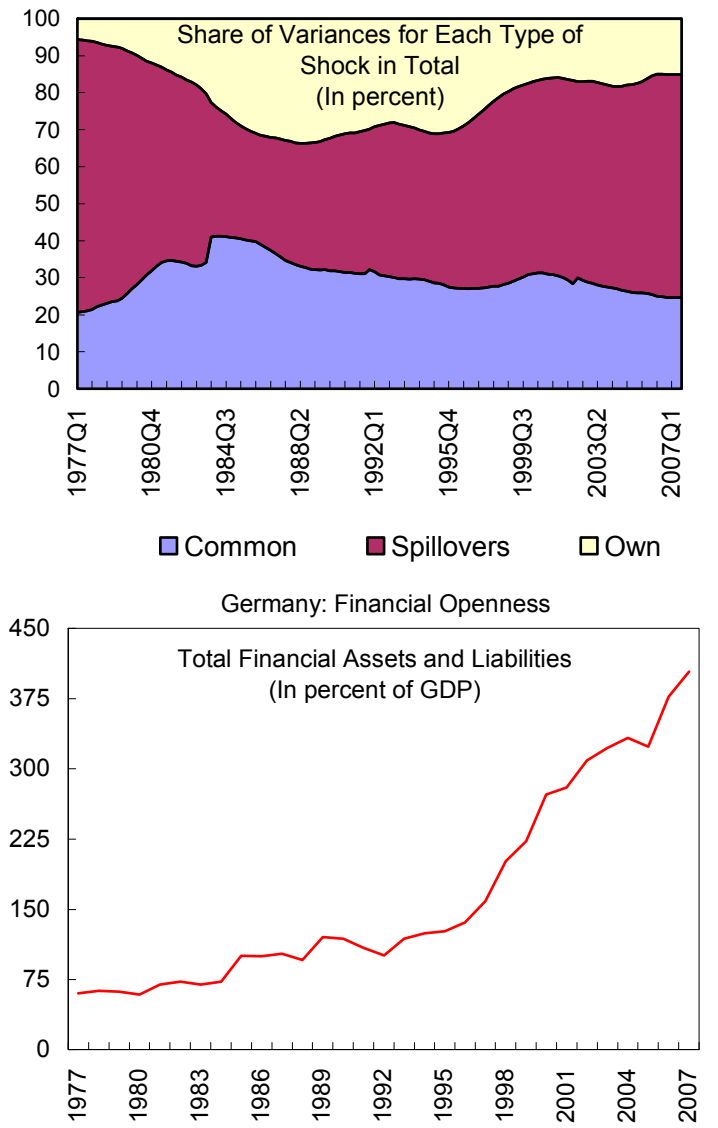

Stock market and GDP volatility have dampened consumption.

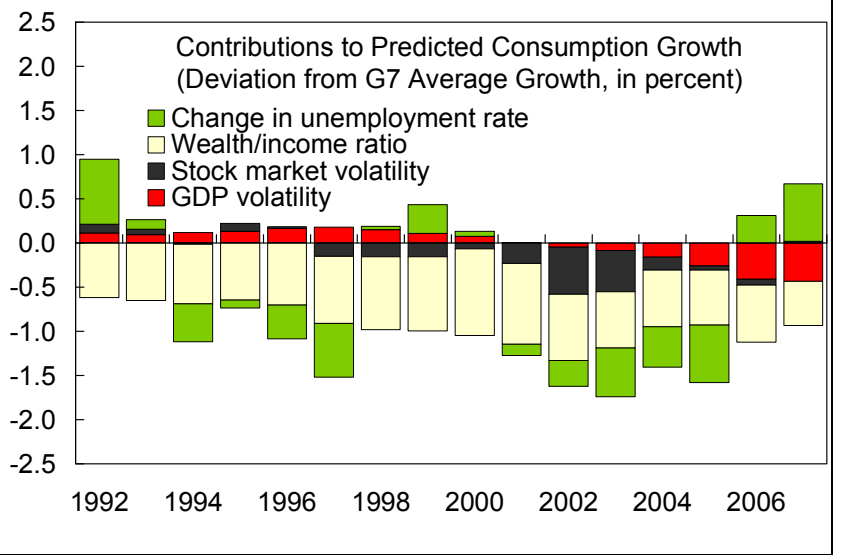




\section{B. Macro-Financial Linkages}

9. These developments in the real economy do not, as yet, reflect a credit crunch, although that may be changing.

Lending standards have tightened somewhat, but more so for large firms than for the small- and medium-sized sector. Yet, overall, bank credit to enterprises has remained relatively robust, declining only slightly in the third quarter of 2008 as demand weakened (Figure 1). Moreover, credit growth has been broad based by type of lending institution. As

Credit standard have tightened, but especially for large enterprises.

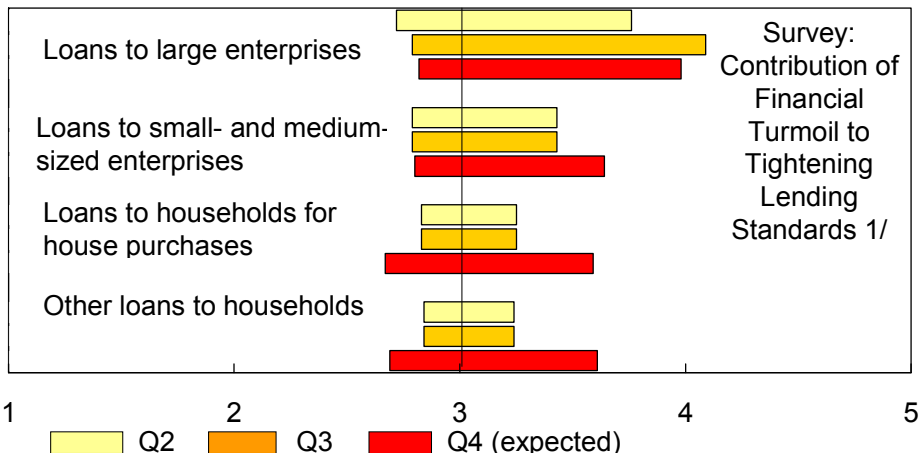

$1 /+/$ - one standard deviation around average. On a scale of 1 (significant easing) to 5 (significant tightening). Sources: Bundesbank; IMF staff calculations. such, limits on bank credit availability have apparently not constrained growth. That may be changing. Staff analysis suggests that banks have been competing on tightening margins, substituting in some cases for the drying up of the corporate bond market. The authorities agree that with higher funding costs and worsening asset quality, a sharper contraction of credit is likely, contributing to a financial accelerator-like process.

\section{The corporate bond market is pricing in significant economic weakening. A}

financial accelerator is evident in corporate bond spreads, which have proved a keen predictor of German GDP growth (Figure 2). The sharp rise in spreads in late-September and early October suggests that the market expects a sizeable growth slowdown along with increased corporate defaults that will keep spreads up. The recent level of spreads predicts a slowing economy through much of 2009. Although this ongoing down cycle started from a point of strength, including in corporate sector balance sheets (Figure 3), the projected GDP

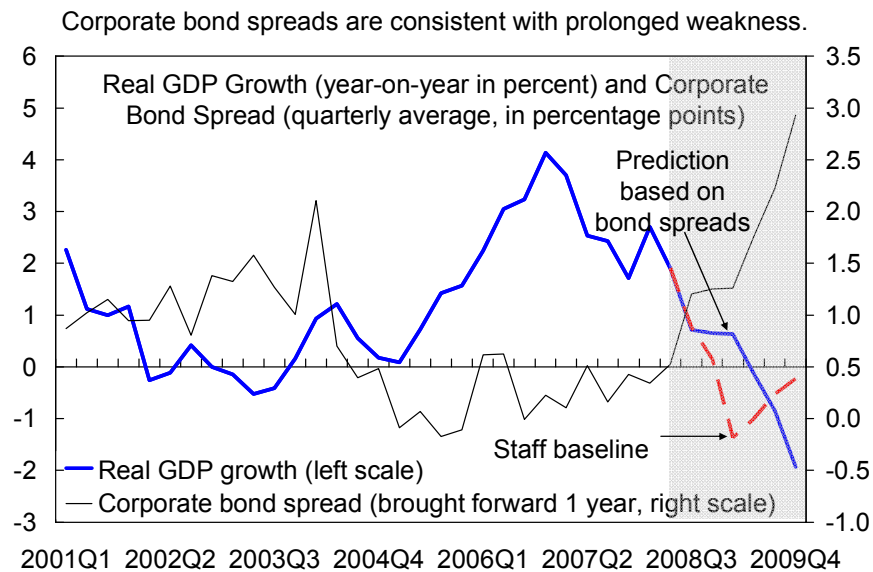


growth rates are lower than in the previous recession. This reflects levels of financial stress (and sentiment) that are significantly worse than during the corresponding phase of the previous downturn. $^{2}$

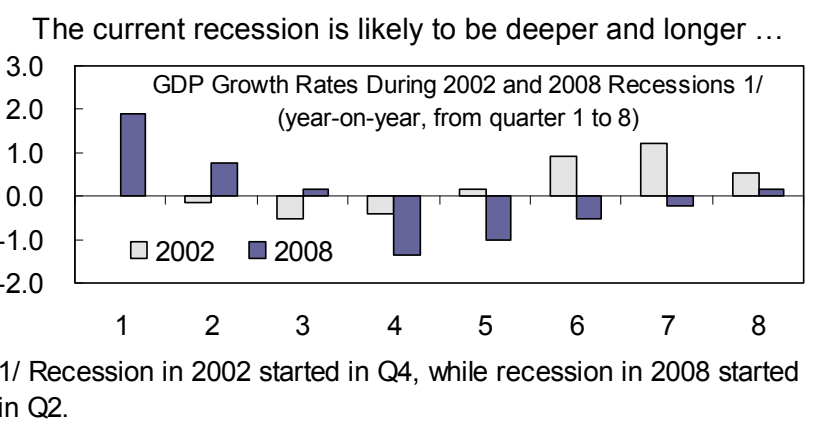

... because of greater stress than in the 2002 recession.

\begin{tabular}{lrr}
\hline & 2002 & 2008 \\
\hline Average annual GDP growth 1/ & 0.2 & 0.0 \\
IFO Business expectations 2/ & 90.3 & 81.4 \\
Corporate spreads 2/ & 1.3 & 3.2 \\
\hline
\end{tabular}

1/ For eight quarters, from the first quarter of the recession. 2/ At the beginning of the third quarter of the recession (October 2008, and April 2003 respectively).

\section{Spillovers}

\section{With its strong international linkages, spillovers into and from Germany are} substantial. The Staff Report for the 2007 Article IV consultation concluded that U.S. and European growth impulses have a significant bearing on German growth, manifest at present in Germany's sharp response to the deceleration in world trade. Growth impulses from Germany were contained in the past but are more prominent now. The authorities agree that an economic slowdown in Germany lowers growth in the rest of Europe, which feeds back to Germany.

\section{Over time, Germany has become more exposed to emerging market shocks, with} implications for ongoing developments. German economic ties to Central Europe are particularly significant: through FDI, trade, and bank subsidiaries (Figure 4). From June 2007, just before the crisis started, to September 2008, German banks' exposure to emerging markets via loans and credit derivatives doubled to about $\$ 450$ billion (Table 2), 4 percent of all German banking assets and 12 percent of all German banks' foreign claims. This expansion occurred at a time when other lenders and investors were retrenching from emerging market assets. A likely scaling back of German banks' exposure to emerging markets would generate cascading spillovers.

\footnotetext{
${ }^{2}$ The 2008 WEO shows that elevated financial stress is associated with longer duration of weakness and substantially-larger output losses.
} 

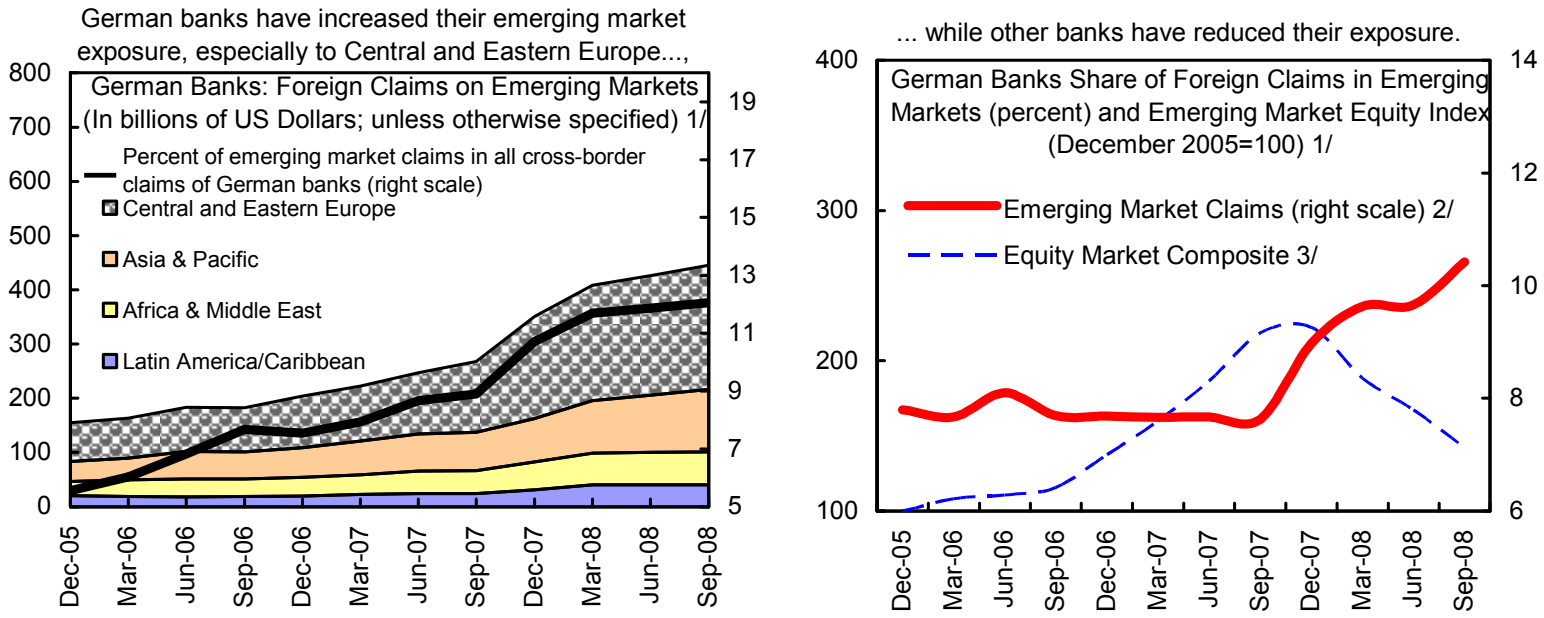

Source: BIS, Bundesbank, ECB, IMF staff calculations.

1/ Consolidated lending statistics, ultimate risk basis, in accordance with BIS reporting standards.

2/ German emerging market claims (in percent of all emerging market claims).

3/ Equity market composite of all emerging market debtor countries. Equity market composite is weighted by GDP at current prices.

\section{Spillovers are also manifest in a heightened concordance of sentiment,}

particularly in an economic downturn. Sentiment in the eurozone becomes more closely aligned when economic prospects worsen. Today, sentiment is more tightly aligned than in the recent past, suggesting that a strong negative reinforcement could continue to hurt growth. German loss of confidence contributes to the contagion of pessimism in the eurozone.

Euro Area sentiments are more closely aligned in economic downturns.
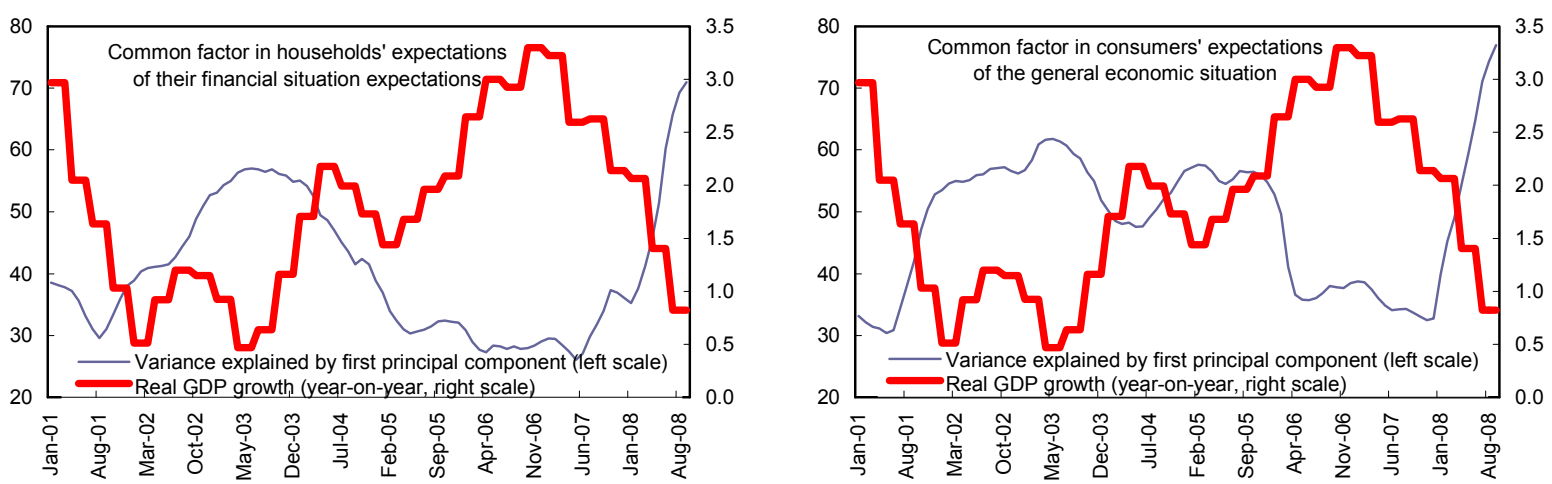

Source: WEO and Globallnsight. 


\section{Inflation Trends}

\section{Inflation has remained contained and is expected to decline fast. Through the}

period of rising food and fuel prices,

German inflation expectations have been solidly anchored. Inflation rose mainly in the headlines, with core inflation

remaining low. There is no evidence that second-round effects threatened at any point. Food and energy prices did not feed into the core categories (Box 2), nor did wages experience an unusual spike. Indeed, real wages dropped sharply when inflation rose. With the moderation of food and fuel prices, inflation is projected to decline from 2.8 percent in 2008 to below 1.0 percent in 2009. Downside risks to growth imply downside risks to inflation.

Wage pressures have remained moderate while productivity growth has slowed.
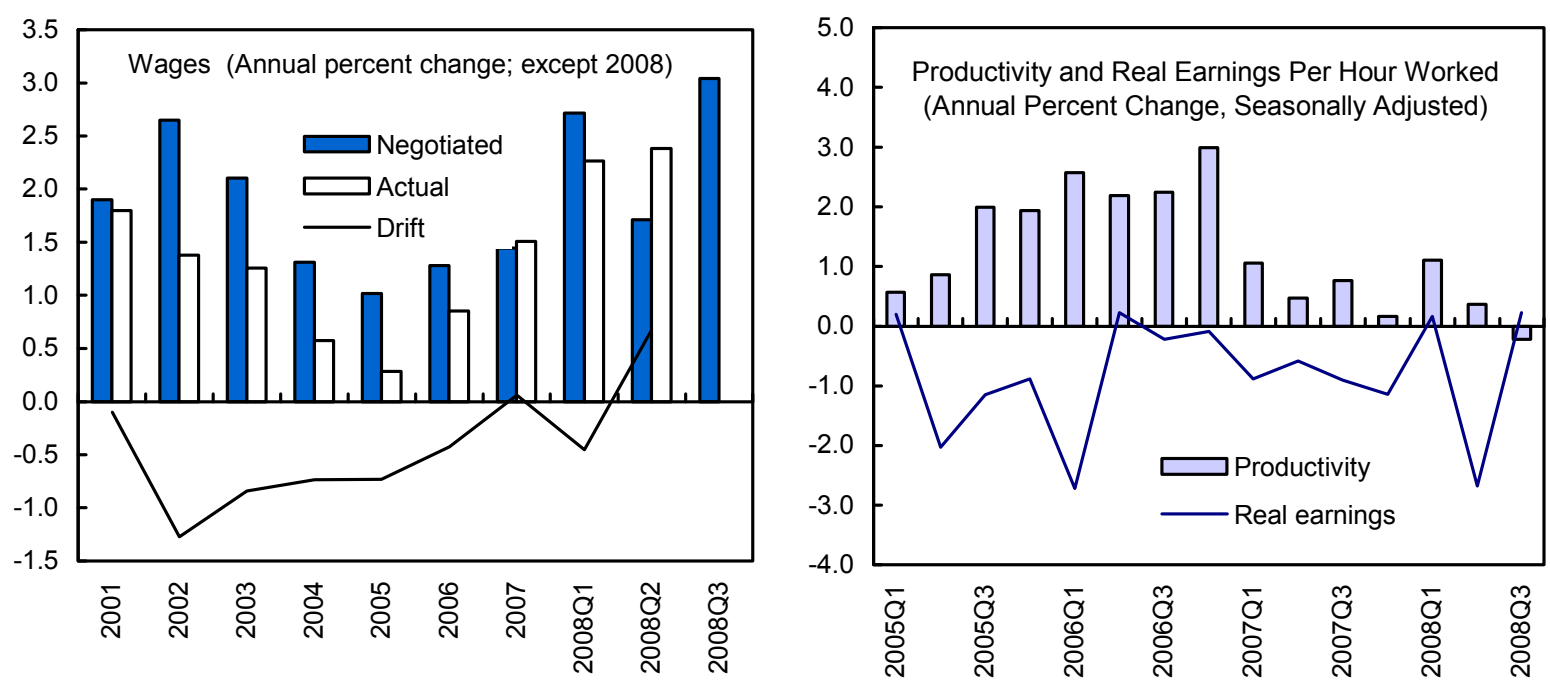

Source: Federal Statistical Office, Federal Labor Office, and Bundesbank.

$1 /$ Wage drift is the difference between actual and negotiated wage increases (monthly basis).

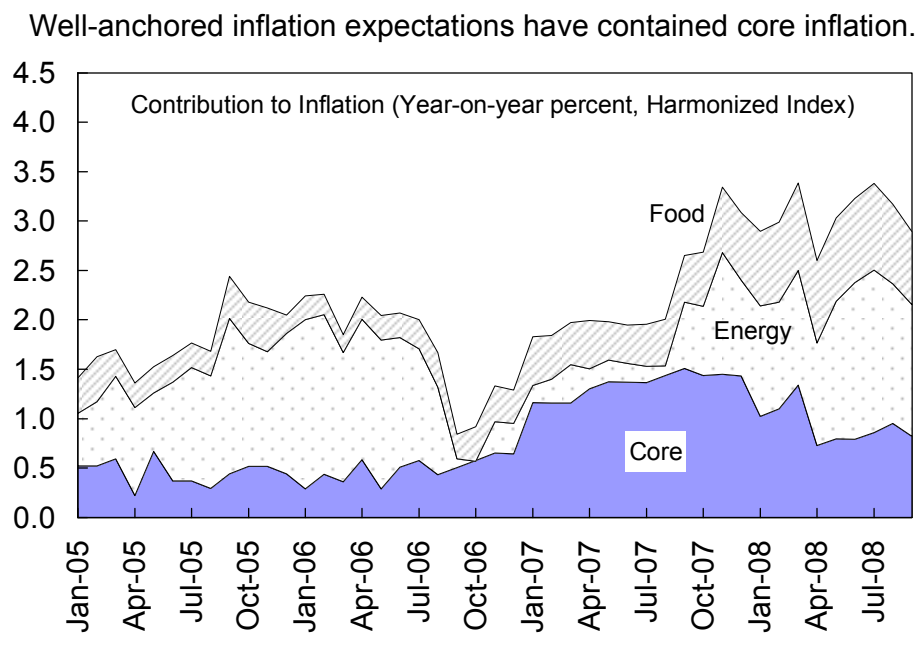




\section{Box 2. Pass Through from Global Fuel and Food Prices}

The influence of global fuel and food prices felt in Germany is broadly in line with the impact observed in other advanced economies. International fuel prices are passed through to domestic commodity prices to a significantly greater extent than are food prices. However, once passed through, food prices have a larger impact on core inflation. The size of these transmission coefficients - the extent of prices transmitted over a year - is consistent with the relatively modest effects that were felt in Germany during the recent run up in food and fuel prices.

\begin{tabular}{|c|c|c|c|c|}
\hline & \multicolumn{2}{|c|}{$\begin{array}{c}\text { International to Domestic } \\
\text { Commodities Prices }\end{array}$} & \multicolumn{2}{|c|}{$\begin{array}{l}\text { Domestic Commodities } \\
\text { Prices to Core Inflation }\end{array}$} \\
\hline & Food & Fuel & Food & Fuel \\
\hline Germany & 0.11 & 0.28 & 0.22 & -0.02 \\
\hline France & 0.05 & 0.24 & 0.61 & 0.02 \\
\hline Italy & 0.07 & 0.20 & 0.43 & -0.03 \\
\hline UK & 0.16 & 0.23 & 0.27 & -0.03 \\
\hline US & 0.09 & 0.38 & 0.00 & 0.01 \\
\hline \multicolumn{5}{|l|}{ Memorandum item } \\
\hline Advanced economies & 0.06 & 0.23 & 0.20 & 0.01 \\
\hline
\end{tabular}

Source: IMF (World Economic Outlook, Fall 2008, Helbling and others)

\section{RISKS TO FINANCIAL STABILITY}

\section{The global financial crisis has highlighted important vulnerabilities of the}

German financial system. Though traditionally conservative, segments of the banking system were exposed to substantial risks. The exposures interacted vigorously with global financial turbulence. As of end-September 2008, Germany accounted for about a quarter of European bank write downs. Of these, about two thirds have been in public or quasi-public sector banks. Two large private banks - Hypo Real Estate and Commerzbank - have sought assistance through the government's financial stabilization package, as discussed below. Looking ahead, the system faces two key vulnerabilities:

- $\quad$ The rollover of wholesale funding: funding conditions remain tight, and bunching of maturing debt obligations creates rollover risk.

- $\quad$ The availability of adequate capital buffers: the low absolute level of capital will be further stressed as profits fall and asset quality worsens with the economic slowdown. 


\begin{tabular}{|c|c|c|c|c|c|c|c|c|c|c|}
\hline \multicolumn{11}{|c|}{$\begin{array}{l}\text { Balance Sheet Magnitude of Financial Crisis } \\
\text { (In billions of U.S. dollars unless noted otherwise) }\end{array}$} \\
\hline & \multirow[t]{2}{*}{$\begin{array}{c}\text { Capital Adequacy } \\
\text { Ratio (CAR) } 1 / \\
\end{array}$} & \multicolumn{2}{|c|}{ Equity } & \multirow[t]{3}{*}{$\begin{array}{c}\text { Total } \\
\text { Assets }\end{array}$} & \multicolumn{3}{|c|}{ Writedowns } & \multicolumn{2}{|c|}{$\begin{array}{c}\text { Capital } \\
\text { Injection }\end{array}$} & $\begin{array}{c}\text { Share of } \\
\text { Public Funds }\end{array}$ \\
\hline & & $\begin{array}{l}\text { In percent } \\
\text { of total } \\
\text { assets } 2 / \\
\end{array}$ & & & Total 3/ & 2007 & $\begin{array}{l}\text { In percent } \\
\text { of equity }\end{array}$ & Total 3/ & 2007 & Total 3/ \\
\hline \multicolumn{10}{|l|}{ Private banks } & \\
\hline Deutsche Bank AG & 11.6 & 1.9 & 56.6 & $2,974.2$ & 10.6 & 3.3 & 18.7 & 6.2 & $\ldots$ & 0.0 \\
\hline Dresdner Bank AG & 13.8 & 3.0 & 21.8 & 736.4 & 3.7 & 1.8 & 16.9 & $\ldots$ & $\ldots$ & ... \\
\hline Commerzbank AG & 10.8 & 2.6 & 23.7 & 907.5 & 2.2 & 0.8 & 9.3 & $\ldots$ & $\ldots$ & ... \\
\hline DZ Bank AG & n.a. & 2.5 & 16.2 & 635.0 & 2.5 & 2.0 & 15.4 & $\ldots$ & $\ldots$ & ... \\
\hline Hypo Real Estate Holding & 9.4 & 2.4 & 2.2 & 90.8 & 1.1 & 0.7 & 51.1 & $\ldots$ & $\ldots$ & ... \\
\hline Postbank AG & 9.2 & 2.6 & 7.8 & 298.8 & 0.8 & 0.8 & 10.2 & $\ldots$ & $\ldots$ & ... \\
\hline IKB Deutsche Industriebank & 12.3 & 2.4 & 1.8 & 75.4 & 15.0 & $\ldots$ & 844.6 & 12.4 & 9.0 & 100.0 \\
\hline \multicolumn{11}{|l|}{ Public banks } \\
\hline Bayerische Landesbank & 11.4 & 3.0 & 18.1 & 611.9 & 7.0 & 4.7 & 38.7 & $\ldots$ & $\ldots$ & .. \\
\hline Landesbank Baden-Württemberg & 9.7 & 0.5 & 15.3 & 652.8 & 4.5 & 2.0 & 29.3 & $\ldots$ & $\ldots$ & ... \\
\hline WestLB & 9.1 & 1.5 & 6.5 & 421.8 & 4.3 & 4.1 & 66.0 & 7.3 & $\ldots$ & 68.5 \\
\hline HSH Nordbank AG & 10 & 3.1 & 9.2 & 296.7 & 3.6 & 2.0 & 39.0 & 1.9 & $\ldots$ & 76.2 \\
\hline Landesbank Sachsen AG & 9.9 & 1.7 & 2.1 & 125.2 & 2.4 & 2.4 & 115.3 & 0.4 & 0.4 & 0.0 \\
\hline Nord/LB & 9.5 & 3.1 & 9.2 & 296.7 & 0.6 & 0.3 & 6.5 & $\ldots$ & $\ldots$ & .. \\
\hline Helaba & 11.4 & 2.8 & 7.2 & 255.8 & 0.5 & 0.3 & 6.9 & $\ldots$ & $\ldots$ & ... \\
\hline Total & $\ldots$ & $\ldots$ & 197.8 & $8,378.8$ & 58.8 & 25.2 & 29.7 & 28.2 & 9.4 & ... \\
\hline as percent of global & $\ldots$ & $\ldots$ & 4.4 & 10.2 & 11.3 & 11.8 & $\ldots$ & 7.4 & 16.7 & ... \\
\hline as percent of Europe & $\ldots$ & $\ldots$ & 9.0 & 16.2 & 22.3 & 24.2 & $\ldots$ & 14.5 & 30.4 & ... \\
\hline \multicolumn{11}{|l|}{ Memorandum items: } \\
\hline Global 4/5/ & $\ldots$ & 5.4 & $4,466.7$ & $81,997.2$ & 522.5 & 213.1 & 11.7 & 380 & 56.4 & ... \\
\hline of which: Americas & 13.6 & 9.2 & $1,474.8$ & $16,117.2$ & 263.3 & 104.2 & 17.9 & 194.5 & 30.9 & ... \\
\hline of which: Europe & 13.9 & 4.3 & $2,197.1$ & $51,569.1$ & 235.1 & 97.9 & 10.7 & 163.3 & 25.6 & ... \\
\hline of which: Germany & 11.4 & 2.2 & 207.1 & $11,305.9$ & 58.8 & 25.2 & 28.4 & 28.2 & 9.4 & ... \\
\hline of which: Asia & 14.2 & 5.2 & 904.9 & $17,314.8$ & 24.1 & 11.1 & 2.7 & 22.2 & 0.0 & ... \\
\hline
\end{tabular}

Source: Annual Reports, Bloomberg, Bankscope, Moody's KMV, The Banker, IFS statistics, IMF staff estimates.

$1 /$ Bank regulatory capital to risk-weighted assets (CAR) according to revised Basel Capital Accord.

2/ At end-2007, in percent of total assets.

3/ Since start of the crisis in June 2007 until September 2008

$4 /$ Includes only commercial banks.

$5 /$ Median CAR values in the respective region.

\section{A. Funding Pressures}

\section{Traditionally reliant on a strong retail depositor base, German banks had}

\section{increased their demand for wholesale}

funding. This was so especially over the years 2004-2007. Starting in mid2007 , but especially since early 2008 , these funding sources have contracted sharply. The continued risk that market liquidity will not be rolled over presents an important short-term source of vulnerability. These concerns were especially manifest in the case of Hypo Real Estate.

\section{Funding pressures are} manifest even in the highly-secure

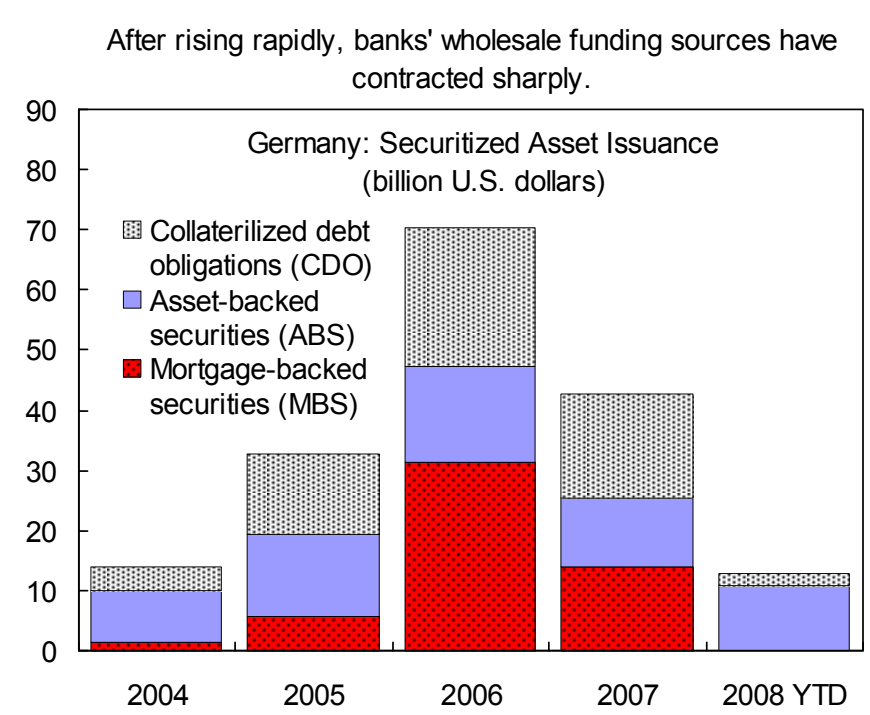
books (with loan-to-value ratios in the 60-80 percent range) or by loans to the public sector, German covered bonds have been considered almost as safe as Bunds. However, since the 
spring of 2008, spreads on these bonds have tended to increase, and, following the sharp rise in September, have stabilized at historically-high levels. Trading in the secondary Pfandbrief market has nearly halted since early September, as bondholders are apparently using their Pfandbrief positions as collateral for receiving liquidity from the central bank. Planned issues of covered bonds have been cancelled or cut in volume as the primary market demand has shrunk. Wholesale investors apparently prefer the large ongoing and expected issues of directly government-guaranteed debt.

Even in the covered bond market, liquidity has dried up.

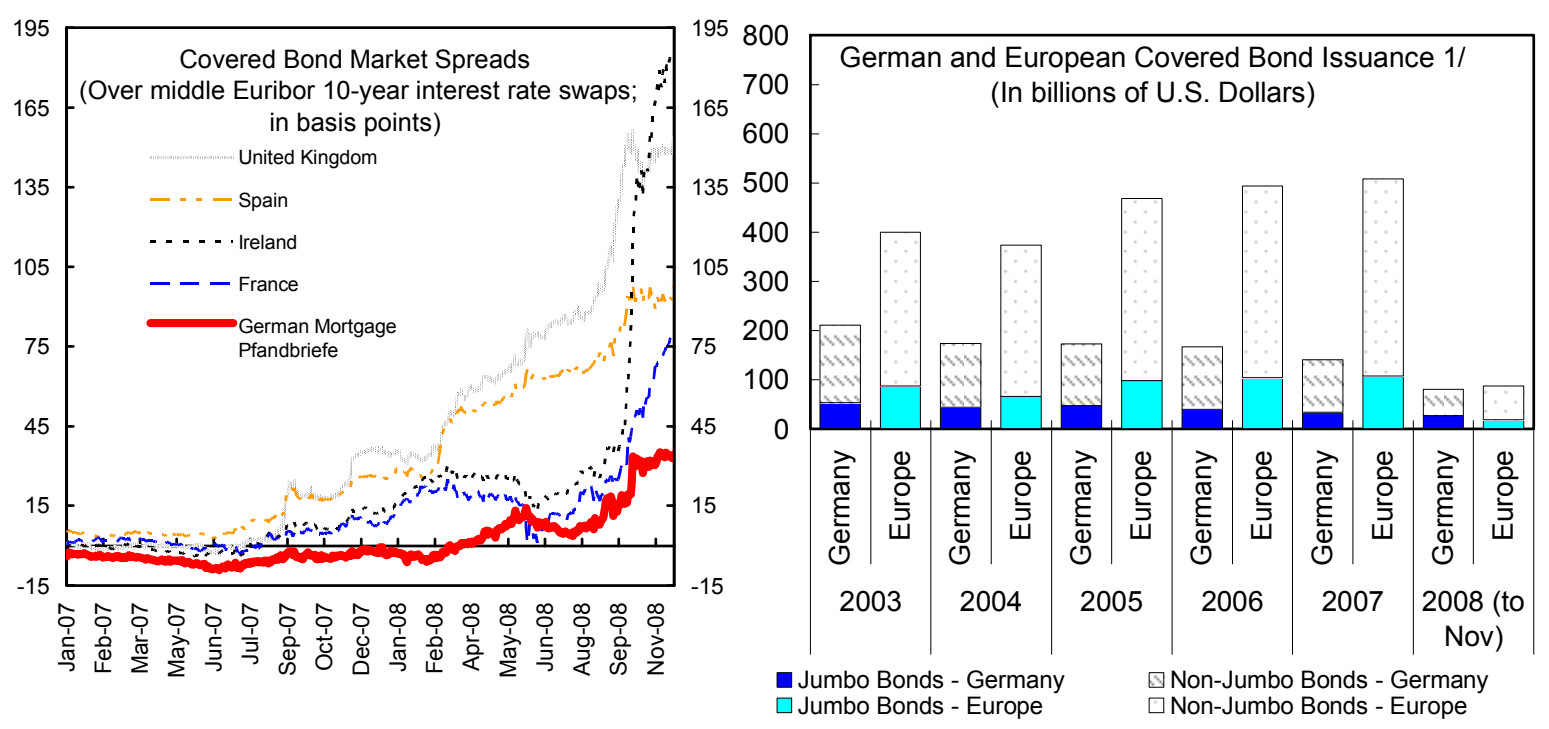

Source: Datastream; and IMF staff estimates and calculations.

$1 /$ Data for non-Jumbo bonds for the second half of 2008 not available.

\section{B. Capital Adequacy}

\section{Though banks are in compliance with their regulatory capital requirements,} their high leverage ratios and falling profits will add to stress. At about $4 \frac{1}{2}$ percent, the equity-to-consolidated assets ratio of the German banking system is low even by European standards (Tables 3 and 4). The gap between the riskweighted capital ratio and the leverage ratio is particularly large for the big commercial banks, the Landesbanken, and the mortgage banks. This reflects the favorable risk weighting of their assets (including portfolios of derivatives instruments) under current Private banks' profitability has fallen.

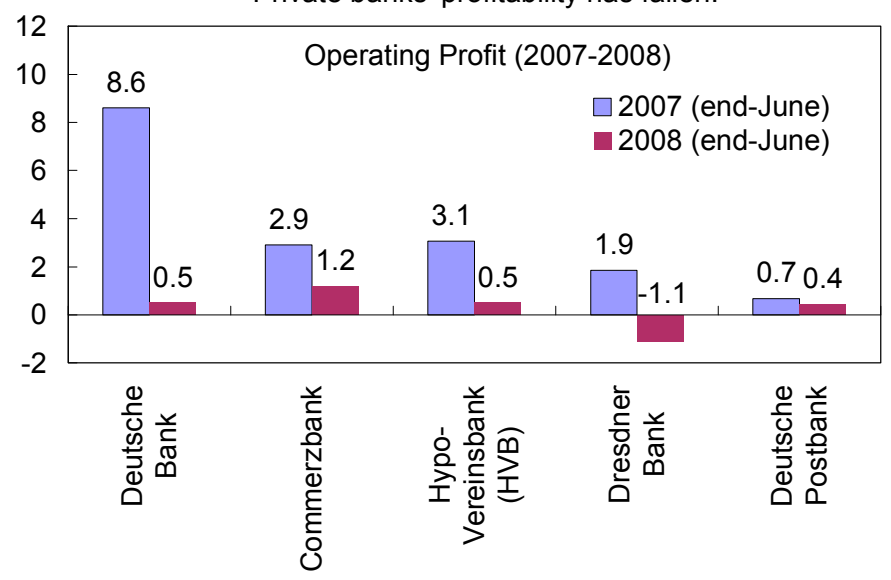
regulatory guidelines. Moreover, bank profits had fallen sharply by mid-2008 and, with the 
economic downturn, are likely to remain low in 2009. As asset quality worsens, and the need for additional provisioning increases, so will the need for additional capital.

Banking Sector - Performance and Soundness Indicators: Selected Countries, end-2007 1/

(In percent)

\begin{tabular}{|c|c|c|c|c|c|c|c|}
\hline & France & Italy 2/ & Japan & Spain 3/ & UK 4/ & US & Germany \\
\hline Bank Regulatory Capital to Risk-Weighted Assets & 10.1 & 10.4 & 12.9 & 11.4 & 12.6 & 12.8 & 12.9 \\
\hline Bank Capital to Assets & 5.5 & 7.7 & 5.0 & 7.0 & 7.9 & 10.3 & 4.3 \\
\hline Bank Nonperforming Loans to Total Loans & 2.7 & 4.8 & 1.5 & 0.7 & 0.9 & 1.4 & 2.7 \\
\hline Bank Provisions to Nonperforming Loans & 61.4 & 49.5 & 28.8 & 204.8 & ... & 93.1 & 77.3 \\
\hline Bank Return on Assets & 0.4 & 0.7 & 0.2 & 1.1 & 0.4 & 0.8 & 0.2 \\
\hline Bank Return on Equity & 9.8 & 9.7 & 3.2 & 19.9 & 6.2 & 7.8 & 4.7 \\
\hline Loan-Deposit Ratio & 58.6 & 126.5 & 75.7 & 102.7 & 71.4 & 104.1 & 66.0 \\
\hline Short-term Funding Ratio & 26.6 & 8.4 & 7.5 & 5.8 & 23.5 & 19.2 & 30.7 \\
\hline Tier 1 Capital to Total Capital & 63.8 & 82.1 & 80.4 & 69.7 & 61.1 & 88.4 & 68.6 \\
\hline Off-balance Sheet Items to Total Liabilities & 25.2 & 10.9 & 2.8 & 24.9 & 54.1 & 192.9 & 16.0 \\
\hline
\end{tabular}

Sources: National authorities, Bankscope, Moody's KMV, IMF staff estimates.

$1 /$ The sum of ratios including all asset or liabilities can sum up to greater than unity due to the aggregation of averages.

2/ Consolidated reports for banking groups and individual reports for banks not belong to groups.

3/ Bank Nonperforming Loans to Total Loans: Doubtful exposures to other resident sectors over total lending to other resident sectors; Bank Provisions to Nonperforming Loans: allowances and provisions to doubtful exposures.

4/ Bank Provisions to Nonperforming Loans: data for large banking groups; Bank Return on Assets: before tax.

\section{The need for more capital is also dictated by the heightened financial volatility.}

Since the start of the crisis in July 2007, market assessments of the probabilities of default on bank debt have increased (Figure 2). This has been a function primarily of increased uncertainty regarding the quality of assets amid deteriorating credit conditions reflected in the low market valuation of German bank relative to European peers. As a consequence, a large share of German banking assets has moved into sub-investment-grade credit ratings categories while overall default risk has increased.
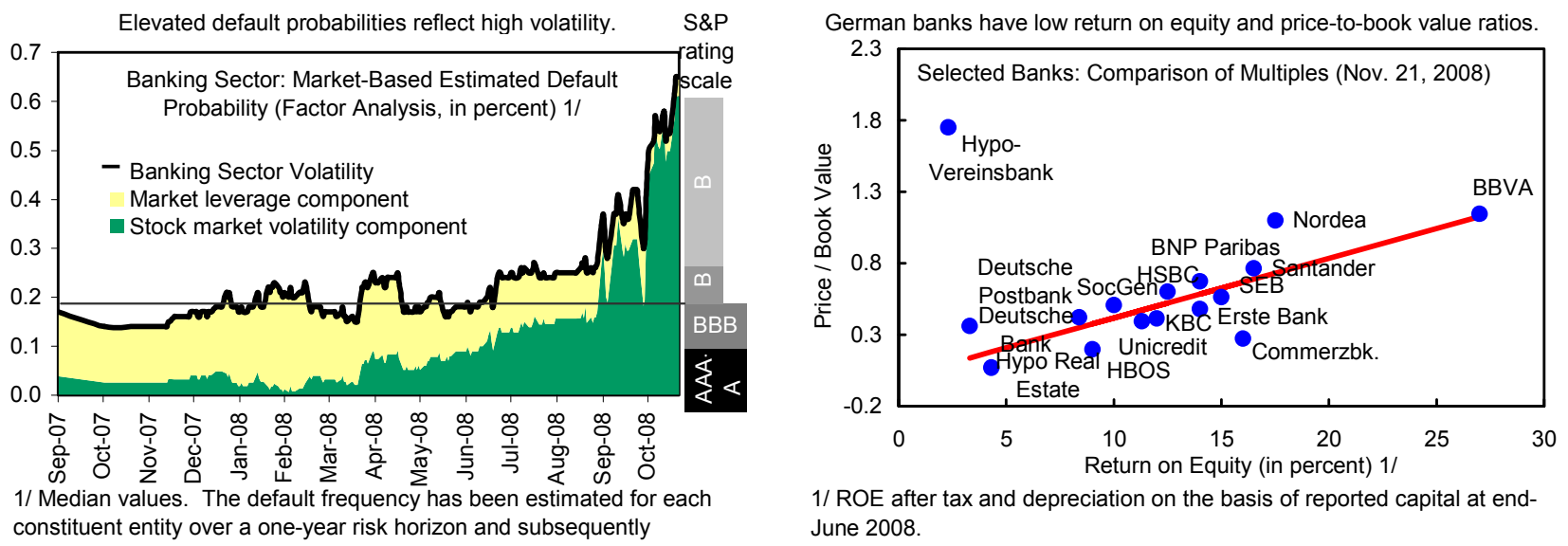

$1 /$ ROE after tax and depreciation on the basis of reported capital at endJune 2008.

Source: Reuters-Thomson, Datastream, Bloomberg, and IMF staff estimates. 
Implied ratings of banks have fallen sharply.

Rating Breakdown of Banking Sector

(Asset weighted, Standard \& Poor's rating scale, in percent)

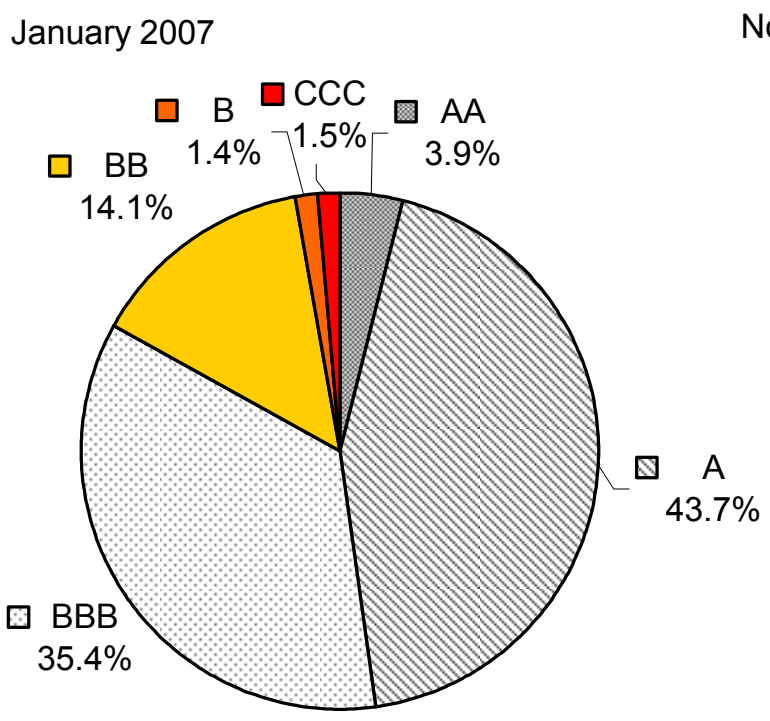

Share of investment grade-rated banks: $84 \%$
November 2008

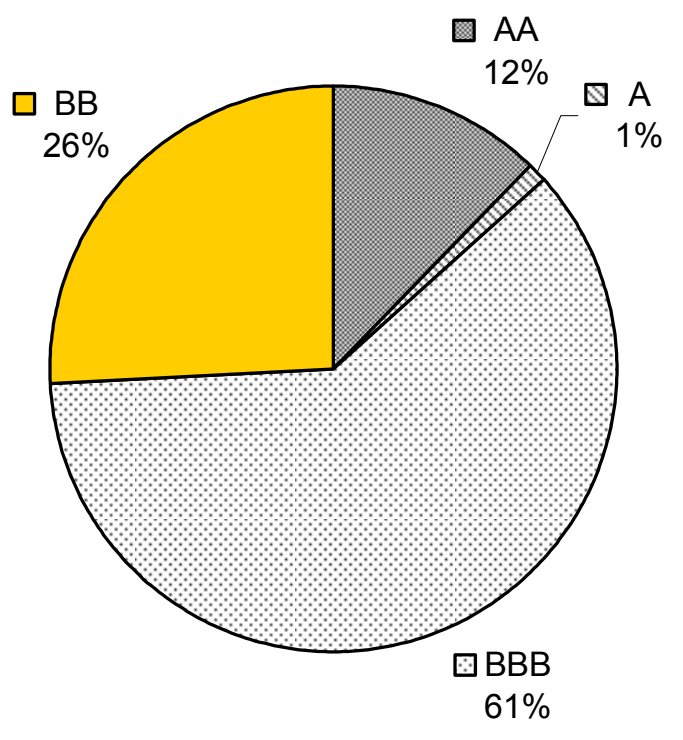

Share of investment grade-rated banks: $74 \%$

20. Looking ahead, the economic slowdown will generate further pressures. The relatively low debt ratios of companies and households and the significant role of retail deposits in the funding of banks will continue to cushion the impact of the current shocks. The low debt ratios have been accompanied by modest increases in equity prices and flat house prices. Despite that, the nonfinancial sector is now more broadly affected than during the earlier stages of the crisis. The borrowing costs for nonfinancial corporates, especially for the lower-quality borrowers have increased sharply as perceptions of default probabilities have increased. This has occurred across various sub-sectors (construction, automobiles, engineering, and chemicals) and not only for low-grade entities, as would be expected during a slowdown, but also for highly-rated corporates. 
Advanced Countries and Germany: Debt Positions and Asset Price Developments (In percent)
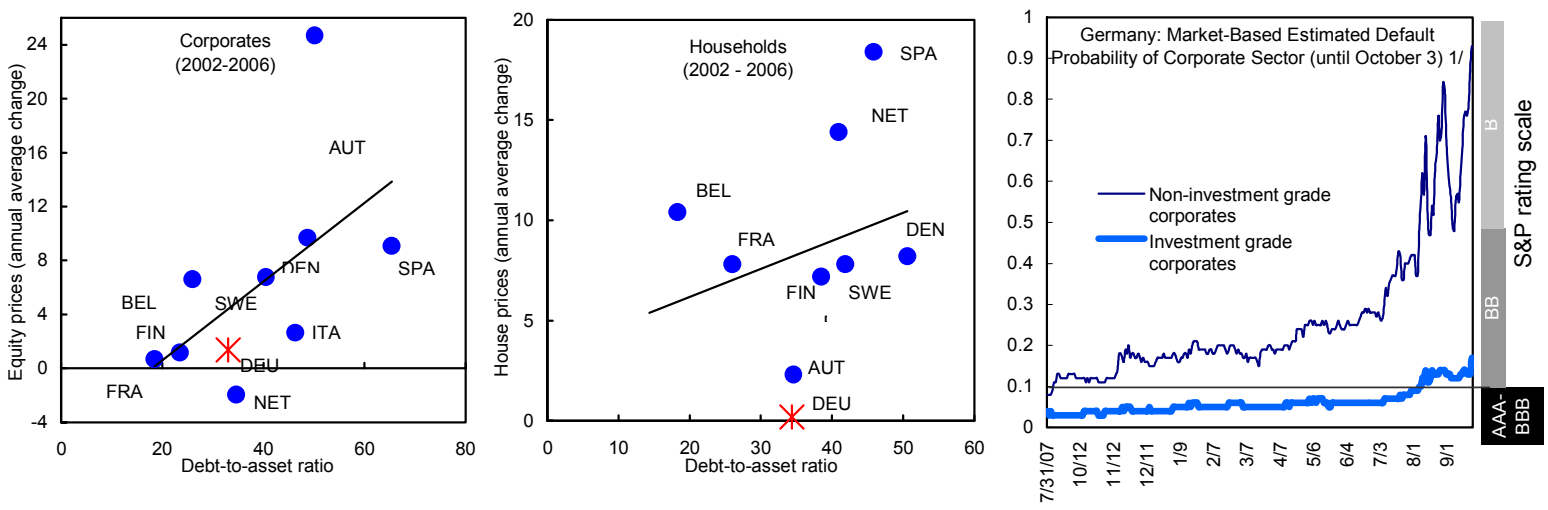

Source: Regional Economic Outlook, Europe, Fall 2008,Reuters-Thomson, Datastream, Bloomberg, and IMF staff estimates.

1/ Median values. Distinction based on investment and non-investmentgrade rating assigned by Standard\&Poor's. The default frequency has been estimated for each constituent entity over a one-year risk horizon and subsequently aggregated.

\section{RESPONSE TO THE CRISIS}

\section{A. The Stabilization Package}

21. The Financial Market Stabilization Fund (FMSF) has been vital to shielding the financial sector. The FMSF is the conduit for a $€ 100$ billion package available until December $31,2009 .{ }^{3}$ It includes $€ 20$ billion as provision to back up guarantees of up to $€ 400$ billion to secure market borrowings by banks and up to $€ 80$ billion for capital injections or purchase of assets. The envelope of available guarantees is expected to cover upcoming funding needs. The guarantees for select newly issued debt securities and liabilities (with maturities of up to 36 months) will complement the political commitment to protect household depositors and together these should alleviate rollover and funding risks. The capital injections address the banks' need for capital and should ease solvency concerns.

22. As elsewhere, the package has helped calm markets. The improvement in sentiment is reflected in the decline in banks' CDS spreads, which are now off their peaks, although still at elevated levels. In the short run, the guarantees to creditors are crucial to the continued thawing of funding and interbank markets. Hypo Real Estate has drawn on the guarantee window. Commerzbank is to receive capital support in the form of a silent participation and can call on guarantees. Several Landesbanken have publicly expressed interest in assistance from the FMSF.

\footnotetext{
${ }^{3}$ Based on a decision by the EU Commission, a review is required after six months since enactment. The Länder will share 35 percent of the costs (although capped at $€ 7.7$ billion) and, in addition, will absorb the costs associated with the Landesbanken.
} 
23. The German package is sizeable but the approach, unlike in the U.S. and the U.K., has thus far been more hands off. The authorities are relying on banks' assessments in seeking public assistance. They indicated that they are not yet ready to implement a more proactive approach, as suggested by staff. The conditionality associated with the FMSF's assistance appears milder than in the U.K. but more stringent than in the U.S. Also, the German authorities are able to provide Tier I capital through silent participations that do not dilute existing shareholder positions. This approach appears appropriate based on the banks' current solvency position, but might need to be revised and tightened, on a case-by-case basis, to more aggressively dilute shareholders if significant additional losses are identified. The challenge for the authorities will be to support viable banks while providing incentives for the recourse to private capital markets. Regular financial reporting and audits will provide transparency and accountability. ${ }^{4}$

24. The proactive restructuring of the Landesbanken requires early attention. The economic role of the Landesbanken is in question, highlighted by their investments in imprudent ventures. Moreover, the financial crisis has revealed the serious risks - to their viability and, thereby, to systemic stability — associated with their wholesale funding approach. Downsizing these banks, separating them into "good" banks and "bad" banks, and incorporating the "good" banks (to enable the introduction of private capital) should be among the options for their restructuring. Proposals to combine these troubled institutions need careful assessment since larger troubled banks would pose even greater systemic problems. The authorities agree that the Landesbanken must be restructured but believe that the Lander, as principal owners, must take the initiative. Staff recommended that SoFFin could work with the Landesbanken and their owners to break the impasse.

\section{B. Strengthening the Safety Net}

25. Reforms to achieve early intervention and effective bank resolution are essential. The German bank resolution framework is not in line with sound international practices or the recommendation of the Financial Stability Forum that calls for a broad range of resolution tools. Banks play a key role in the economy, and run specific risks that may materialize quickly with a major impact on the economy. In return, banks should be subject to a special resolution regime, typically including the ability for the authorities to take a range of quick and decisive actions concerning failing banks that would permit limiting shareholders' rights. The German legal framework is constrained in this regard by the general corporate legal regime, which is more respectful of property rights. As a consequence, bank resolution, often

\footnotetext{
${ }^{4}$ Speedy review of individual cases by DG Competition of the European Commission will provide needed legal certainty to transactions.
} 
under the leadership of the associations, may take longer and possibly result in declining asset values and delays in depositor access to their funds.

26. The authorities have taken a first step in this direction and are exploring further enhancements. The financial stabilization package allows for speedy shareholder dilution in recapitalizations. These powers need to be broadened beyond the 50 percent dilution currently allowed for the FMSF. The deposit protection scheme for cooperative banks, where shareholder voting rights are less of a concern, has successfully been used to fund a full range of resolution tools to deal with its financially distressed/insolvent member banks. The authorities are exploring ways to strengthen the bank resolution framework.

\section{The authorities are considering broader changes to deposit insurance, in concert} with recent European initiatives. A sound deposit insurance framework is a key component of the financial safety net. The recent crisis revealed important limitations of the patchwork of statutory and private schemes, which offer differing levels of protection to depositors (Box 3).

- $\quad$ The lack of public awareness about relevant coverage and features (including financial strength and the legal obligations of the schemes) created incentives for sudden movements of deposits between different segments of the banking sector.

- $\quad$ Coverage under the statutory schemes (€20,000; 0.7 times GDP per capita) is low by international comparison and includes a coinsurance element that risked undermining depositor confidence.

- $\quad$ The time limits for depositor reimbursements under the statutory schemes are rather long and prevent prompt access to deposits, further contributing to uncertainty. 


\section{Box 3. Germany's Fragmented Deposit Protection ${ }^{1}$}

Commercial banks: statutory scheme - The coverage provided for deposits in private commercial banks under the statutory scheme is low by international comparison ( 0.7 times GDP per capita), and includes an element of coinsurance (up to $€ 20,000 / 90$ percent of deposits per depositor and bank). Reimbursement of deposits is initiated by a declaration by BaFin and should be completed within 3 months (an extension for another 3 months is possible).

Commercial banks: private scheme - The Bankers' Association offers for its member banks additional coverage amounting to 30 percent of the bank's capital per depositor, constituting a de facto full compensation scheme (though not legally enforceable by depositors). While resources have been built up reportedly amounting to $€ 4.6$ billion in September 2008, the parameters for ex post burdensharing arrangements among banks in times of financial turmoil and heavy claims are not clear.

Savings banks (Sparkassen) and Landesbanken - Partial ex ante funding (risk-based) is built up under regional arrangements and coupled with additional ex post burden-sharing provisions (including contributions from the local authorities that sponsor the institution) to protect the institutions in their entirety. Further support is provided under the inter-regional arrangement and master arrangement, if needed (without legal obligation). Public banks (other than savings banks and Landesbanken) have their own statutory and private schemes administered by the Association of German Public Sector Banks.

Cooperative banks (Volks- und Raiffeisenbanken) - The protection scheme run by the National Association of German Cooperative Banks is intended to protect cooperative banks in their entirety. Ex ante funding (risk-based) is complemented by limited guarantees. When called upon, resources may be committed for broad purposes but there is no legal obligation to provide assistance. The Association takes the lead in resolving failed member banks, typically through purchase-and-assumption transactions or mergers.

1/ While financial statements for the various schemes must be submitted to BaFin and the Bundesbank, no information on their actual financial strength is made publicly available.

\section{A step forward would be the creation of a single fund for the statutory deposit} insurance coverage that spans the pillars of the German banking sector. This fund would replace the funds run by the various associations. It would provide for unified terms of coverage, thereby enhancing transparency and legal certainty for depositors. Such a fund would be more diversified in its risks than the existing funds and it could be tapped to facilitate resolutions of banks. More ex ante funding of deposit insurance is preferable to the current predominantly ex post practice that in an economic downturn will be procyclical. The authorities indicated that there is a clear need for change, but the political will for such change is limited. Evolving EU rules should guide policies with respect to deposit insurance. This would entail increasing minimum coverage under the statutory schemes (initially to 
$€ 50,000$ and possibly to $€ 100,000$ when adopted as the EU minimum) and procedures put in place to facilitate prompt access to insured deposits. In light of the experience with Northern Rock and subsequent removal of coinsurance in the U.K., Estonia, and others, the authorities should remove the coinsurance feature of the statutory schemes. Supplementary coverage could be allowed provided it did not compromise transparency.

\section{Prudential Regulation and Supervision}

\section{Beyond the immediate crisis response, lessons from the crisis call for} enhancements to the regulatory and supervisory framework. The authorities are taking steps to implement Pillar II of Basel II and to introduce recommendations that respond to the recent crisis. In this regard, the consultation paper on the European Capital Requirements Directive (CRD) has identified three salient issues: a college of supervisors for cross-border banks, capital requirements for securitization, and binding limits on interbank exposures. The enhanced capital requirements for securitization will force German banks, some of whom have recently engaged heavily in these transactions, to face their responsibilities and also to leave traces in their prudential returns to more easily draw supervisors' attention. Additional recommendations by the Financial Stability Forum (FSF) that will require attention include: the review of banks' liquidity contingency plans, sharing with other countries' authorities of their crisis management experience, and consistent approaches to liquidity for cross border banks. The authorities indicated that salaries at BaFin are at the lower end of supervisory compensation in Europe, which could impede acquiring the expertise to oversee the complex risks and the new challenges.

30. At the same time, the case for a tighter bank regulatory and supervisory process has become more compelling. To respond promptly to problem situations, supervisors have a heightened need for information on the current status of bank soundness. As such, greater consolidation of regulatory and supervisory resources could yield significant benefits. This implies:

- Significantly reduced reliance on external auditors. Such reliance creates the scope for significant delays in identifying financial stress.

- $\quad$ Prudential regulation and supervision should be linked to a system of macrosurveillance and stability analysis.

- $\quad$ As recommended by the FSF, Bundesbank would need ready access to firm level supervisory information to facilitate their emergency liquidity support activities.

31. Alternative structural approaches could improve supervision. Should all prudential oversight be placed under the authority of the Bundesbank, as provider of liquidity to the banking sector, its operational independence would need to be assured. Another option would be to place all supervision in BaFin, but here compensation limits could become 
problematic, especially since the specialized skills for the implementation of Basel II are in scarce supply. Under either option, the authorities may wish to also explore the "twin peaks" model whereby prudential and market conduct supervision and regulation of the financial sector are placed in separate agencies. This model is being used by the Dutch authorities. The authorities indicated that they plan to retain the "integrated supervisor" model but intend to undertake a more detailed review by March 2009.

\section{Competitiveness}

\section{The authorities agree that Germany enjoys a small competitiveness advantage,} though the CGER methodology results in divergent assessments. It is customary to take a simple average of the three approaches, which gives a competitiveness advantage (margin) of $5 \frac{1}{2}$ percent. That is similar to the assessment of the

\begin{tabular}{lrrr}
\hline \multicolumn{4}{c}{ Germany: Competitiveness Assessment } \\
\cline { 2 - 4 } & $\begin{array}{r}\text { Approach } \\
\text { balances }\end{array}$ & $\begin{array}{r}\text { External } \\
\text { Sustainability }\end{array}$ & $\begin{array}{r}\text { Equilibrium Real } \\
\text { Exchange Rate }\end{array}$ \\
\hline Current account norm & 4.0 & 0.6 & $\ldots$ \\
Underlying current account balance/ & 6.5 & 6.5 & $\ldots$ \\
Current account projection for 2013 1/ & & & $\ldots$ \\
Competitiveness gap & & -15 & 2 \\
\hline 1/ See Table 5. & -4 & &
\end{tabular}
staff's view best reflects German conditions. Under this approach, a country's savingsinvestment balance is judged against an equilibrium computed using several norms, which include estimates of long-term societal preferences for precautionary savings and demographic factors. By this measure, the competitiveness advantage is about 4 percent. In contrast, by the so-called "external sustainability" approach, the "equilibrium"

Germany's current account surplus reflects a high equilibrium norm. current account surplus is that needed to maintain net foreign assets at the current level. But since Germans evidently prefer to save to accumulate foreign assets, as the macro-balances approach recognizes, the external sustainability approach overstates the competitiveness advantage.

\section{The equilibrium real exchange rate} (ERER) measure, which reflects a disadvantage, may also not be an appropriate measure for Germany. The ERER measures competitiveness using the CPI-based real exchange rate (REER). While German inflation has moved with that in the eurozone, German wages have fallen in real terms and, in particular, relative to major European countries. With

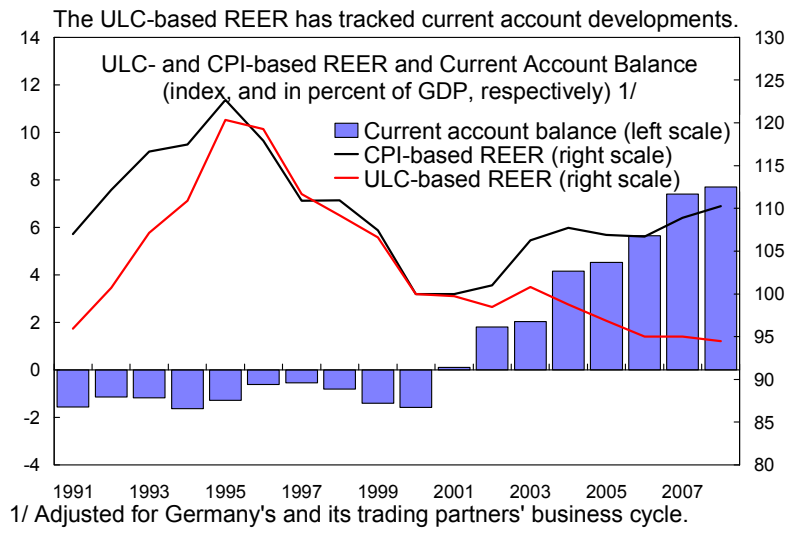


85 percent of German exports in the manufacturing industry, the manufacturing unit labor cost (ULC)-based real exchange rate index better tracks competitiveness than the CPI-based one. Since 2003, the current account balance has steadily improved consistent with the continued real depreciation in the ULC-based real exchange rate, while the CPI-based REER has appreciated. Germany's increasing gap between the CPI- and ULC-based real exchange rates is particularly noteworthy when compared to other major European economies. This difference also contributes to the European REER reflecting an overvaluation or a competitiveness disadvantage.

Compared to its main trading partners, only Germany's ULC-based REER has depreciated, ... ULC- and CPI-Based Real Exchange Rate Index $(2000=100)$
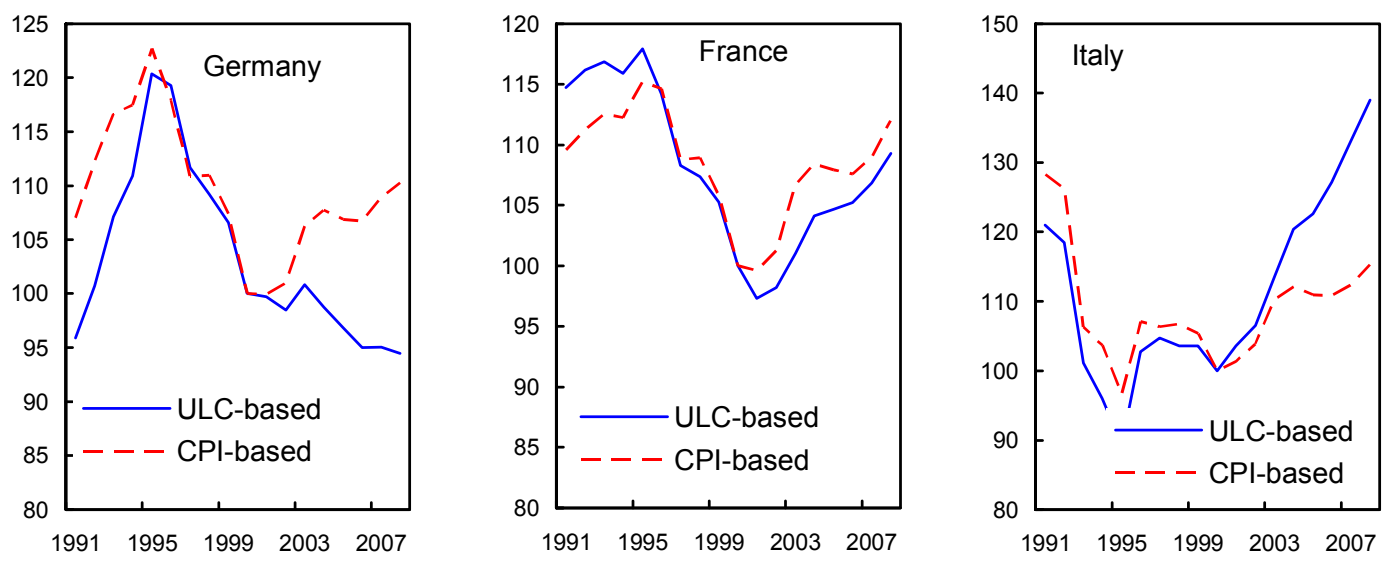

Source: IFS.

\section{While moderation in real wages has helped Germany, sustainability of this} advantage cannot be assumed.

Germany has recently enjoyed strong export growth. However, export shares have not necessarily increased, either in world trade or in the eurozone.

Thus, wage moderation has helped principally stem the decline in market shares. Germany has gained relative to other advanced economies, including those in the eurozone, but has continued to lose ground to lower wage economies despite the wage

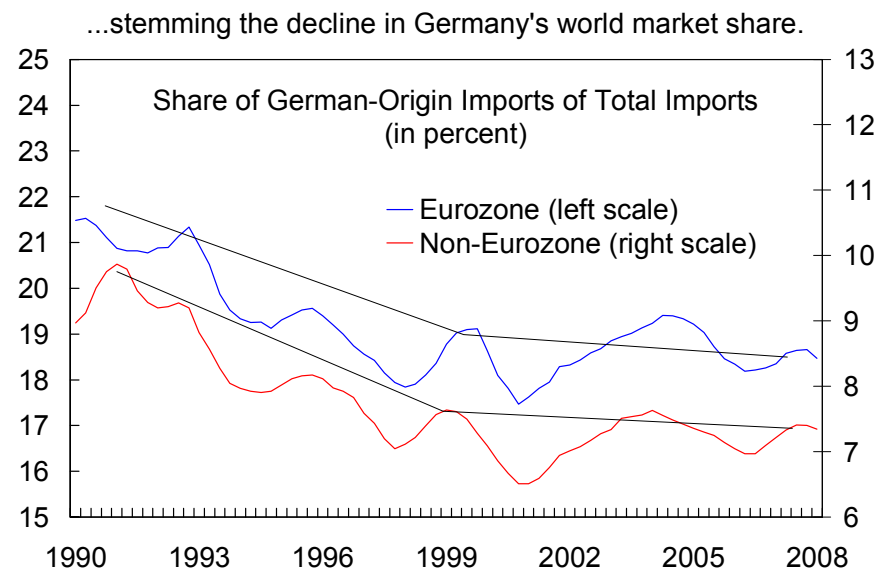
moderation and efforts to position its products in more differentiated markets. For now, this process may continue with the claims on a growth dividend remaining muted in the difficult economic environment. But wage claims are likely to resurface and productivity gains are not assured. 


\section{Balancing Tensions in Public Finances}

\section{Following impressive expenditure-based consolidation in prior years, the}

headline deficit is set to be balanced in 2008. The pressure on the deficit increased in 2008 on account of revenue losses (of about $1 / 2$ percent of GDP resulting from corporate income tax reform and the reduction in unemployment contributions) and the increase in civil service wages (onetenth percent of GDP). Compensating for these factors were cyclical gains in revenues and reduced social benefits with higher employment (Table 6). Though the earlier bank rescue measures raised the deficit, the recent financial sector stabilization package has not had an impact on the deficit

Fiscal consolidation has been expenditure-based.

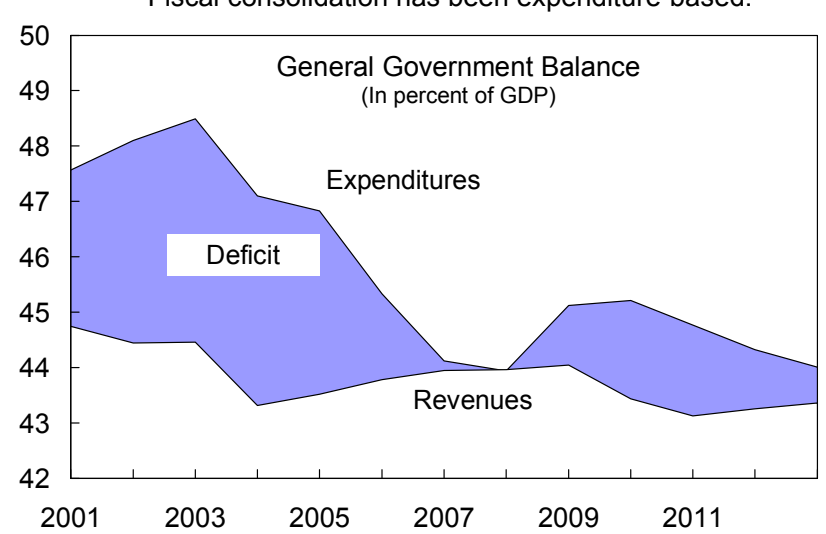
since the support leads to an acquisition of a financial asset; but it does imply higher public debt that finances the support.

36. For 2009, the headline deficit will rise with the cyclical downturn. Policy measures approved in fall 2008 to raise social benefits, change social security contributions, and provide investment incentives are expected to raise the deficit by about 0.2 percentage point of GDP in 2009. The bigger impact on the headline deficit will come from the worsening economic situation. As a result of cyclical pressures, the general government deficit is expected to be 1.1 percent of GDP. The authorities currently project the deficit at $1 / 2$ percent of GDP, but with the likely revision in their economic outlook assumptions, their projection will be close to that of staff.

\begin{tabular}{|c|c|c|c|c|c|c|c|}
\hline \multicolumn{8}{|c|}{$\begin{array}{c}\text { General Government Fiscal Position } \\
\text { (Percent of GDP) }\end{array}$} \\
\hline & & & & & & $\operatorname{Prc}$ & \\
\hline & 2003 & 2004 & 2005 & 2006 & 2007 & 2008 & 2009 \\
\hline Overall balance & -4.0 & -3.8 & -3.3 & -1.5 & -0.2 & 0.0 & -1.1 \\
\hline $\begin{array}{l}\text { Revenue } \\
\text { of which }\end{array}$ & 44.5 & 43.3 & 43.5 & 43.8 & 43.9 & 44.0 & 44.1 \\
\hline Direct taxes & 10.4 & 10.0 & 10.1 & 10.8 & 11.2 & 11.1 & 11.1 \\
\hline Indirect taxes & 11.8 & 11.8 & 11.8 & 12.1 & 12.6 & 12.5 & 12.5 \\
\hline Primary expenditure & 44.0 & 42.8 & 42.7 & 41.1 & 39.9 & 39.9 & 41.1 \\
\hline $\begin{array}{l}\text { Social benefits } \\
\text { of which }\end{array}$ & 27.5 & 26.8 & 26.6 & 25.8 & 24.6 & 24.8 & 25.7 \\
\hline Pensions & 12.5 & 12.3 & 12.2 & 11.8 & 11.4 & 11.2 & 11.6 \\
\hline Health & 7.7 & 7.4 & 7.5 & 7.4 & 7.4 & 7.5 & 7.7 \\
\hline Other expenditures & 16.5 & 16.1 & 16.0 & 15.4 & 15.2 & 15.1 & 15.4 \\
\hline Structural balance & -3.2 & -2.6 & -2.2 & -1.2 & -0.2 & -0.5 & -0.6 \\
\hline
\end{tabular}




\section{A. Fiscal Stimulus: Size and Composition}

\section{A moderate fiscal stimulus in $\mathbf{2 0 0 8}$ may be followed by a broadly neutral stance}

in 2009. The fiscal stimulus of 2008

largely results from the tax breaks

referred to above. In 2009, the

severe macroeconomic downturn

will precede the deterioration of the

tax base (buoyed, in part, by the

agreed wage increases under the

2008 wage negotiation rounds),

creating a structural fiscal

improvement. This will be offset by

the stimulus packages announced in

early October and early November

(Table 7). As such, the structural

A broadly neutral fiscal stance is expected for 2009 .

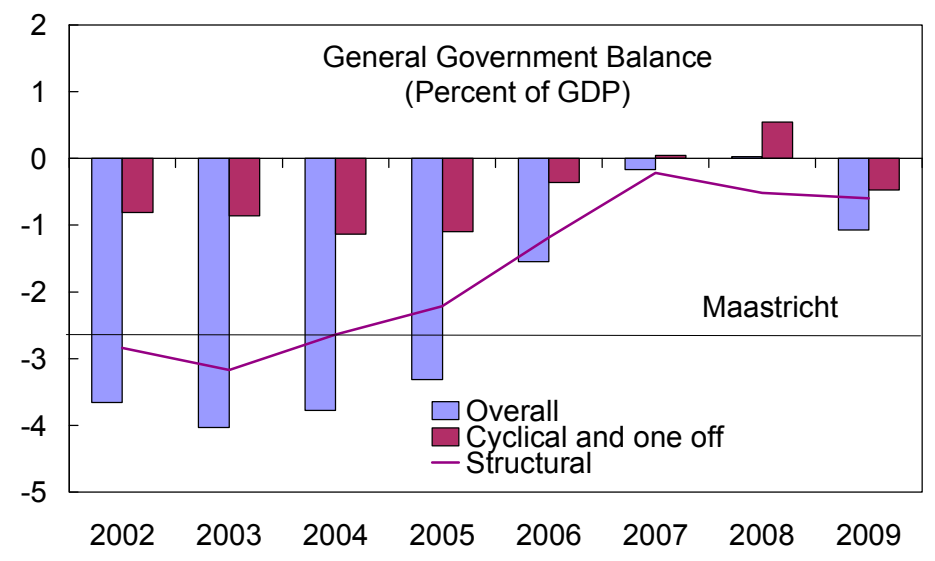

deficit will be broadly stable.

\section{Significant frontloaded and internationally-coordinated fiscal stimulus is}

necessary. Staff viewed the authorities' measures as relatively modest, especially in 2009 when they are most needed to boost demand. Staff proposed that, assuming multipliers of 0.4-0.5, bringing GDP growth to zero in 2009 would require a frontloaded fiscal stimulus of $1 \frac{1}{2}$ to 2 percent of GDP. The authorities were concerned that such an effort would open the door to demands from diverse lobbies, undermining hard-won consolidation,

Illustrative Fiscal Stimulus Package (in billions of euros, unless otherwise specified)

\begin{tabular}{lrrr}
\hline & 2008 & 2009 & 2010 \\
\hline One-off payments to low-income households & 3.6 & & \\
Accelerated health care reform & & 10.0 & 8.5 \\
Accelerated public investment & & 24.9 & 0.5 \\
Authorities' Fall 2008 fiscal measures & & 4.8 & 14.8 \\
& & & \\
Total & 3.6 & 39.7 & 23.8 \\
(in percent of GDP) & 0.1 & 1.6 & 0.9 \\
\hline
\end{tabular}
and may prove ineffective if multipliers are smaller. Staff acknowledged this risk, but argued that this concern needs to be weighed against the threat that with anxiety at unusually high levels - and even with the benefit of the FMSF - a self-reinforcing costly loss in output could ensue. The authorities and staff agreed that-given extensive evidence of trade, financial, and sentiment spillovers - the stimulus would be particularly effective if German actions were part of a joint European effort to bolster demand.

39. The international experience points to important lessons for making a stimulus effective. Drawing on these lessons, the practical implications for Germany were discussed (see text table below for possible measures and their likely effectiveness):

- $\quad$ Staff expressed concern that private investment incentives (through accelerated depreciation) and increased lending to small- and medium-sized firms through the 
development bank, KfW, were unlikely to raise investment while business confidence was low.

- $\quad$ The stimulus could be initiated by transfer payments to vulnerable households (to impart an immediate demand impulse). The focus on the poorer households would direct funds to where they would most likely be spent and also mollify those who have felt that the dividend from the recent upswing eluded them. The existing system of means-tested social benefits already identifies likely recipients.

- $\quad$ Bringing forward the proposed reduction in social security contributions - by increasing immediately the federal government contribution to the Health fundwould reduce high labor tax rates and, while boosting sluggish private consumption, also support potential growth.

- $\quad$ Accelerating maintenance investment and infrastructure projects already in the pipeline could significantly boost output and, therefore, confidence, but, as most infrastructure investment is undertaken at the local level, these may require federal top-up payments to municipalities.

- In contrast, a value-added tax rate reduction would be less appropriate. Staff agreed with the authorities that a VAT cut would be ineffective because it would raise policy uncertainty by reversing the 2007 hike and it would counteract the long-term goal of moving towards indirect taxation.

Though cautious about the efficacy of transfer payments, the authorities agreed that lowering the social security contributions, and accelerating public infrastructure projects are sensible measures, and could be part of a package, should one be needed at a later date. For the time being, they will monitor the economic situation, and the effectiveness of the already announced measures. 
Fiscal Stimulus Measures (in approximate order of effectiveness)

\begin{tabular}{|c|c|c|c|c|}
\hline Measure & $\begin{array}{l}\text { Cost- } \\
\text { Effectiven } \\
\text { ess }\end{array}$ & $\begin{array}{l}\text { Lag from } \\
\text { Enactment 1/ }\end{array}$ & $\begin{array}{l}\text { Uncertainty } \\
\text { about Effects }\end{array}$ & Comments \\
\hline \multicolumn{5}{|l|}{ Expenditures } \\
\hline $\begin{array}{l}\text { One-off transfer payments to low-income } \\
\text { households through social benefit system }\end{array}$ & Large & Short & Small & $\begin{array}{l}\text { Advantage: Exising social benefit system identifies low-income } \\
\text { households with the highest multipliers. } \\
\text { Disadvantage: Political pressures to continue one-off payments. }\end{array}$ \\
\hline $\begin{array}{l}\text { Targeted transfers to cash-strapped state and } \\
\text { local governments to avoid cut backs in key } \\
\text { services }\end{array}$ & Large & Short & Small & $\begin{array}{l}\text { Advantage: Given spending bias of states' fiscal policy, transfers } \\
\text { likely to be spent rapidly. } \\
\text { Disadvantage: Political pressures to continue one-off payments. }\end{array}$ \\
\hline $\begin{array}{l}\text { Targeted public investment program on projects } \\
\text { that can be rolled out and finished quickly }\end{array}$ & Large & Medium & Small & $\begin{array}{l}\text { Disadvantage: Tends to take } 2-3 \text { quarters to develop and enact. } \\
\text { The disadvantage could be mitigated by implementing } \\
\text { infrastructure maintenance projects and accelerating projects } \\
\text { that are in advanced stages of the pre-implementation process. }\end{array}$ \\
\hline Incentives for new investment & Small & Medium & Large & $\begin{array}{l}\text { Disadvantage: Stimulus may be delayed because of lags in } \\
\text { developing new investment programs and may be ineffective } \\
\text { given current business confidence. May be difficult to repeal in } \\
\text { the upswing. }\end{array}$ \\
\hline \multicolumn{5}{|r|}{$e_{1}$} \\
\hline $\begin{array}{l}\text { Reduce social security contributions by raising } \\
\text { federal transfer to Health Fund to full amount } \\
\text { planned for } 2016\end{array}$ & Large & Small & Small & $\begin{array}{l}\text { Advantage: Implementation already planned for } 2016 \text {. Raises } \\
\text { take-home wage of poorer households, which could not be } \\
\text { reached with a personal income tax rate cut because of incomes } \\
\text { below the threshold for income tax payments. } \\
\text { Disadvantage: Benefit increases with income. }\end{array}$ \\
\hline $\begin{array}{l}\text { Withholding holiday for employee social security } \\
\text { contributions }\end{array}$ & Medium & Medium & Large & $\begin{array}{l}\text { Advantage: Increase in take-home pay tends to be more } \\
\text { effective than income tax rebate. } \\
\text { Disadvantage: Households may save increase in take-home pay } \\
\text { in anticipation of end-of-year payment. }\end{array}$ \\
\hline Income tax rebate & Large & Medium & Large & $\begin{array}{l}\text { Disadvantage: Rebate that increases in proportion to tax liability } \\
\text { and, hence, income is less effective than uniform rebate } \\
\text { because it is less well-targeted. Processing time may cause } \\
\text { delays. }\end{array}$ \\
\hline $\begin{array}{l}\text { Extending operating loss and carry-back } \\
\text { provisions }\end{array}$ & Small & Medium & Large & $\begin{array}{l}\text { Advantage: Provisions can ease cash constraints and enhance } \\
\text { effectiveness of investment incentives. } \\
\text { Disadvantage: Provisions have little effect in themselves. }\end{array}$ \\
\hline
\end{tabular}

Source: Congressional Budget Office, Fund staff assessments, World Economic Outlook.

1/ Approximate time between enactment and when the policy would have achieved the bulk of its effect on aggregate demand.

Short means less than 1/2 a year. "Medium" means 1/2-1 year. "Long" means more than 1 year.

\section{B. Ensuring Long-Term Fiscal Sustainability}

40. Sustainability of public finances requires a recommitment to a fiscal rule. The authorities aim to amend the Basic Law to establish a rule that limits the structural budget balance to close to zero from 2011. The importance of such a rule is even greater now that the stimulus will add to the challenge of ensuring long-term fiscal sustainability. The proposed fiscal rule - which staff stressed should be applied also to the states - would provide the mechanism to regain lost ground with ambitious initiatives to achieve fiscal sustainability as the economy embarks on its recovery path. The authorities welcomed staff's emphasis on this principle. Reintroduction of a wealth tax, greater flexibility in the retirement age, and cost efficiencies, especially in health care and fiscal decentralization, will need to be actively considered. 


\section{Despite the Agenda 2010 labor market and social security reforms, public}

finances remain vulnerable. The authorities estimate that, under a benign scenario, public sector debt could stabilize at about 10 percent of GDP. Staff projectionsincluding the recent pension increases above the established formulacaution, however, that public sector debt could reach 50 percent of GDP. If additional downside fiscal risks materialize without prompt offsetting measures, public sector debt could quickly rise manifold. Of particular importance are the risks associated with healthcare costs due to an aging population.

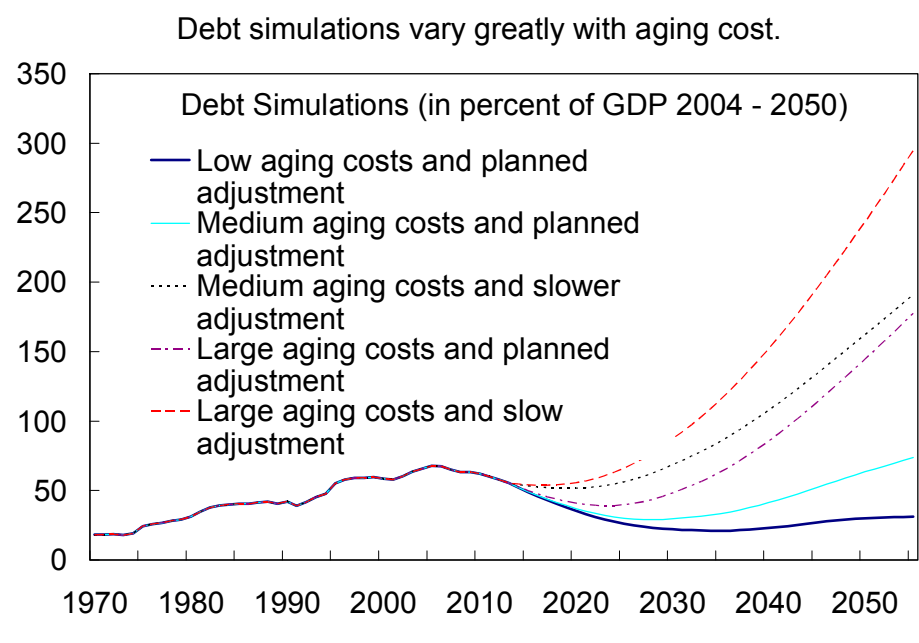

\section{Further cost savings measures could be generated beyond the $\mathbf{2 0 0 7}$ healthcare}

reform. In particular, further rationalization could be achieved in pharmaceutical expenditures. Also, incentives for efficiency-enhancing competition could be strengthened. From 2009, a Health Fund, financed by the federal budget and individual contributions, will allocate funds to insurers of the public health insurance system. In addition, the insured will be required to pay fees directly to the insurers, of on average, five percent of the total estimated costs for the year. While this set up provides some incentives to insurers to reduce costs - because lower fees charged to the insured will attract more clients - it also creates incentives to attract the healthier and wealthier. The OECD has suggested that alternative fee structures may create stronger cost saving incentives. The authorities recognize that easing the pressure of healthcare costs will continue to require new efforts.

43. States need to contribute to fiscal consolidation. To date, states have added to the accumulation of public debt. The cooperative system of uniform spending standards and equalizing fiscal transfers, characterized by a high degree of revenue sharing by international comparison, has muted incentives for fiscal discipline. In particular, states receiving net transfers have engaged in pro-cyclical expenditure and delayed debt consolidation (Box 4). Several reforms should be considered: (a) structural-deficit or expenditure-based fiscal rules at the federal and state levels to strengthen fiscal discipline and reduce pro-cyclicality; (b) a surveillance mechanism, based on consistent reporting standards; (c) increased state-level tax autonomy to increase incentives for revenue collection and reduce dependence on supplementary federal grants. The authorities welcomed the staff's support for a fiscal rule which would help long-term fiscal sustainability. They agreed also that a broader federalism reform would be desirable but did not see much scope for progress during this legislative period. 

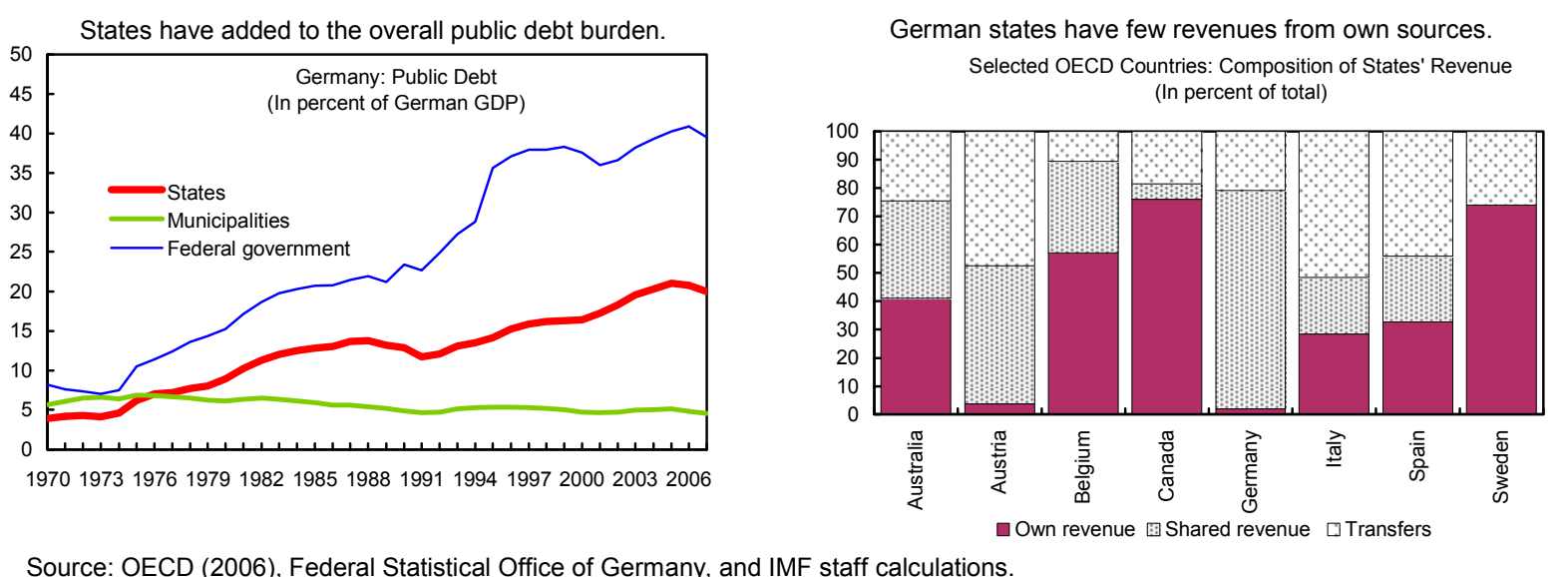

Source: OECD (2006), Federal Statistical Office of Germany, and IMF staff calculations.

\section{Box 4. Fiscal Discipline in Germany: A Federal Matter?}

Germany's arrangement for financing subnational spending stands out in two ways. First, subnational taxing autonomy is severely limited with own-source revenue accounting for less than 2 percent of total state revenue. Second, an extensive system of transfers ensures an almost complete (and constitutionally mandated) equalization of resources across states. After initial stages of allocating joint taxes and redistributing VAT, revenues are further equalized through horizontal transfers (totaling 0.3 percent of GDP in 2007), to which supplementary federal grants (totaling 0.6 percent of GDP in 2007) are added in a final stage.

Two main implications derive. First, strong reliance on transfers encourages states to spend without due consideration for debt sustainability (the so-called 'soft budget constraint'). In addition, dependence on transfers to finance spending can result in pro-cyclical spending, especially in good times.

\section{Staff analysis confirms that reliance on transfers} weakens fiscal discipline. A fiscal reaction function for a panel of the "old" states is estimated, relating changes in primary expenditure to a computed output gap and the lagged deficit. As illustrated by the results in the table, net recipient states have not reduced expenditures significantly in response to rising deficits. Moreover, these states have pursued pro-cyclical policies, particularly by raising expenditures in good times. Net contributing states, in contrast, have ensured fiscal sustainability through expenditure adjustment and been less pro-cyclical.

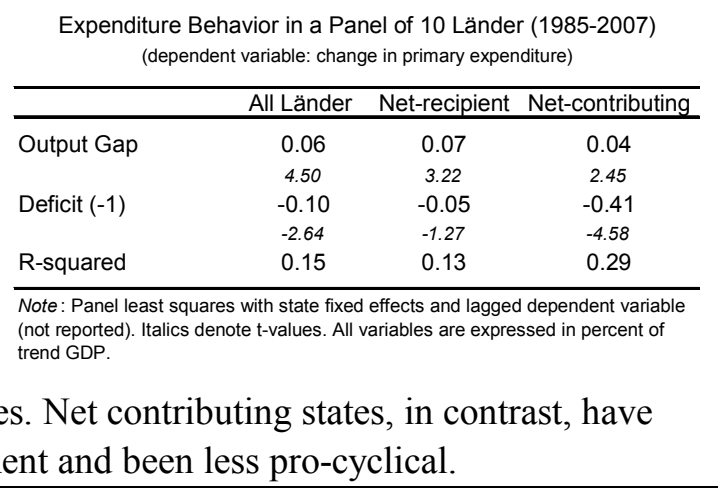




\section{Staff Appraisal}

44. Germany faces the prospect of a sizeable, and possibly extended, economic downturn. Following GDP contraction in the second and third quarters of 2008, a further four quarters of negative GDP growth and sluggish recovery thereafter appear likely. In 2009, GDP is projected to fall by 0.8 percent and the 0.5 percent growth in 2010 would be well below the potential of about $1 \frac{1 / 2}{2}$ percent. The risk is that corporate and financial sector stresses, thus far dissociated from each other in Germany, may become more intertwined. The longer the global shocks persist, the more severe and prolonged would be the weakness.

45. Given strong spillovers, policy measures to contain the risk of a self-reinforcing and costly slump will achieve more if coordinated internationally. Global impulses, felt forcefully in Germany, are rapidly transmitted to other economies. A German economic slowdown lowers growth in the rest of Europe, which feeds back to Germany, despite its small competitiveness advantage. Moreover, a necessary reduction of German banks' exposure to emerging markets would generate cascading spillovers. Thus, giving due consideration to its domestic objectives, Germany stands to benefit from an internationally coordinated approach to managing global risks.

- In this regard, continued actions to strengthen the financial safety net will buttress the recent initiatives. Germany's request for an FSAP update is timely.

- $\quad$ A similar risk-management philosophy should apply to fiscal policy.

46. The Financial Market Stabilization Fund (FMSF), which has been vital to shielding the financial sector, could be a stepping stone for broader financial reforms. The German approach has differed from that in other countries: it is voluntary and banks may choose from a range of stabilization measures. Given the low absolute level of capital in several banks, a more proactive recapitalization is desirable, particularly in view of expected asset quality deterioration. Moreover, SoFFin, the agency administering the FMSF, could use its authority more broadly for enhancing the soundness of the financial sector.

- $\quad$ The proactive restructuring and downsizing of the Landesbanken requires early attention. SoFFin could fruitfully work with the Landesbanken in achieving this goal.

- $\quad$ The authorities should possess the ability to act expeditiously under a special bank resolution regime. A move in that direction has been made for bank recapitalizations under SoFFin allowing dilution of shareholder rights. In this line, further modifications of the legal framework for orderly bank resolutions are warranted.

47. A critical element of the financial safety net, deposit protection should be strengthened. The multiple protection schemes have typically relied on ex post burdensharing, which elevates risks in periods of stress. A base layer of mandatory deposit 
insurance - ex ante funded by contributions from all banks - would provide unified terms of protection for depositors and reduce incentives to shift deposits among the existing schemes. Evolving European Union rules should provide guidance on policies related to deposit insurance.

48. The case for a tighter bank regulatory and supervisory process has become more compelling. To respond promptly to problem situations, supervisors have a heightened need for information on the current status of bank soundness. This implies, first, significantly reduced reliance on external auditors. Additionally, prudential regulation and supervision should be linked to a system of macro-surveillance and stability analysis. As such, greater consolidation of regulatory and supervisory resources could yield significant benefits.

49. Additional significant fiscal stimulus that is frontloaded, well targeted, and internationally coordinated is necessary. Following sustained fiscal prudence, the authorities have rightly taken steps to stimulate the economy. But their net size, timing, and focus on bolstering private investment imply that the immediate benefit will be limited.

- $\quad$ Bringing GDP growth to zero in 2009 would require a fiscal stimulus of $1 \frac{1}{2}$ to 2 percent of GDP. Such an effort would be particularly effective if German actions were part of a joint European effort to bolster demand.

- The German stimulus would likely be most effective if initiated by transfer payments to vulnerable households (to impart an immediate demand impulse), followed by bringing forward the proposed reduction in social security contributions (to lower labor taxation) and accelerating infrastructure projects (possibly through top-up federal payments to local communities). In contrast, a value-added tax rate reduction would be less appropriate.

50. These actions must be accompanied by a credible long-term commitment to fiscal sustainability. This remains a concern, especially with regard to trends in healthcare costs and the debt accumulation by the states.

- $\quad$ Containing healthcare costs requires further rationalization of pharmaceutical expenditures and strengthened efficiency-enhancing competition.

- More states taxation autonomy and a redesign of supplementary federal grants are required to improve states incentives for fiscal discipline.

- $\quad$ The proposed fiscal rule, limiting the structural budget balance to close to zero, should be applied also to the states, and would help regain lost ground and ensure fiscal sustainability.

51. It is proposed that the next Article IV consultation be held on the standard 12-month cycle. 
Figure 1. Germany: Credit Market Developments

Credit growth may be beginning to slow.

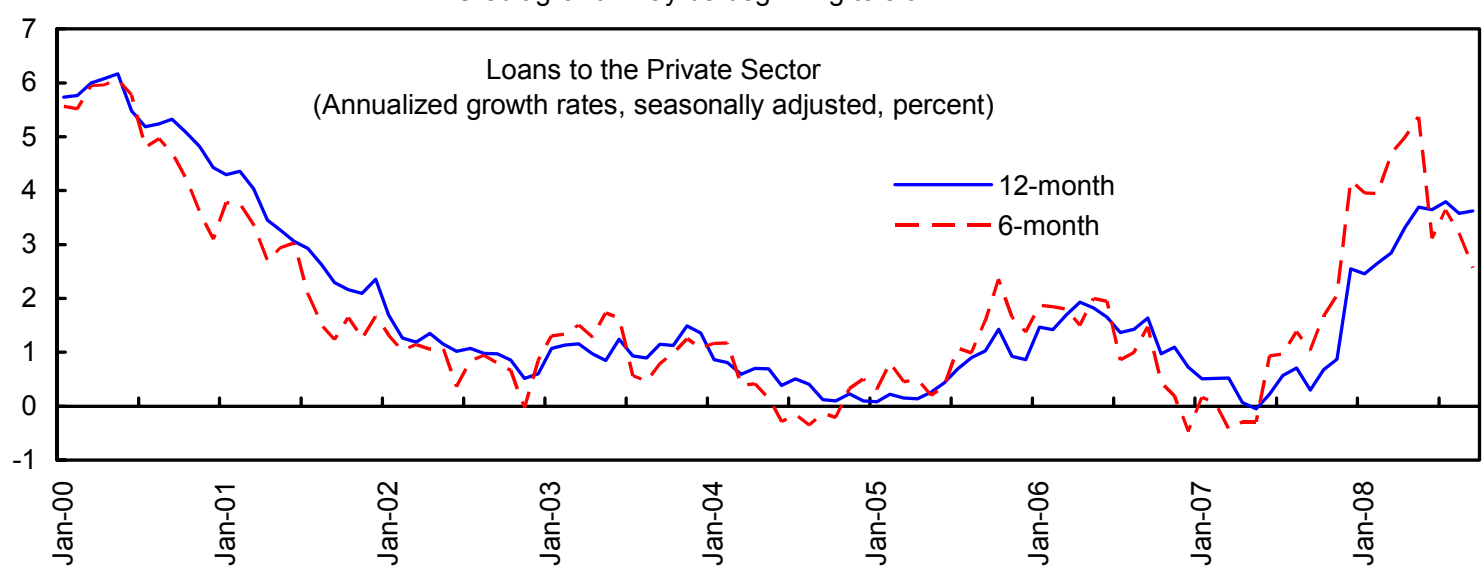

Despite the decline, credit growth to nonfinancial enterprises was relatively robust.

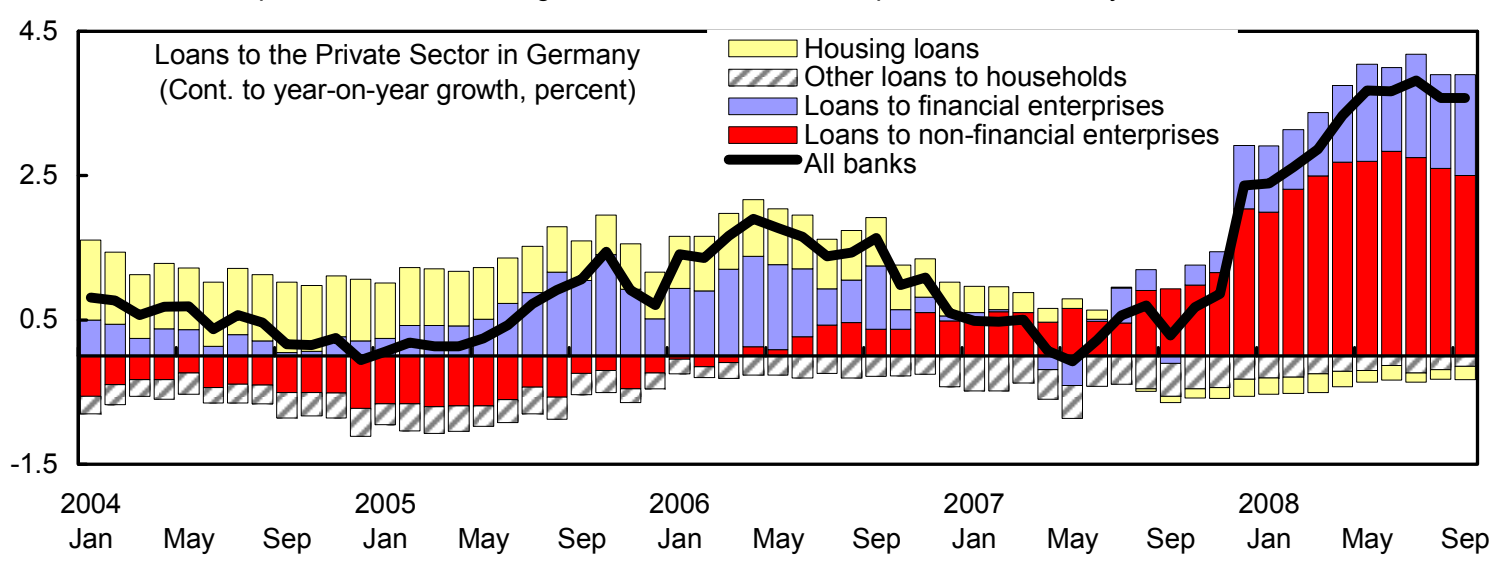

All types of lending institutions have contributed to credit growth.

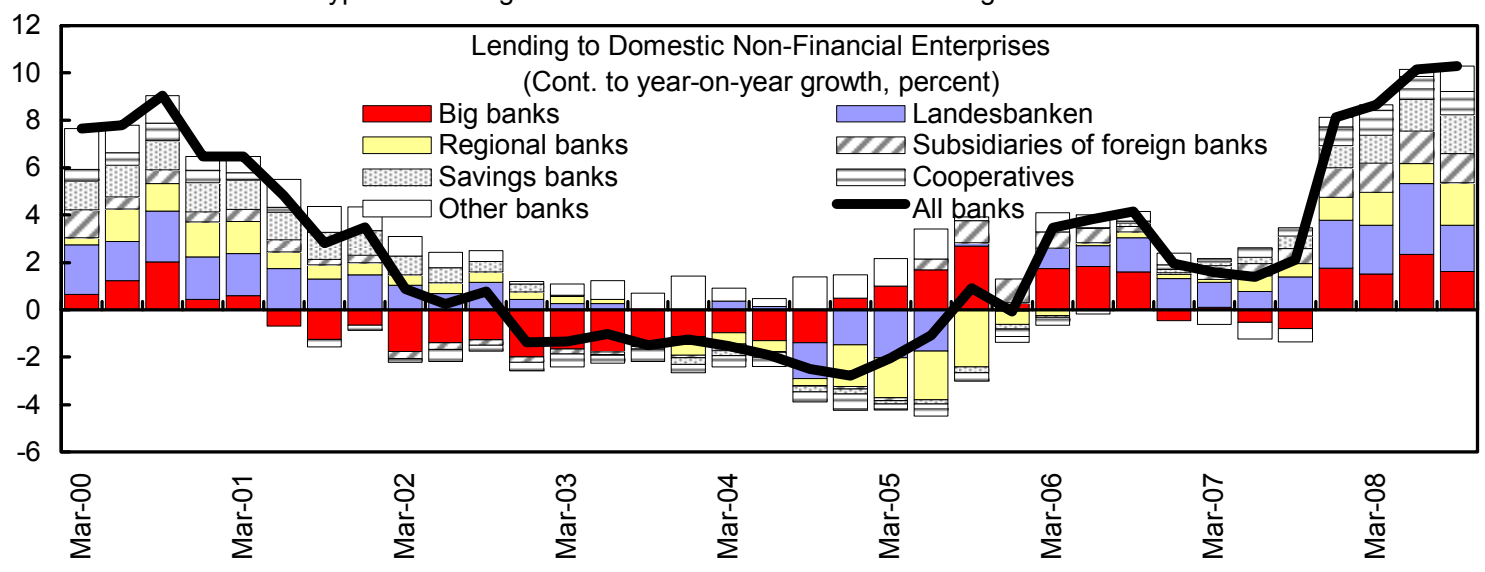

Source: Bundesbank, and IMF staff calculations. 
Figure 2. Germany: Probabilities of Default by Sector (in percent)
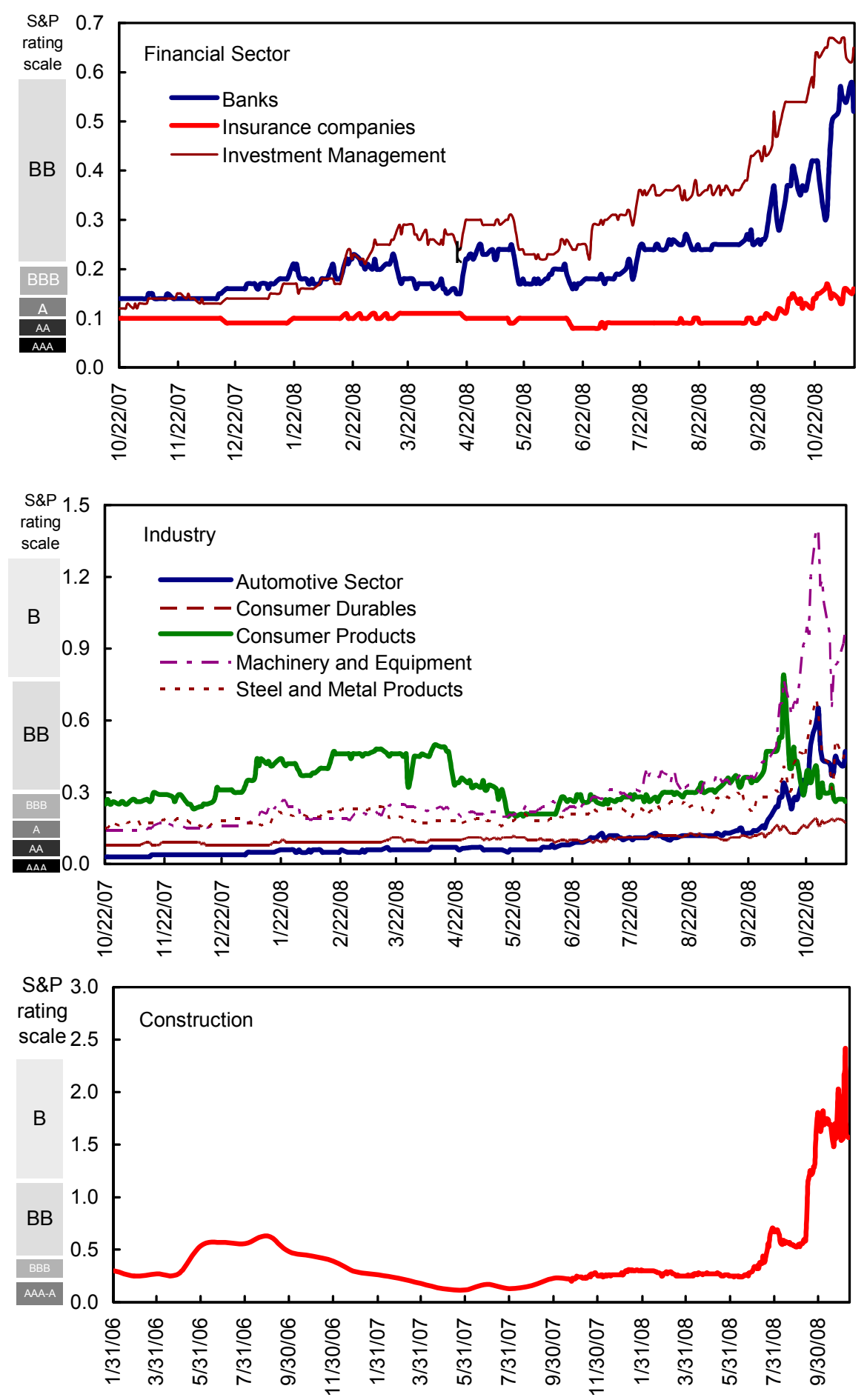

Source: Bloomberg, Fund staff estimates. 
Figure 3. Germany: Balance Sheets of Nonfinancial Corporates

Corporates enter this recession with lower net worth, ...

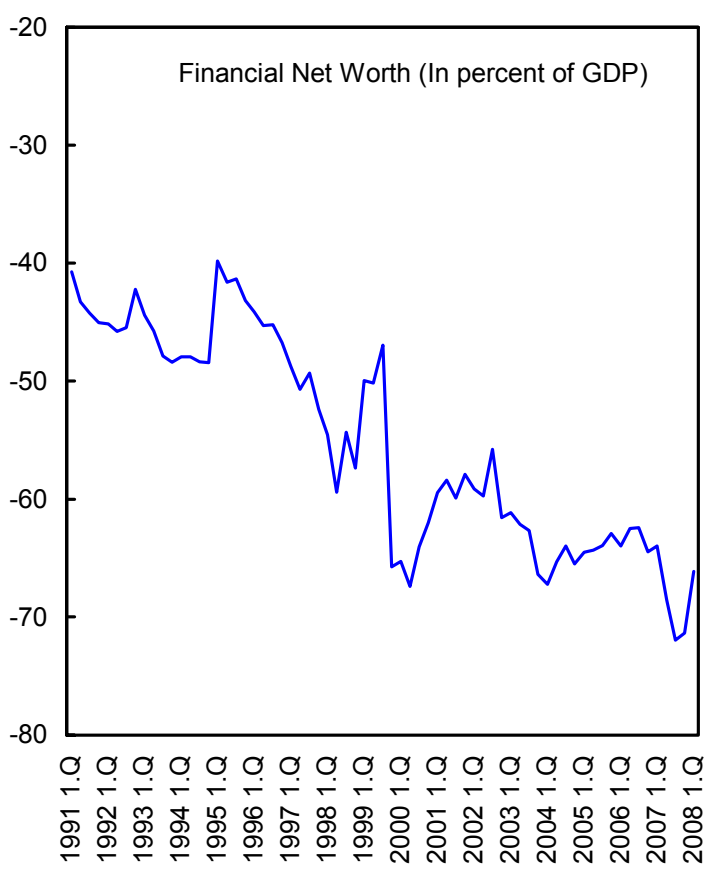

... a better capital position, ...

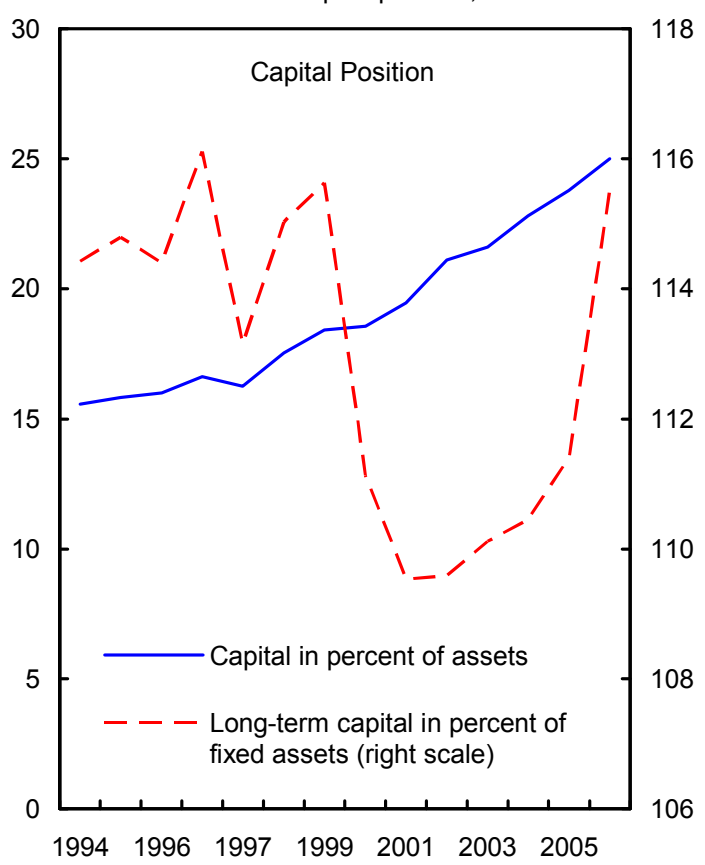

... but fewer short-term liabilities, ...
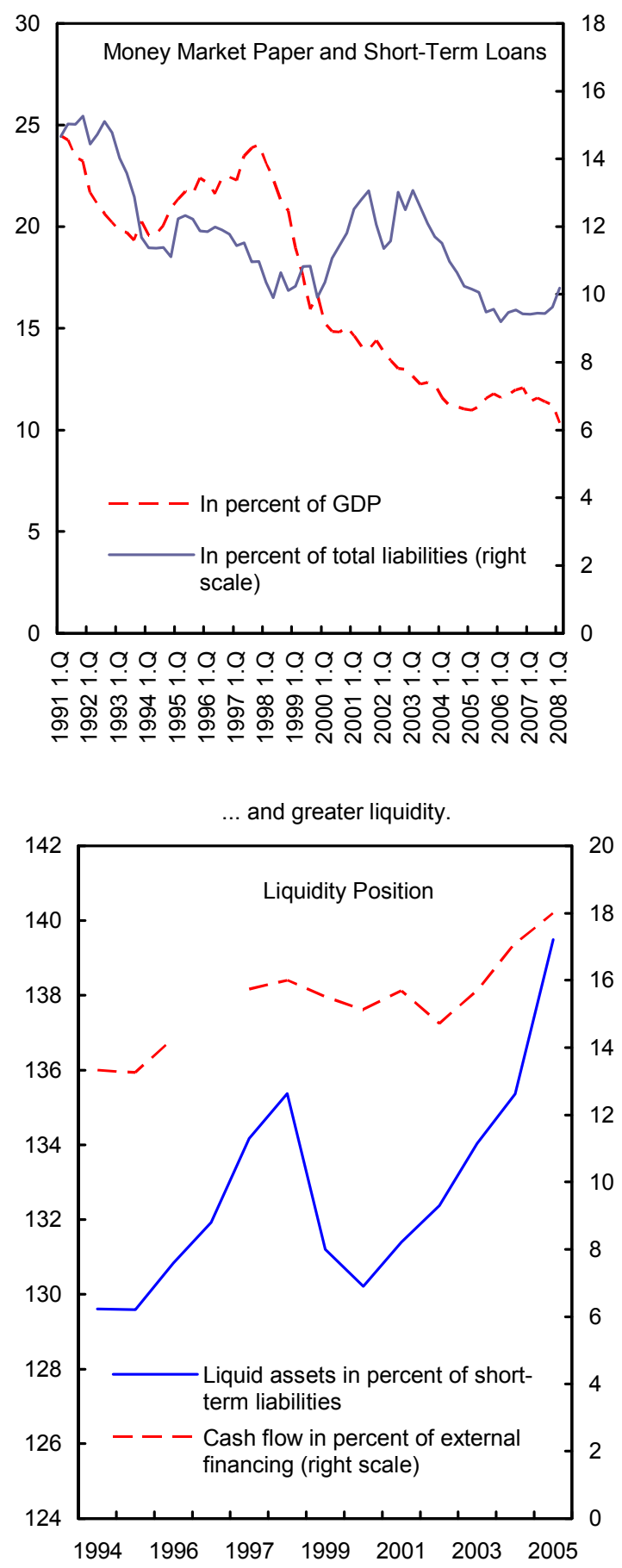

Source: Bundesbank. 
Figure 4. Central and Eastern Europe: Spillovers from Germany Eastern Europe's dependence on exports to Germany has risen and is especially large in the Czech and Slovak Republics and Hungary.
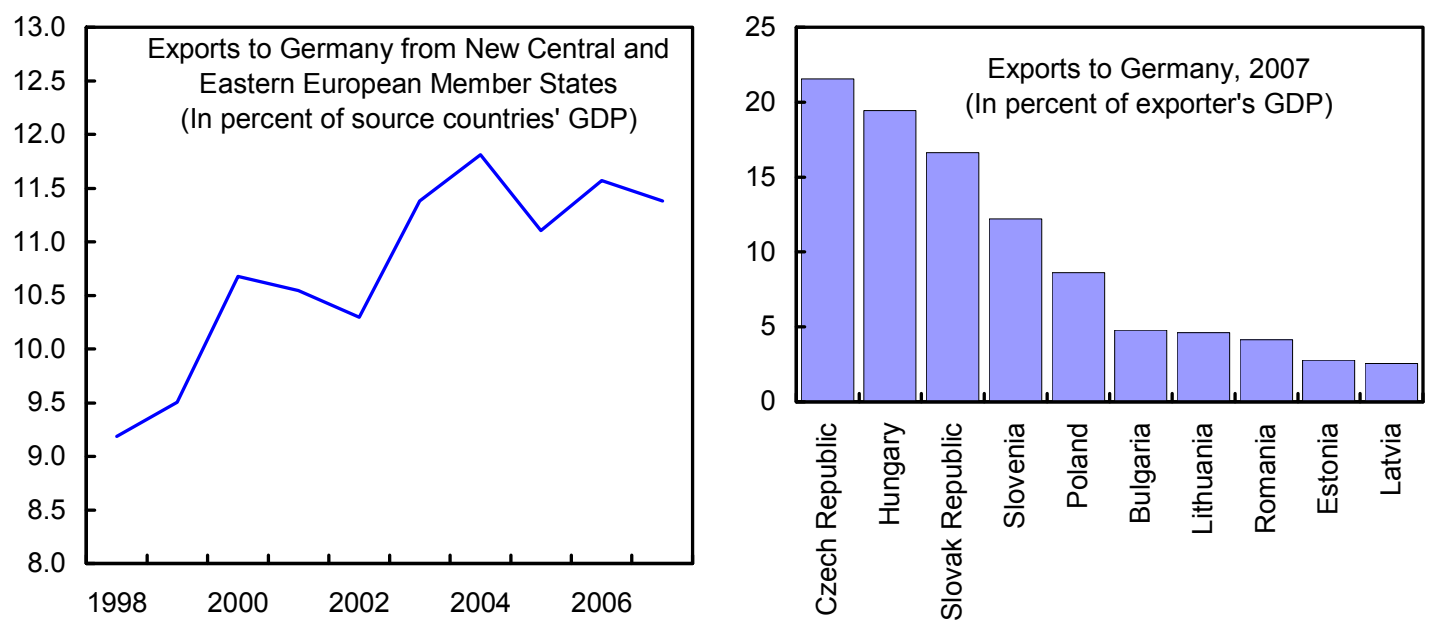

The Czech and Slovak Republics and Hungary rely particularly heavily on German FDI.
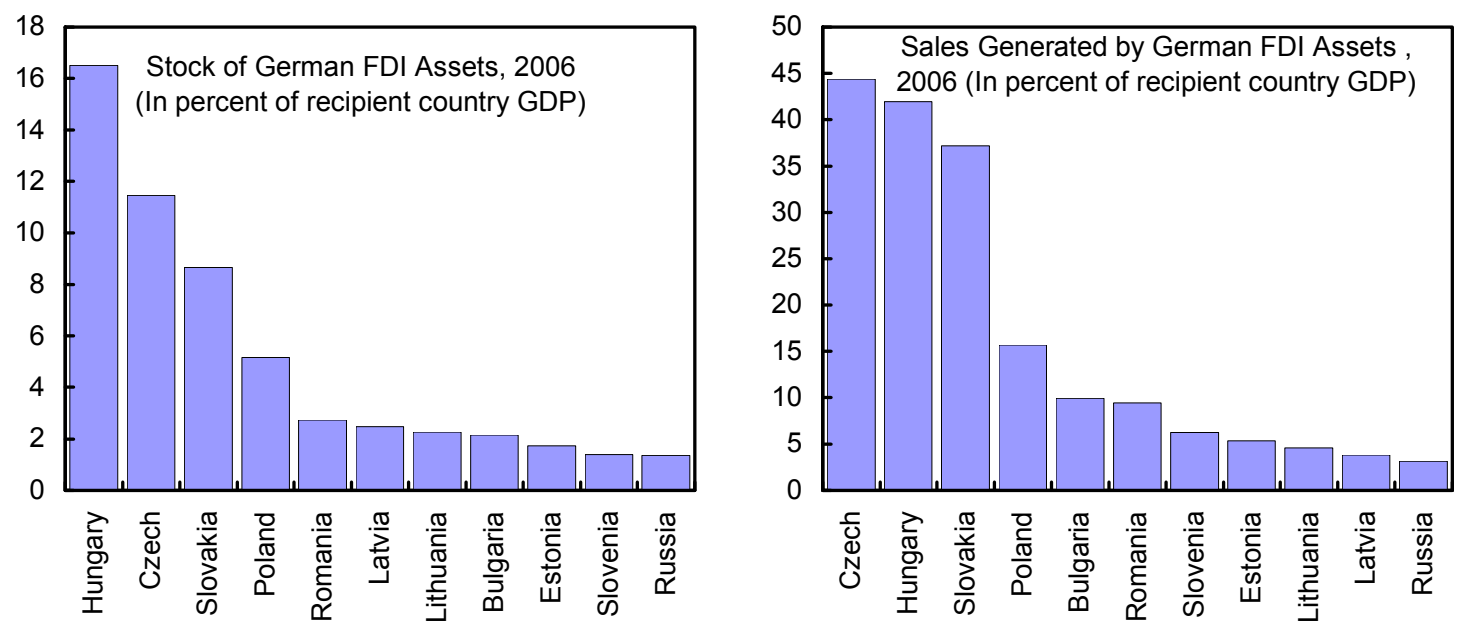

While German banks' exposure to Eastern European banks is limited, the Hungarian, Latvian, and Polish banking systems are exposed to German banks.
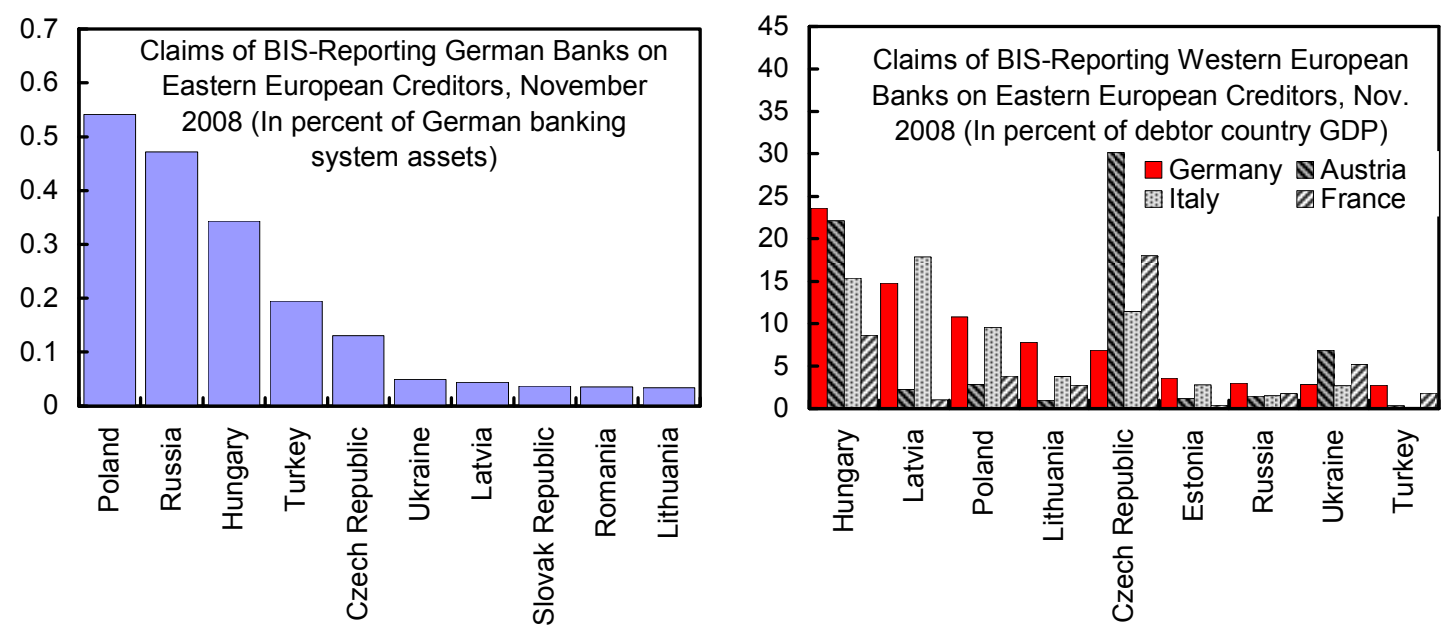

Source: Bundesbank, BIS, Direction of Trade Statistics. 
Table 1. Germany: Selected Economic Indicators

Total area Total population (2007) GDP per capita (2007)
357,041 square kilometers

82.2 million

US $\$ 40,400$

\begin{tabular}{|c|c|c|c|c|c|c|c|c|c|}
\hline & 2002 & 2003 & 2004 & 2005 & 2006 & 2007 & $20081 /$ & $20091 /$ & $20101 /$ \\
\hline & \multicolumn{9}{|c|}{ (Percentage change) } \\
\hline \multicolumn{10}{|l|}{ Demand and supply } \\
\hline Private consumption & -0.8 & 0.1 & 0.1 & 0.2 & 1.0 & -0.4 & -0.2 & -0.3 & 0.1 \\
\hline Public consumption & 1.5 & 0.4 & -0.7 & 0.4 & 0.6 & 2.2 & 2.7 & 2.5 & 2.0 \\
\hline Gross fixed investment & -6.1 & -0.3 & -0.3 & 1.1 & 7.7 & 4.3 & 5.4 & -2.7 & -0.5 \\
\hline Construction & -5.8 & -1.6 & -3.9 & -3.0 & 5.0 & 1.8 & 3.3 & -1.3 & 0.0 \\
\hline Machinery and equipment & -7.5 & 1.1 & 4.5 & 6.0 & 11.1 & 6.9 & 5.9 & -5.0 & -0.9 \\
\hline Final domestic demand & -1.4 & 0.1 & -0.1 & 0.4 & 2.3 & 1.1 & 1.6 & -0.3 & 0.4 \\
\hline Inventory accumulation 2/ & -0.6 & 0.5 & 0.0 & -0.4 & 0.0 & 0.1 & -0.3 & 0.6 & 0.0 \\
\hline Total domestic demand & -2.0 & 0.6 & -0.1 & 0.0 & 2.1 & 1.1 & 1.5 & 0.4 & 0.4 \\
\hline \multicolumn{10}{|l|}{ Exports of goods and } \\
\hline nonfactor services & 4.3 & 2.5 & 10.2 & 7.7 & 12.7 & 7.5 & 4.6 & -1.5 & 3.7 \\
\hline \multicolumn{10}{|l|}{ Imports of goods and } \\
\hline nonfactor services & -1.4 & 5.4 & 7.3 & 6.5 & 11.9 & 5.0 & 4.8 & 1.0 & 4.0 \\
\hline Foreign balance $2 /$ & 2.0 & -0.8 & 1.4 & 0.7 & 1.0 & 1.4 & 0.3 & -1.2 & 0.1 \\
\hline GDP & 0.0 & -0.2 & 1.2 & 0.8 & 3.0 & 2.5 & 1.7 & -0.8 & 0.5 \\
\hline \multirow[t]{2}{*}{ Output gap (In percent of potential GDP) } & -0.2 & -1.7 & -1.9 & -2.3 & -0.8 & 0.4 & 0.9 & -1.0 & 0.0 \\
\hline & \multicolumn{9}{|c|}{ (In millions of persons, unless otherwise indicated) } \\
\hline \multicolumn{10}{|l|}{ Employment and unemployment } \\
\hline Labor force & 42.5 & 42.6 & 43.0 & 43.3 & 43.2 & 43.3 & 43.4 & 43.5 & 43.5 \\
\hline Employment & 39.0 & 38.6 & 38.8 & 38.8 & 39.0 & 39.7 & 40.2 & 39.9 & 39.8 \\
\hline Unemployment $3 /$ & 3.5 & 3.9 & 4.2 & 4.6 & 4.2 & 3.6 & 3.2 & 3.6 & 3.7 \\
\hline Unemployment rate (in percent) 4 / & 7.7 & 8.8 & 9.2 & 10.6 & 9.8 & 8.4 & 7.3 & 8.3 & 8.5 \\
\hline & \multicolumn{9}{|c|}{ (Percentage change) } \\
\hline \multicolumn{10}{|l|}{ Prices and incomes } \\
\hline GDP deflator & 1.4 & 1.2 & 1.0 & 0.7 & 0.5 & 1.8 & 1.3 & 1.1 & 1.0 \\
\hline Consumer price index (harmonized) & 1.4 & 1.0 & 1.8 & 1.9 & 1.8 & 2.3 & 2.8 & 1.0 & 0.8 \\
\hline Average hourly earnings (total economy) & 2.0 & 1.7 & 0.4 & 1.0 & 1.1 & 1.4 & 1.0 & 0.7 & 0.2 \\
\hline Unit labor cost (industry) & 1.5 & -1.3 & -3.1 & -4.2 & -4.0 & -3.1 & -0.6 & -0.8 & -1.3 \\
\hline Real disposable income 5/ & -0.2 & 0.5 & 0.2 & 0.3 & 0.9 & 0.0 & 0.5 & -0.1 & 0.1 \\
\hline Personal saving ratio (in percent) & 9.9 & 10.3 & 10.4 & 10.6 & 10.5 & 10.8 & 11.4 & 11.6 & 11.5 \\
\hline
\end{tabular}

Sources: Deutsche Bundesbank; Federal Statistical Office; IMF, World Economic Outlook; IMF, International Financial Statistics; and staff estimates and projections.

1/ IMF staff projections.

2/ Growth contribution.

3/ National accounts definition

4/ Eurostat definition.

5/ Deflated by the national accounts deflator for private consumption. 
Table 1. Germany: Selected Economic Indicators (concluded)

\begin{tabular}{|c|c|c|c|c|c|c|c|c|c|}
\hline & 2002 & 2003 & 2004 & 2005 & 2006 & 2007 & $20081 /$ & $20091 /$ & $20101 /$ \\
\hline & \multicolumn{9}{|c|}{ (In billions of Euros, unless otherwise indicated) } \\
\hline \multicolumn{10}{|l|}{ Public finances $6 / 7 /$} \\
\hline \multicolumn{10}{|l|}{ General government } \\
\hline Expenditure & 1,031 & 1,049 & 1,041 & 1,050 & 1,052 & 1,069 & 1,097 & 1,129 & 1,152 \\
\hline (In percent of GDP) & 48.1 & 48.5 & 47.1 & 46.8 & 45.3 & 44.1 & 44.0 & 45.2 & 45.4 \\
\hline Revenue & 953 & 962 & 958 & 976 & 1,016 & 1,065 & 1,098 & 1,102 & 1,108 \\
\hline (In percent of GDP) & 44.4 & 44.5 & 43.3 & 43.5 & 43.8 & 43.9 & 44.0 & 44.1 & 43.7 \\
\hline Overall balance & -78 & -87 & -84 & -74 & -36 & -4 & 1 & -27 & -45 \\
\hline (In percent of GDP) & -3.7 & -4.0 & -3.8 & -3.3 & -1.5 & -0.2 & 0.0 & -1.1 & -1.8 \\
\hline Structural balance & -62 & -70 & -57 & -52 & -28 & -5 & -11 & -16 & -24 \\
\hline (In percent of potential GDP) & -2.9 & -3.2 & -2.6 & -2.3 & -1.2 & -0.2 & -0.5 & -0.6 & -1.0 \\
\hline \multicolumn{10}{|l|}{ Federal government } \\
\hline Overall balance & -36 & -40 & -51 & -57 & -30 & -19 & -15 & -30 & -41 \\
\hline (In percent of GDP) & -1.7 & -1.8 & -2.3 & -2.6 & -1.3 & -0.8 & -0.6 & -1.2 & -1.6 \\
\hline General government debt & 1,278 & 1,358 & 1,430 & 1,489 & 1,533 & 1,575 & 1,706 & 1,802 & 1,847 \\
\hline (In percent of GDP) & 59.6 & 62.8 & 64.7 & 66.4 & 66.0 & 65.0 & 68.4 & 72.1 & 72.8 \\
\hline \multicolumn{10}{|l|}{ Balance of payments } \\
\hline Trade balance 8/ & 124.2 & 118.8 & 139.6 & 144.4 & 146.3 & 189.2 & 204.6 & 195.5 & 187.5 \\
\hline Services balance & -35.7 & -34.5 & -29.3 & -24.9 & -15.6 & -16.3 & -15.8 & -20.8 & -23.6 \\
\hline Factor income balance & -18.0 & -15.1 & 20.4 & 25.7 & 37.6 & 42.0 & 26.6 & 13.0 & 10.6 \\
\hline Net private transfers & -15.7 & -15.2 & -16.7 & -17.6 & -14.4 & -16.1 & -19.5 & -19.5 & -19.8 \\
\hline Net official transfers & -11.8 & -10.0 & -11.2 & -11.0 & -12.5 & -14.5 & -13.0 & -13.0 & -13.2 \\
\hline Current account & 43.0 & 44.0 & 102.9 & 116.6 & 141.5 & 184.2 & 182.9 & 155.1 & 141.4 \\
\hline (In percent of GDP) & 2.0 & 2.0 & 4.7 & 5.2 & 6.1 & 7.6 & 7.3 & 6.2 & 5.6 \\
\hline Foreign exchange reserves (e. o. p.) 9/ & 40.5 & 32.5 & 29.3 & 33.7 & 28.6 & 27.7 & 32.0 & $\ldots$ & $\ldots$ \\
\hline Monetary data & \multicolumn{9}{|c|}{ (Percentage change) } \\
\hline Money and quasi-money (M3) 10/ 11/ & & 3.5 & 2.2 & 5.2 & 4.9 & 10.6 & 10.1 & $\ldots$ & $\ldots$ \\
\hline \multirow[t]{2}{*}{ Credit to private sector $10 /$} & 0.9 & 0.0 & -0.2 & 2.2 & 3.5 & 3.2 & 6.3 & $\ldots$ & $\ldots$ \\
\hline & \multicolumn{9}{|c|}{ (Period average in percent) } \\
\hline \multicolumn{10}{|l|}{ Interest rates } \\
\hline Three-month interbank rate $12 /$ & 3.3 & 2.3 & 2.1 & 2.1 & 3.7 & 4.8 & 5.1 & $\ldots$ & $\ldots$ \\
\hline Yield on ten-year government bonds 12 / & 4.8 & 4.1 & 4.1 & 3.6 & 3.8 & 4.3 & 4.0 & $\ldots$ & $\ldots$ \\
\hline \multicolumn{10}{|l|}{ Exchange rates } \\
\hline Euro per US\$ (annual average) 12/ & 1.06 & 0.88 & 0.80 & 0.80 & 0.80 & 0.73 & 0.75 & $\ldots$ & $\ldots$ \\
\hline Nominal effective rate $(1990=100) 13 /$ & 104.7 & 112.6 & 115.7 & 114.7 & 114.9 & 119.7 & 117.5 & $\ldots$ & $\ldots$ \\
\hline Real effective rate $(1990=100) 14 /$ & 101.4 & 105.9 & 105.5 & 102.2 & 99.1 & 97.9 & 94.0 & $\ldots$ & $\ldots$ \\
\hline
\end{tabular}

6/ Data for federal government are on an administrative basis. Data for the general government are on a national accounts basis. Debt data are end-of-year data for the general government in accordance with Maastricht

7/ Government expenditure in 2000 includes, as a negative entry, the proceeds from the sales of mobile phone licenses of euro 50.8 billion (2.5 percent of GDP). The proceeds also affect the financial (but not structural) balances and the government

$8 /$ Including supplementary trade items.

9/ Data for 2008 refer to October.

10/ Data for 2008 refer to the change to September.

11/ Data reflect Germany's contribution to M3 of the euro area; data not shown for 2002 because of a series break.

12/ Data for 2008 refer to October.

13/ Data for 2008 refer to October.

14/ Based on relative normalized unit labor cost in manufacturing. Data for 2008 refer to October. 
Table 2. Germany: foreign claims of banks on individual countries, November $20081 /$ (In billions of US dollars; unless otherwise specified)

\begin{tabular}{|c|c|c|c|c|c|}
\hline & \multirow[t]{2}{*}{$\mathrm{BIS} 2 /$} & \multicolumn{4}{|c|}{ Bundesbank Credit Registry 3/ } \\
\hline & & Total & Loans & $\begin{array}{c}\text { Credit } \\
\text { Derivatives } \\
\end{array}$ & $\begin{array}{c}\text { Share of } \\
\text { Credit } \\
\text { Derivatives } \\
\end{array}$ \\
\hline $\begin{array}{l}\text { All countries } \\
\text { in percent of total assets } \\
\text { in percent of GDP }\end{array}$ & $\begin{array}{r}4,135.7 \\
36.6 \\
165.4\end{array}$ & $\begin{array}{r}5,561.7 \\
49.2 \\
222.4\end{array}$ & $\begin{array}{r}4,619.3 \\
40.9 \\
184.7\end{array}$ & $\begin{array}{r}942.4 \\
8.3 \\
37.7\end{array}$ & 16.9 \\
\hline $\begin{array}{l}\text { Mature market countries } \\
\text { in percent of total assets } \\
\text { in percent of GDP }\end{array}$ & $\begin{array}{r}3,690.0 \\
32.6 \\
147.6\end{array}$ & $\begin{array}{r}4,934.8 \\
43.6 \\
197.3\end{array}$ & $\begin{array}{r}4,072.7 \\
36.0 \\
162.9\end{array}$ & $\begin{array}{r}862.1 \\
7.6 \\
34.5\end{array}$ & 17.5 \\
\hline $\begin{array}{l}\text { Emerging market countries } \\
\text { in percent of total assets } \\
\text { in percent of GDP }\end{array}$ & $\begin{array}{r}445.7 \\
3.9 \\
17.8\end{array}$ & $\begin{array}{r}584.1 \\
5.2 \\
23.4\end{array}$ & $\begin{array}{r}539.9 \\
4.8 \\
21.6\end{array}$ & $\begin{array}{r}44.2 \\
0.4 \\
1.8\end{array}$ & 7.6 \\
\hline $\begin{array}{l}\text { Africa \& Middle East } \\
\text { (in percent of total assets) } \\
\text { of which: }\end{array}$ & $\begin{array}{r}61.0 \\
0.5\end{array}$ & $\begin{array}{r}73.9 \\
0.7\end{array}$ & $\begin{array}{r}69.4 \\
0.6\end{array}$ & $\begin{array}{l}4.5 \\
0.0\end{array}$ & 6.1 \\
\hline Egypt & 4.7 & 5.6 & 5.6 & 0.1 & 0.9 \\
\hline Liberia & 9.2 & 9.3 & 9.2 & 0.1 & 1.2 \\
\hline South Africa & 7.5 & 7.9 & 6.9 & 1.1 & 13.5 \\
\hline Saudi Arabia & 3.1 & 5.7 & 5.3 & 0.4 & 6.8 \\
\hline United Arab Emirates & 10.9 & 12.5 & 11.6 & 1.0 & 7.8 \\
\hline $\begin{array}{l}\text { Asia \& Pacific } \\
\text { (in percent of total assets) } \\
\text { of which: }\end{array}$ & $\begin{array}{r}115.7 \\
1.0\end{array}$ & $\begin{array}{r}127.5 \\
1.1\end{array}$ & $\begin{array}{r}110.8 \\
1.0\end{array}$ & $\begin{array}{r}16.8 \\
0.1\end{array}$ & 13.2 \\
\hline China & 25.0 & 28.6 & 26.1 & 2.5 & 8.8 \\
\hline India & 23.2 & 26.6 & 23.7 & 2.9 & 10.8 \\
\hline Indonesia & 7.1 & 7.6 & 7.3 & 0.2 & 3.2 \\
\hline South Korea & 29.6 & 36.6 & 29.7 & 6.9 & 18.8 \\
\hline Taiwan, China & 5.6 & 4.6 & 3.7 & 0.9 & 19.8 \\
\hline $\begin{array}{l}\text { Central and Eastern Europe } \\
\text { (in percent of total assets) } \\
\text { of which: }\end{array}$ & $\begin{array}{r}229.0 \\
2.0\end{array}$ & $\begin{array}{r}196.7 \\
1.7\end{array}$ & $\begin{array}{r}186.3 \\
1.6\end{array}$ & $\begin{array}{r}10.4 \\
0.1\end{array}$ & 5.3 \\
\hline Czech Republic & 15.3 & 16.4 & 14.8 & 1.6 & 9.8 \\
\hline Hungary & 36.6 & 41.1 & 39.9 & 1.2 & 2.9 \\
\hline Latvia & 4.5 & 5.4 & 5.3 & 0.2 & 3.1 \\
\hline Lithuania & 4.6 & 4.2 & 4.2 & 0.0 & 0.1 \\
\hline Poland & 48.4 & 73.2 & 71.5 & 1.7 & 2.3 \\
\hline Romania & 5.2 & 6.1 & 6.1 & 0.1 & 0.9 \\
\hline Russia & 51.2 & 66.6 & 63.5 & 3.1 & 4.7 \\
\hline Slovakia & 4.0 & 4.7 & 4.5 & 0.2 & 5.2 \\
\hline Turkey & 18.8 & 31.0 & 27.1 & 3.9 & 12.6 \\
\hline Ukraine & 5.7 & 6.5 & 6.5 & 0.0 & 0.4 \\
\hline $\begin{array}{l}\text { Latin America/Caribbean } \\
\text { (in percent of total assets) } \\
\text { of which: }\end{array}$ & $\begin{array}{r}40.0 \\
0.4\end{array}$ & $\begin{array}{r}186.0 \\
1.6\end{array}$ & $\begin{array}{r}173.4 \\
1.5\end{array}$ & $\begin{array}{r}12.5 \\
0.1\end{array}$ & 6.7 \\
\hline Argentina & 2.9 & 4.1 & 4.0 & 0.1 & 3.5 \\
\hline Brazil & 18.0 & 19.8 & 17.5 & 2.4 & 12.0 \\
\hline Chile & 6.2 & 8.7 & 7.0 & 1.7 & 19.3 \\
\hline Mexico & 8.4 & 11.2 & 8.7 & 2.5 & 22.4 \\
\hline Venezuela & 1.1 & 2.2 & 1.9 & 0.3 & 13.2 \\
\hline \multicolumn{6}{|l|}{ Memorandum items: } \\
\hline Total bank assets & $11,305.9$ & & & & \\
\hline Nominal GDP & $2,500.8$ & & & & \\
\hline
\end{tabular}

Sources: BIS, Deutsche Bundesbank, ECB, IMF staff estimates.

*projected based on historical trend.

1/ Foreign claims include all international claims plus local claims of foreign affiliates in local currency.

The difference between the claims to all countries and the sum of mature and emerging market

exposures is due to offshore center exposures.

2/ BIS data is based on the consolidated lending statistic compiled by the Bundesbank (end-Sept. 2008).

$3 /$ The data are derived from the "Groß- und Millionenkreditmeldung" stipulated in $\S \S 13$ and

14 KWG (Credit Services Act). Under the Credit Services Act, debtors are obliged to register all loans (and other credit-like obligations) of EUR 1.5 million or higher with the Bundesbank on a quarterly basis. In this context, the definition of credit also included equity and counterparty risk exposure from credit default swaps (CDS).

Specific details on the obligation to register are stipulated in the Groß- und Millionenkreditverordnung

(GroMikV). Credit derivative exposures are recorded as off-shore transactions at their nominal value

if available, otherwise the book value applies. The presented data reflect gross amounts without recognition of collateral. 
Table 3. Germany: The Core Set of Financial Soundness Indicators for Banks, 1999-2007 (In percent)

\begin{tabular}{|c|c|c|c|c|c|c|c|c|c|}
\hline & 1999 & 2000 & 2001 & 2002 & 2003 & 2004 & 2005 & 2006 & 2007 \\
\hline \multicolumn{10}{|l|}{ Capital adequacy } \\
\hline Regulatory capital to risk-weighted assets & 10.8 & 10.9 & 11.2 & 11.9 & 12.4 & 12.4 & 12.2 & 12.5 & 12.9 \\
\hline Commercial banks & 10.9 & 11.3 & 12.0 & 12.7 & 12.8 & 12.5 & 11.6 & 12.5 & 13.3 \\
\hline Landesbanken & 9.9 & 10.0 & 10.4 & 11.5 & 13.0 & 12.2 & 12.1 & 11.7 & 11.6 \\
\hline Savings banks & 10.8 & 10.6 & 10.7 & 11.1 & 11.4 & 12.0 & 12.5 & 13.0 & 13.0 \\
\hline Credit cooperatives & 11.1 & 11.0 & 10.9 & 10.9 & 11.6 & 12.0 & 12.1 & 12.2 & 12.9 \\
\hline Regulatory Tier I capital to risk-weighted assets $1 /$ & 6.9 & 7.0 & 7.2 & 7.8 & 8.2 & 8.0 & 8.0 & 8.2 & 8.5 \\
\hline Commercial banks & 7.3 & 7.6 & 8.2 & 8.7 & 9.0 & 8.3 & 7.9 & 8.4 & 10.6 \\
\hline Landesbanken & 5.6 & 5.5 & 5.8 & 7.0 & 7.8 & 7.1 & 7.3 & 7.1 & 7.1 \\
\hline Savings banks & 7.0 & 6.9 & 7.0 & 7.2 & 7.4 & 7.7 & 8.0 & 8.4 & 8.4 \\
\hline Credit cooperatives & 7.2 & 7.3 & 7.3 & 7.5 & 8.0 & 8.3 & 8.5 & 9.1 & 8.7 \\
\hline \multicolumn{10}{|l|}{ Asset composition and quality } \\
\hline \multicolumn{10}{|l|}{ Sectoral distribution of loans to total loans } \\
\hline Loan to households & 31.2 & 30.6 & 29.7 & 29.5 & 29.7 & 29.3 & 28.5 & 27.6 & 25.6 \\
\hline Commercial banks & 31.0 & 29.2 & 27.5 & 26.8 & 26.1 & 25.8 & 24.8 & 23.9 & 21.8 \\
\hline Landesbanken & 8.3 & 8.2 & 7.9 & 7.5 & 7.5 & 7.1 & 6.8 & 6.2 & 5.2 \\
\hline Savings banks & 63.8 & 63.6 & 62.4 & 61.9 & 62.9 & 62.3 & 62.2 & 61.1 & 58.2 \\
\hline Credit cooperatives & 66.6 & 68.0 & 66.4 & 67.0 & 68.1 & 68.3 & 69.3 & 68.5 & 66.3 \\
\hline Loans to non-financial corporations & 17.3 & 17.4 & 17.1 & 16.6 & 16.0 & 15.2 & 14.5 & 14.3 & 14.1 \\
\hline Commercial banks & 22.3 & 20.7 & 19.3 & 17.7 & 15.6 & 14.3 & 13.3 & 12.6 & 12.4 \\
\hline Landesbanken & 18.9 & 19.5 & 19.7 & 18.9 & 18.5 & 17.8 & 16.7 & 17.0 & 16.2 \\
\hline Savings banks & 17.7 & 18.5 & 18.8 & 18.6 & 18.3 & 18.0 & 17.6 & 17.3 & 17.6 \\
\hline Credit cooperatives & 13.0 & 13.6 & 13.4 & 13.2 & 12.9 & 12.4 & 12.0 & 12.1 & 12.4 \\
\hline NPLs to gross loans & 4.1 & 4.6 & 4.5 & 5.0 & 5.2 & 4.9 & 4.0 & 3.4 & 2.7 \\
\hline Commercial banks & 5.0 & 5.7 & 5.2 & 5.2 & 5.1 & 4.5 & 3.3 & 2.6 & 1.8 \\
\hline Landesbanken & 2.5 & 2.7 & 2.8 & 3.7 & 4.4 & 4.1 & 2.9 & 2.0 & 1.5 \\
\hline Savings banks & 5.7 & 5.6 & 5.9 & 6.4 & 6.8 & 6.9 & 6.6 & 5.9 & 5.1 \\
\hline Credit cooperatives & 6.4 & 6.9 & 7.2 & 8.0 & 8.1 & 8.2 & 7.3 & 6.6 & 5.5 \\
\hline NPLs net of provisions to capital & 38.6 & 44.0 & 45.4 & 47.8 & 50.4 & 44.5 & 34.6 & $28,6^{* *}$ & 22.7 \\
\hline Commercial banks & 38.5 & 40.7 & 51.2 & 47.2 & 54.5 & 41.2 & 30.6 & $24,6^{* *}$ & 15.5 \\
\hline Landesbanken 2/ & 26.0 & 29.6 & 27.9 & 31.6 & 34.9 & 37.4 & 25.0 & $16.1^{\text {a) }}$ & 11.3 \\
\hline Savings banks & 51.6 & 49.2 & 52.1 & 53.6 & 58.0 & 54.2 & 50.4 & $43,6^{* *}$ & 35.4 \\
\hline Credit cooperatives & 49.7 & 51.9 & 53.5 & 61.0 & 58.3 & 57.2 & 49.0 & 43.0 & 35.9 \\
\hline \multicolumn{10}{|l|}{ Earnings and profitability } \\
\hline Return on average assets (after-tax) & 0.2 & 0.2 & 0.2 & 0.1 & -0.1 & 0.1 & 0.3 & 0.3 & 0.2 \\
\hline Commercial banks & 0.3 & 0.3 & 0.2 & 0.0 & -0.3 & -0.1 & 0.5 & 0.3 & 0.5 \\
\hline Landesbanken & 0.1 & 0.1 & 0.1 & 0.1 & -0.2 & 0.0 & 0.2 & 0.3 & 0.0 \\
\hline Savings banks & 0.2 & 0.3 & 0.2 & 0.2 & 0.2 & 0.2 & 0.3 & 0.2 & 0.2 \\
\hline Credit cooperatives & 0.2 & 0.2 & 0.2 & 0.3 & 0.3 & 0.3 & 0.5 & 0.5 & 0.3 \\
\hline Return on average equity (after-tax) & 6.5 & 6.1 & 4.6 & 2.9 & -1.5 & 1.9 & 9.2 & 7.5 & 4.7 \\
\hline Commercial banks & 7.0 & 7.3 & 4.2 & 0.0 & -6.6 & -1.4 & 15.5 & 9.1 & 15.6 \\
\hline Landesbanken & 5.9 & 4.2 & 4.0 & 1.9 & -5.2 & -0.8 & 5.6 & 9.7 & 0.9 \\
\hline Savings banks & 6.1 & 6.1 & 5.1 & 4.7 & 4.0 & 5.0 & 5.6 & 5.0 & 4.2 \\
\hline Credit cooperatives & 4.7 & 4.1 & 4.4 & 6.6 & 5.2 & 5.3 & 9.0 & 8.5 & 5.1 \\
\hline Interest margin to gross income & 73.2 & 67.8 & 69.8 & 73.4 & 70.2 & 73.5 & 68.2 & 68.2 & 72.9 \\
\hline Commercial banks & 61.7 & 52.7 & 56.2 & 63.7 & 56.5 & 64.9 & 55.3 & 61.8 & 66.3 \\
\hline Landesbanken & 77.6 & 72.4 & 75.0 & 75.8 & 79.0 & 79.4 & 83.2 & 70.3 & 91.6 \\
\hline Savings banks & 81.3 & 80.9 & 80.8 & 81.3 & 80.6 & 79.6 & 79.0 & 77.7 & 75.1 \\
\hline Credit cooperatives & 77.1 & 76.5 & 78.3 & 79.1 & 75.4 & 75.5 & 74.7 & 65.3 & 71.3 \\
\hline Noninterest expenses to gross income & 66.0 & 68.4 & 71.4 & 67.2 & 66.5 & 65.5 & 61.0 & 62.3 & 65.0 \\
\hline Commercial banks & 73.9 & 75.4 & 80.4 & 74.2 & 74.0 & 73.5 & 59.8 & 66.0 & 65.5 \\
\hline Landesbanken & 54.8 & 55.9 & 57.1 & 56.1 & 53.1 & 53.5 & 59.3 & 53.6 & 61.3 \\
\hline Savings banks & 65.7 & 68.9 & 69.9 & 66.5 & 66.4 & 64.9 & 66.0 & 65.8 & 69.5 \\
\hline Credit cooperatives & 71.2 & 74.5 & 76.7 & 73.1 & 69.6 & 68.7 & 70.0 & 64.3 & 70.5 \\
\hline \multicolumn{10}{|l|}{ Liquidity } \\
\hline Liquid assets to total short-term liabilities 2/ & $\ldots$ & 120.9 & 121.1 & 121.0 & 123.5 & 124.4 & 122.0 & 120.9 & 119.4 \\
\hline Commercial banks & $\ldots$ & 109.0 & 111.0 & 110.9 & 111.7 & 110.2 & 110.7 & 111.8 & 113.0 \\
\hline Landesbanken & $\ldots$ & 110.2 & 104.0 & 107.1 & 115.5 & 129.9 & 122.4 & 118.8 & 115.5 \\
\hline Savings banks & $\ldots$ & 202.5 & 212.6 & 211.6 & 207.8 & 221.6 & 224.2 & 206.9 & 190.9 \\
\hline Credit cooperatives & $\ldots$ & 178.8 & 184.0 & 193.4 & 189.6 & 193.4 & 181.4 & 174.8 & 167.1 \\
\hline \multicolumn{10}{|l|}{ Sensitivity to market risk } \\
\hline Net open positions in FX to capital & 11.3 & 11.0 & 10.7 & 11.4 & 6.7 & 6.9 & 6.9 & 6.7 & 6.9 \\
\hline Commercial banks & 11.9 & 7.3 & 7.2 & 5.2 & 6.1 & 4.4 & 5.7 & 10.1 & 6.2 \\
\hline Landesbanken & 10.1 & 11.7 & 11.6 & 14.7 & 4.6 & 6.7 & 5.6 & 4.2 & 6.6 \\
\hline Savings banks & 11.9 & 13.6 & 14.3 & 13.8 & 12.2 & 11.1 & 11.7 & 10.1 & 10.9 \\
\hline Credit cooperatives & 19.7 & 21.8 & 21.7 & 20.8 & 16.1 & 15.6 & 14.0 & 11.3 & 10.7 \\
\hline
\end{tabular}

Source: Deutsche Bundesbank. The authorities provide annual data only and disseminate them once a

${ }^{*}$ A methodological break in the supervisory time series on the capital adequacy of German banks has taken place in 2007 due to substantial changes in the regulatory reporting framework, following Basel II.

1/ 1998-2006 according to Capital Adequacy Regulation, Principle I. Since 2007 according to Solvency Regulation.

${ }^{\star *}$ Revised data.

2/ 2000-2007 data compiled in accordance with IMF's FSI Compilation Guide. Data not available before July 1, 2000

a) Due to one off data availability, comparability of 2006 data with other years limited. 
Table 4. Germany: Encouraged and Other Financial Soundness Indicators, 1999-2007

(In percent, unless otherwise indicated)

\begin{tabular}{|c|c|c|c|c|c|c|c|c|c|}
\hline & 1999 & 2000 & 2001 & 2002 & 2003 & 2004 & 2005 & 2006 & 2007 \\
\hline \multicolumn{10}{|l|}{ Corporate sector } \\
\hline Total debt to equity $1 /$ & 81.0 & 98.0 & 106.5 & 153.6 & 131.6 & 121.8 & 111.6 & 103.2 & 96.5 \\
\hline Total debt to GDP 2/ & 145.5 & 160.7 & 163.4 & 165.9 & 164.1 & 155.1 & 153.7 & 155.4 & 158.0 \\
\hline Return on invested capital 3/ 4/ & 6.5 & 6.3 & 7.4 & 8.7 & 8.3 & 8.9 & 9.0 & 8.6 & 8.5 \\
\hline Earnings to interest and principal expenses $1 / 5 /$ & 561.9 & 495.6 & 513.8 & 536.9 & 570.8 & 715.3 & 748.1 & 762.0 & 756.0 \\
\hline Number of applications for protection from creditors $1 / 6$ / & 18,006 & 18,389 & 21,019 & 23,642 & 23,840 & 22,474 & 19,540 & 16,408 & 13,599 \\
\hline \multicolumn{10}{|l|}{ Deposit-taking institutions } \\
\hline Capital to assets & 3.7 & 3.7 & 3.8 & 4.1 & 4.2 & 4.0 & 4.1 & 4.3 & 4.3 \\
\hline Commercial banks & 5.0 & 4.7 & 4.9 & 5.2 & 5.0 & 4.4 & 4.4 & 4.4 & 4.3 \\
\hline Landesbanken & 3.3 & 3.4 & 3.8 & 3.8 & 4.0 & 4.0 & 4.0 & 3.9 & 3.8 \\
\hline Savings banks & 3.8 & 3.9 & 4.0 & 4.2 & 4.3 & 4.5 & 4.6 & 4.8 & 5.0 \\
\hline Credit cooperatives & 4.6 & 4.9 & 4.7 & 4.9 & 5.1 & 5.3 & 5.4 & 5.7 & 5.5 \\
\hline \multicolumn{10}{|l|}{ Geographical distribution of loans to total loans } \\
\hline Germany & 85.4 & 83.6 & 81.3 & 80.0 & 78.6 & 76.8 & 75.2 & 72.6 & 71.1 \\
\hline EU-member countries & 8.6 & 9.6 & 11.6 & 13.2 & 14.6 & 16.9 & 17.3 & 19.5 & 20.4 \\
\hline Others & 6.0 & 6.8 & 7.1 & 6.8 & 6.8 & 6.3 & 7.5 & 7.9 & 8.5 \\
\hline FX loans to total loans & 7.8 & 9.3 & 10.2 & 9.6 & 9.1 & 9.6 & 10.2 & 10.5 & 11.5 \\
\hline Personnel expenses to noninterest expenses & 54.8 & 54.1 & 53.1 & 53.1 & 53.8 & 54.4 & 55.1 & 56.4 & 54.7 \\
\hline Commercial banks & 51.3 & 50.4 & 49.2 & 48.5 & 49.4 & 49.7 & 50.7 & 52.5 & 51.7 \\
\hline Landesbanken & 51.0 & 51.9 & 49.8 & 49.6 & 49.0 & 50.2 & 50.5 & 55 & 51.7 \\
\hline Savings banks & 59.9 & 60.0 & 59.3 & 59.5 & 60.6 & 61.3 & 61.8 & 61.5 & 58.5 \\
\hline Credit cooperatives & 58.5 & 57.8 & 58.4 & 59.0 & 59.0 & 59.2 & 60.1 & 60.9 & 59.8 \\
\hline Trading and fee income to total income & 26.8 & 32.2 & 30.2 & 26.6 & 29.8 & 26.5 & 31.8 & 31.8 & 27.1 \\
\hline Commercial banks & 38.3 & 47.3 & 43.8 & 36.3 & 43.5 & 35.1 & 44.7 & 38.2 & 33.7 \\
\hline Landesbanken & 22.4 & 27.6 & 25.0 & 24.2 & 21.0 & 20.6 & 16.8 & 29.7 & 8.4 \\
\hline Savings banks & 18.7 & 19.1 & 19.2 & 18.7 & 19.4 & 20.4 & 21.0 & 22.3 & 24.9 \\
\hline Credit cooperatives & 22.9 & 23.5 & 21.7 & 20.9 & 24.6 & 24.5 & 25.3 & 34.7 & 28.7 \\
\hline Customer deposits to total (non-interbank) loans & 63.5 & 63.9 & 64.0 & 65.4 & 67.1 & 70.0 & 71.8 & 75.2 & 76.2 \\
\hline Commercial banks & 62.6 & 63.0 & 68.6 & 74.2 & 78.4 & 85.3 & 85.5 & 95.7 & 92.6 \\
\hline Landesbanken & 35.2 & 38.4 & 34.3 & 30.1 & 32.8 & 35.4 & 40.6 & 42.9 & 45.7 \\
\hline Savings banks & 104.7 & 101.8 & 101.1 & 100.3 & 99.8 & 101.0 & 102.2 & 103.3 & 105.4 \\
\hline Credit cooperatives & 113.6 & 108.0 & 110.3 & 110.8 & 111.7 & 113.2 & 113.6 & 113.1 & 114.7 \\
\hline Spread between highest and lowest interbank rates $7 /$ & $\ldots$ & $\ldots$ & $\ldots$ & $\ldots$ & $\ldots$ & $\ldots$ & 2.0 & 2.6 & 4.6 \\
\hline Spread between reference loan and deposit rates $8 /$ & $\ldots$ & $\ldots$ & $\ldots$ & $\ldots$ & 379 & 366 & 353 & 317 & 285 \\
\hline \multicolumn{10}{|l|}{ Insurance sector } \\
\hline Solvency ratio, Life & $\ldots$ & $\cdots$ & 199 & 170 & 176 & 177 & 190 & 203.8 & n.a. \\
\hline Solvency ratio, Non-life & $\ldots$ & 350 & 343 & 337 & 346 & 286 & 255 & 310.7 & n.a. \\
\hline Return on average equity, Life 9/ & 11.4 & 12.5 & 7.0 & 3.4 & 5.7 & 5.8 & 9.7 & 9.5 & n.a. \\
\hline Return on average equity, Non-life 9/ & 7.3 & 8.7 & 8.9 & 2.8 & 4.1 & 3.0 & 4.5 & 4.6 & n.a. \\
\hline \multicolumn{10}{|l|}{ Market liquidity } \\
\hline Average bid-ask spread in the securities market (government bills) & $\ldots$ & $\ldots$ & $\cdots$ & $\ldots$ & $\cdots$ & $\cdots$ & 0.0 & 0.0 & 0.0 \\
\hline Average bid-ask spread in the securities market (corporate securities) & $\ldots$ & $\ldots$ & $\ldots$ & $\ldots$ & $\ldots$ & $\ldots$ & 0.1 & 0.1 & 0.1 \\
\hline \multicolumn{10}{|l|}{ Households } \\
\hline Household debt to GDP 1/ & 72.9 & 73.4 & 72.7 & 72.4 & 72.5 & 71.2 & 69.9 & 67.4 & 63.8 \\
\hline Household debt service and principal payments to income 1/ 5/ & 4.7 & 5.1 & 5.0 & 4.7 & 4.2 & 3.9 & 3.7 & 3.8 & 4.1 \\
\hline \multicolumn{10}{|l|}{ Real estate markets } \\
\hline Real estate prices, new dwellings $10 /$ & 99 & 100 & 101 & 102 & 100 & 100 & 100 & 101 & 102 \\
\hline Real estate prices, resale $10 /$ & 108 & 108 & 108 & 105 & 104 & 102 & 100 & 100 & 100 \\
\hline Residential real estate loans to total loans & 16.2 & 16.4 & 16.1 & 16.2 & 18.0 & 17.8 & 17.8 & 17.7 & 16.5 \\
\hline Commercial real estate loans to total loans & 6.4 & 6.4 & 6.2 & 6.2 & 6.6 & 6.4 & 6.1 & 5.8 & 5.4 \\
\hline
\end{tabular}

Source: Deutsche Bundesbank. The authorities provide annual data only and disseminate them once a year.

1/ Indicator compiled according to definitions of the Compilation Guide on FSIs.

2/ Total debt to corporate gross value added.

3/ Return defined as net operating income less taxes, where net operating income and taxes are

compiled according to the FSI Compilation Guide.

4/ Invested capital estimated as balance sheet total less other accounts payable (AF.7 according to ESA 1995).

5/ Excluding principal payments.

6/ Resident enterprises that filed for bankruptcy.

7/ Spread between highest and lowest three month money market rates as reported by Frankfurt banks (basis points)

8/ Spread in basis points.

9/ Profits after tax devided by equity.

10/ Residential property index (yearly average, $2005=100$ ); aggregation of data for new dwellings and resale is not available. 
Table 5. Germany: Medium-Term Balance of Payments, 2005-13

\begin{tabular}{|c|c|c|c|c|c|c|c|c|c|}
\hline & \multirow[b]{2}{*}{2005} & \multirow[b]{2}{*}{2006} & \multicolumn{7}{|c|}{ Projections } \\
\hline & & & 2007 & 2008 & 2009 & 2010 & 2011 & 2012 & 2013 \\
\hline & \multicolumn{9}{|c|}{ (In billions of Euros, unless otherwise indicated) } \\
\hline Current account & 117 & 141 & 184 & 183 & 155 & 141 & 144 & 159 & 180 \\
\hline In percent of GDP & 5.2 & 6.1 & 7.6 & 7.3 & 6.2 & 5.6 & 5.5 & 6.0 & 6.5 \\
\hline Trade balance & 144 & 146 & 189 & 205 & 196 & 187 & 189 & 205 & 233 \\
\hline Exports & 791 & 904 & 987 & 1,039 & 1,031 & 1,077 & 1,135 & 1,214 & 1,317 \\
\hline Imports & -646 & -758 & -798 & -835 & -835 & -890 & -946 & $-1,009$ & $-1,084$ \\
\hline Nonfactor services & -25 & -16 & -16 & -16 & -21 & -24 & -26 & -29 & -34 \\
\hline Exports & 134 & 152 & 161 & 162 & 159 & 166 & 175 & 187 & 203 \\
\hline Imports & -159 & -168 & -178 & -178 & -180 & -190 & -201 & -216 & -237 \\
\hline Balance on Factor Income & 26 & 38 & 42 & 27 & 13 & 11 & 15 & 16 & 14 \\
\hline Credit & 161 & 195 & 232 & 207 & 180 & 216 & 239 & 248 & 254 \\
\hline Debit & -135 & -158 & -190 & -180 & -167 & -206 & -224 & -232 & -240 \\
\hline Current transfers, net & -29 & -27 & -31 & -33 & -33 & -33 & -34 & -32 & -33 \\
\hline Capital and financial accounts & -136 & -156 & -225 & -183 & -155 & -141 & -144 & -159 & -180 \\
\hline Capital account, net & -1 & 0 & 0 & 0 & 0 & 0 & 0 & 0 & 0 \\
\hline FDI, net & -22 & -32 & -85 & -57 & -33 & -27 & -27 & -28 & -29 \\
\hline Portfolio investment, net & -40 & -17 & 63 & 65 & 65 & 66 & 68 & 70 & 72 \\
\hline Other & -75 & -111 & -203 & -191 & -187 & -181 & -184 & -201 & -223 \\
\hline Reserve assets & 2 & 3 & -1 & 0 & 0 & 0 & 0 & 0 & 0 \\
\hline Errors and omissions & 19 & 15 & 41 & 0 & 0 & 0 & 0 & 0 & 0 \\
\hline
\end{tabular}

Source: WEO. 
Table 6. General Government: Government Operations

\begin{tabular}{|c|c|c|c|c|c|c|c|c|c|c|}
\hline & 2004 & 2005 & 2006 & 2007 & $\begin{array}{l}2008 \\
\text { Proj. }\end{array}$ & $\begin{array}{l}2009 \\
\text { Proj. }\end{array}$ & $\begin{array}{c}2010 \\
\text { Proj. }\end{array}$ & $\begin{array}{c}2011 \\
\text { Proj. }\end{array}$ & $\begin{array}{c}2012 \\
\text { Proj. }\end{array}$ & $\begin{array}{c}2013 \\
\text { Proj. }\end{array}$ \\
\hline \multicolumn{11}{|c|}{ (in billions of euros) } \\
\hline Revenue & 958 & 976 & 1,016 & 1,065 & 1,098 & 1,102 & 1,108 & 1,134 & 1,174 & 1,215 \\
\hline Current revenue & 948 & 966 & 1,007 & 1,055 & 1,088 & 1,093 & 1,098 & 1,123 & 1,162 & 1,203 \\
\hline Taxes & 481 & 493 & 531 & 576 & 589 & 590 & 588 & 600 & 621 & 641 \\
\hline Indirect taxes & 260 & 266 & 280 & 305 & 312 & 313 & 318 & 325 & 335 & 345 \\
\hline Direct taxes & 221 & 228 & 250 & 271 & 277 & 277 & 270 & 275 & 286 & 296 \\
\hline Social contributions & 397 & 396 & 400 & 400 & 420 & 425 & 431 & 442 & 457 & 473 \\
\hline Grants & 10 & 10 & 9 & 10 & 10 & 10 & 10 & 11 & 11 & 12 \\
\hline Other current revenue & 70 & 77 & 77 & 79 & 79 & 77 & 79 & 80 & 85 & 89 \\
\hline Expense & 1,010 & 1,019 & 1,020 & 1,033 & 1,061 & 1,091 & 1,113 & 1,137 & 1,161 & 1,191 \\
\hline Compensation of employees & 170 & 169 & 167 & 168 & 176 & 181 & 182 & 187 & 189 & 193 \\
\hline Goods and services & 91 & 95 & 98 & 102 & 104 & 106 & 107 & 108 & 108 & 109 \\
\hline Interest & 62 & 62 & 65 & 67 & 64 & 63 & 66 & 66 & 67 & 69 \\
\hline Subsidies & 29 & 27 & 27 & 27 & 28 & 29 & 24 & 24 & 25 & 25 \\
\hline Social benefits & 592 & 597 & 598 & 597 & 619 & 643 & 663 & 681 & 699 & 718 \\
\hline Other expense & 66 & 69 & 64 & 72 & 69 & 69 & 70 & 72 & 74 & 76 \\
\hline Gross operating balance & -52 & -43 & -3 & 31 & 37 & 12 & -6 & -4 & 13 & 24 \\
\hline Net acquisition of nonfinancial assets & 32 & 31 & 33 & 36 & 36 & 38 & 39 & 39 & 40 & 41 \\
\hline Net lending / borrowing & -84 & -74 & -36 & -4 & 1 & -27 & -45 & -42 & -27 & -17 \\
\hline Net acquisition of financial assets & -12 & -5 & 11 & 9 & $\ldots$ & $\ldots$ & $\ldots$ & $\ldots$ & $\ldots$ & $\ldots$ \\
\hline Net acquisition of financial liabilities & 72 & 70 & 49 & 9 & $\ldots$ & $\ldots$ & $\ldots$ & $\ldots$ & $\ldots$ & $\ldots$ \\
\hline \multicolumn{11}{|c|}{ (in percent of GDP) } \\
\hline Revenue & 43.3 & 43.5 & 43.8 & 43.9 & 44.0 & 44.1 & 43.7 & 43.7 & 44.0 & 44.1 \\
\hline Taxes & 21.8 & 22.0 & 22.9 & 23.8 & 23.6 & 23.6 & 23.2 & 23.1 & 23.2 & 23.3 \\
\hline Indirect taxes & 11.8 & 11.8 & 12.1 & 12.6 & 12.5 & 12.5 & 12.5 & 12.5 & 12.5 & 12.5 \\
\hline Direct taxes & 10.0 & 10.1 & 10.8 & 11.2 & 11.1 & 11.1 & 10.6 & 10.6 & 10.7 & 10.8 \\
\hline Social contributions & 17.9 & 17.7 & 17.2 & 16.5 & 16.8 & 17.0 & 17.0 & 17.0 & 17.1 & 17.2 \\
\hline Grants & 0.4 & 0.4 & 0.4 & 0.4 & 0.4 & 0.4 & 0.4 & 0.4 & 0.4 & 0.4 \\
\hline Other current revenue & 3.2 & 3.4 & 3.3 & 3.3 & 3.2 & 3.1 & 3.1 & 3.1 & 3.2 & 3.2 \\
\hline Expense & 45.7 & 45.4 & 43.9 & 42.6 & 42.5 & 43.6 & 43.9 & 43.8 & 43.5 & 43.3 \\
\hline Compensation of employees & 7.7 & 7.5 & 7.2 & 6.9 & 7.1 & 7.3 & 7.2 & 7.2 & 7.1 & 7.0 \\
\hline Goods and services & 4.1 & 4.3 & 4.2 & 4.2 & 4.2 & 4.2 & 4.2 & 4.2 & 4.0 & 4.0 \\
\hline Interest & 2.8 & 2.8 & 2.8 & 2.8 & 2.6 & 2.5 & 2.6 & 2.5 & 2.5 & 2.5 \\
\hline Subsidies & 1.3 & 1.2 & 1.2 & 1.1 & 1.1 & 1.1 & 1.0 & 0.9 & 0.9 & 0.9 \\
\hline Social benefits & 26.8 & 26.6 & 25.8 & 24.6 & 24.8 & 25.7 & 26.1 & 26.2 & 26.2 & 26.1 \\
\hline Other expense & 3.0 & 3.1 & 2.8 & 3.0 & 2.8 & 2.8 & 2.8 & 2.8 & 2.8 & 2.8 \\
\hline Gross operating balance & -2.3 & -1.9 & -0.1 & 1.3 & 1.5 & 0.5 & -0.2 & -0.1 & 0.5 & 0.9 \\
\hline Net acquisition of nonfinancial assets & 1.4 & 1.4 & 1.4 & 1.5 & 1.5 & 1.5 & 1.5 & 1.5 & 1.5 & 1.5 \\
\hline Net lending/borrowing & -3.8 & -3.3 & -1.5 & -0.2 & 0.0 & -1.1 & -1.8 & -1.6 & -1.0 & -0.6 \\
\hline Primary balance & -1.0 & -0.5 & 1.3 & 2.6 & 2.6 & 1.5 & 0.8 & 0.9 & 1.5 & 1.9 \\
\hline Net acquisition of financial assets & -0.5 & -0.2 & 0.5 & 0.4 & $\ldots$ & $\ldots$ & $\ldots$ & $\ldots$ & $\ldots$ & $\ldots$ \\
\hline Net acquisition of financial liabilities & 3.2 & 3.1 & 2.1 & 0.4 & $\ldots$ & $\ldots$ & $\ldots$ & $\ldots$ & $\ldots$ & $\ldots$ \\
\hline \multicolumn{11}{|l|}{ Memorandum item: } \\
\hline Structural balance & -2.6 & -2.2 & -1.2 & -0.2 & -0.5 & -0.6 & -1.0 & -1.0 & -0.6 & -0.4 \\
\hline Change in structural balance due to legislative & -0.5 & -0.3 & 1.1 & 0.3 & -0.5 & -0.2 & -0.4 & 0.0 & 0.0 & 0.0 \\
\hline Expense and net acquisition of nonfinancial as & 47.1 & 46.8 & 45.3 & 44.1 & 44.0 & 45.2 & 45.4 & 45.3 & 45.0 & 44.7 \\
\hline Public gross debt (Maastricht definition) & 65.6 & 67.8 & 67.6 & 65.0 & 68.4 & 72.1 & 72.8 & 72.2 & 71.5 & 70.8 \\
\hline
\end{tabular}


Table 6. General Government: Balance Sheet (concluded)

\begin{tabular}{|c|c|c|c|c|c|c|c|c|c|c|}
\hline & 2004 & 2005 & $\begin{array}{l}2006 \\
\text { Proj. }\end{array}$ & $\begin{array}{c}2007 \\
\text { Proj. }\end{array}$ & $\begin{array}{l}2008 \\
\text { Proj. }\end{array}$ & $\begin{array}{l}2009 \\
\text { Proj. }\end{array}$ & $\begin{array}{l}2010 \\
\text { Proj. }\end{array}$ & $\begin{array}{l}2011 \\
\text { Proj. }\end{array}$ & $\begin{array}{l}2012 \\
\text { Proj. }\end{array}$ & $\begin{array}{l}2013 \\
\text { Proj. }\end{array}$ \\
\hline \multicolumn{11}{|c|}{ (in billions of euros) } \\
\hline Net financial worth & $-1,047$ & $-1,116$ & $-1,117$ & $-1,080$ & $\ldots$ & $\ldots$ & $\ldots$ & $\ldots$ & $\ldots$ & $\ldots$ \\
\hline Financial assets & 466 & 475 & 494 & 508 & $\ldots$ & $\ldots$ & $\ldots$ & $\ldots$ & $\ldots$ & $\ldots$ \\
\hline Currency and Deposits & 148 & 154 & 190 & 201 & $\ldots$ & $\ldots$ & $\ldots$ & $\ldots$ & $\ldots$ & $\ldots$ \\
\hline Securities and shares & 149 & 165 & 175 & 178 & $\ldots$ & $\ldots$ & $\ldots$ & $\ldots$ & $\ldots$ & $\ldots$ \\
\hline Loans & 73 & 65 & 60 & 59 & $\ldots$ & $\ldots$ & $\ldots$ & $\ldots$ & $\ldots$ & $\ldots$ \\
\hline Other assets & 96 & 91 & 69 & 71 & $\ldots$ & $\ldots$ & $\ldots$ & $\ldots$ & $\ldots$ & $\ldots$ \\
\hline Financial liabilities & 1,513 & 1,592 & 1,611 & 1,588 & $\ldots$ & $\ldots$ & $\ldots$ & $\ldots$ & $\ldots$ & $\ldots$ \\
\hline Currency and deposits & 6 & 6 & 6 & 7 & $\ldots$ & $\ldots$ & $\ldots$ & $\ldots$ & $\ldots$ & $\ldots$ \\
\hline Securities and shares & 1,049 & 1,126 & 1,151 & 1,152 & $\ldots$ & $\ldots$ & $\ldots$ & $\ldots$ & $\ldots$ & $\ldots$ \\
\hline Loans & 455 & 456 & 449 & 426 & $\ldots$ & $\ldots$ & $\ldots$ & $\ldots$ & $\ldots$ & $\ldots$ \\
\hline Other liabilities & 4 & 4 & 4 & 4 & $\ldots$ & $\ldots$ & $\ldots$ & $\ldots$ & $\ldots$ & $\ldots$ \\
\hline Transactions, net & -84 & -76 & -38 & 0 & $\ldots$ & $\ldots$ & $\ldots$ & $\ldots$ & $\ldots$ & $\ldots$ \\
\hline Financial assets & -12 & -5 & 11 & 9 & $\ldots$ & $\ldots$ & $\ldots$ & $\ldots$ & $\ldots$ & $\ldots$ \\
\hline Currency and Deposits & -5 & 5 & 36 & 10 & $\ldots$ & $\ldots$ & $\ldots$ & $\ldots$ & $\ldots$ & $\ldots$ \\
\hline Securities and shares & -7 & 3 & 0 & 2 & $\ldots$ & $\ldots$ & $\ldots$ & $\ldots$ & $\ldots$ & $\ldots$ \\
\hline Loans & -7 & -7 & -5 & -1 & $\ldots$ & $\ldots$ & $\ldots$ & $\ldots$ & $\ldots$ & $\ldots$ \\
\hline Other assets & 7 & -6 & -20 & -2 & $\ldots$ & $\ldots$ & $\ldots$ & $\ldots$ & $\ldots$ & $\ldots$ \\
\hline Financial liabilities & 72 & 70 & 49 & 9 & $\ldots$ & $\ldots$ & $\ldots$ & $\ldots$ & $\ldots$ & $\ldots$ \\
\hline Currency and deposits & 1 & 1 & 1 & 1 & $\ldots$ & $\ldots$ & $\ldots$ & $\ldots$ & $\ldots$ & $\ldots$ \\
\hline Securities other than shares & 69 & 70 & 53 & 30 & $\ldots$ & $\ldots$ & $\ldots$ & $\ldots$ & $\ldots$ & $\ldots$ \\
\hline Loans & 1 & 1 & -6 & -22 & $\ldots$ & $\ldots$ & $\ldots$ & $\ldots$ & $\ldots$ & $\ldots$ \\
\hline Other liabilities & 1 & -1 & 2 & 0 & $\ldots$ & $\ldots$ & $\ldots$ & $\ldots$ & $\ldots$ & $\ldots$ \\
\hline Other economic flows, net & -20 & 6 & 37 & 37 & $\ldots$ & $\ldots$ & $\ldots$ & $\ldots$ & $\ldots$ & $\ldots$ \\
\hline Financial assets & 7 & 14 & 7 & 6 & $\ldots$ & $\ldots$ & $\ldots$ & $\ldots$ & $\ldots$ & $\ldots$ \\
\hline Currency and Deposits & -1 & 0 & 0 & 1 & $\ldots$ & $\ldots$ & $\ldots$ & $\ldots$ & $\ldots$ & $\ldots$ \\
\hline Securities and shares & 6 & 13 & 9 & 1 & $\ldots$ & $\ldots$ & $\ldots$ & $\ldots$ & $\ldots$ & $\ldots$ \\
\hline Loans & 0 & 0 & -1 & 0 & $\ldots$ & $\ldots$ & $\ldots$ & $\ldots$ & $\ldots$ & $\ldots$ \\
\hline Other assets & 2 & 1 & -1 & 3 & $\ldots$ & $\ldots$ & $\ldots$ & $\ldots$ & $\ldots$ & $\ldots$ \\
\hline Financial liabilities & 27 & 8 & -30 & -31 & $\ldots$ & $\ldots$ & $\ldots$ & $\ldots$ & $\ldots$ & $\ldots$ \\
\hline Currency and deposits & 0 & 0 & 0 & 0 & $\ldots$ & $\ldots$ & $\ldots$ & $\ldots$ & $\ldots$ & $\ldots$ \\
\hline Securities other than shares & 29 & 8 & -28 & -29 & $\ldots$ & $\ldots$ & $\ldots$ & $\ldots$ & $\ldots$ & $\ldots$ \\
\hline Loans & -1 & 0 & 0 & -1 & $\ldots$ & $\ldots$ & $\ldots$ & $\ldots$ & $\ldots$ & $\ldots$ \\
\hline Other liabilities & -1 & 1 & -2 & -1 & $\ldots$ & $\cdots$ & $\cdots$ & $\cdots$ & $\cdots$ & $\cdots$ \\
\hline \multicolumn{11}{|c|}{ (in percent of GDP) } \\
\hline Net financial worth & -47.4 & -49.8 & -48.1 & -44.6 & $\cdots$ & $\cdots$ & $\cdots$ & $\cdots$ & $\cdots$ & $\cdots$ \\
\hline Financial assets & 21.1 & 21.2 & 21.3 & 21.0 & $\ldots$ & $\ldots$ & $\ldots$ & $\ldots$ & $\ldots$ & $\ldots$ \\
\hline Currency and Deposits & 6.7 & 6.8 & 8.2 & 8.3 & $\ldots$ & $\ldots$ & $\ldots$ & $\ldots$ & $\ldots$ & $\ldots$ \\
\hline Securities and shares & 6.7 & 7.4 & 7.5 & 7.3 & $\ldots$ & $\ldots$ & $\ldots$ & $\ldots$ & $\ldots$ & $\ldots$ \\
\hline Loans & 3.3 & 2.9 & 2.6 & 2.4 & $\ldots$ & $\ldots$ & $\ldots$ & $\ldots$ & $\ldots$ & $\ldots$ \\
\hline Other assets & 4.4 & 4.1 & 3.0 & 2.9 & $\ldots$ & $\ldots$ & $\ldots$ & $\ldots$ & $\ldots$ & $\ldots$ \\
\hline Financial liabilities & 68.4 & 70.9 & 69.4 & 65.6 & $\ldots$ & $\ldots$ & $\ldots$ & $\ldots$ & $\ldots$ & $\ldots$ \\
\hline Currency and deposits & 0.2 & 0.3 & 0.3 & 0.3 & $\ldots$ & $\ldots$ & $\ldots$ & $\ldots$ & $\ldots$ & $\ldots$ \\
\hline Securities other than shares & 47.4 & 50.2 & 49.6 & 47.5 & $\ldots$ & $\ldots$ & $\ldots$ & $\ldots$ & $\ldots$ & $\ldots$ \\
\hline Loans & 20.6 & 20.3 & 19.4 & 17.6 & $\ldots$ & $\ldots$ & $\ldots$ & $\ldots$ & $\ldots$ & $\ldots$ \\
\hline Other liabilities & 0.2 & 0.2 & 0.2 & 0.1 & $\ldots$ & $\ldots$ & $\ldots$ & $\ldots$ & $\ldots$ & $\ldots$ \\
\hline Transactions, net & -3.8 & -3.4 & -1.6 & 0.0 & $\ldots$ & $\cdots$ & $\cdots$ & $\cdots$ & $\cdots$ & $\cdots$ \\
\hline Financial assets & -0.5 & -0.2 & 0.5 & 0.4 & $\ldots$ & $\ldots$ & $\ldots$ & $\ldots$ & $\ldots$ & $\ldots$ \\
\hline Financial liabilities & 3.2 & 3.1 & 2.1 & 0.4 & $\ldots$ & $\cdots$ & $\cdots$ & $\cdots$ & $\ldots$ & $\ldots$ \\
\hline Other economic flows, net & -0.9 & 0.3 & 1.6 & 1.5 & $\ldots$ & $\ldots$ & $\ldots$ & $\ldots$ & $\ldots$ & $\ldots$ \\
\hline Financial assets & 0.3 & 0.6 & 0.3 & 0.2 & $\ldots$ & $\ldots$ & $\ldots$ & $\ldots$ & $\ldots$ & $\ldots$ \\
\hline Financial liabilities & 1.2 & 0.3 & -1.3 & -1.3 & $\ldots$ & $\ldots$ & $\ldots$ & $\ldots$ & $\ldots$ & $\ldots$ \\
\hline
\end{tabular}

Source: Ministry of Finance, Bundesbank, Federal Statistical Office. 
Table 7. Expenditures under the Authorities' Stimulus Packages, October and November, 2008 (in millions of euros; unless otherwise specified)

\begin{tabular}{|c|c|c|}
\hline & 2009 & 2010 \\
\hline \multicolumn{3}{|l|}{ October package } \\
\hline $\begin{array}{l}\text { Increased health insurance contribution from } 14.9 \text { percent to } 15.5 \text { percent } \\
\text { of gross wages--tax on employers' portion }\end{array}$ & 265 & 530 \\
\hline Personal income tax deductibility of 20 percent of cost of household help & & 80 \\
\hline Personal income tax deductibility of health care contributions & & 7820 \\
\hline $\begin{array}{l}\text { Increased child benefit by Euro } 10 \text { (Euro } 16 \text { for third child and more) and } \\
\text { child tax deduction to Euro } 6000 \text { from Euro } 5808\end{array}$ & 2275 & 2145 \\
\hline $\begin{array}{l}\text { School start benefit of Euro } 100 \text { for first graders of parents who are social } \\
\text { assistance recipients }\end{array}$ & 140 & 140 \\
\hline Reduction in unemployment contribution from 3.3 to 2.8 percent & 4000 & 3200 \\
\hline \multicolumn{3}{|l|}{ November package } \\
\hline Transport investment (water, rail, road) & 1000 & 1000 \\
\hline Income tax deductibility of handimen services & & 900 \\
\hline Subsidy for energy-efficient building (expansion of existing KfW program) & 42 & 220 \\
\hline Other KfW-programs incl. regional lending for investment purposes & 73 & 76 \\
\hline Degressive depreciation of 25 percent of investment in immovables & 1940 & 4325 \\
\hline Temporary suspension of car excise tax to end-June 2009 & 380 & 135 \\
\hline Temporary special depreciation of capital market investment & 235 & 370 \\
\hline $\begin{array}{l}\text { Increased funds for Joint Taskforce for Improvement of Regional Economic } \\
\text { Structure }\end{array}$ & 200 & 100 \\
\hline Extension of short-term labor benefit from 12 to 18 months & 300 & 300 \\
\hline \multicolumn{3}{|l|}{ Contractionary measures (October 2008 package) } \\
\hline $\begin{array}{l}\text { Reduction in unemployment contribution from } 3.3 \text { to } 2.8 \text { percent of gross } \\
\text { wages--tax on employers' portion }\end{array}$ & -65 & -210 \\
\hline $\begin{array}{l}\text { Increased health insurance contribution from } 14.9 \text { percent to } 15.5 \text { percent } \\
\text { of gross wages }\end{array}$ & -6000 & -6000 \\
\hline Net fiscal stimulus & 4785 & 14831 \\
\hline (in percent of GDP) & 0.2 & 0.6 \\
\hline
\end{tabular}




\section{ANNEX I. Germany: Fund Relations}

(As of November 30, 2008)

- Mission: November 12 to 24, 2008 in Frankfurt, Bonn, and Berlin. The concluding statement of the mission is available at http://www.imf.org/external/np/ms/2008/112408.htm.

- $\quad$ Staff team: Mr. Mody (Head), Mmes. Carare, and Ohnsorge, (EUR) and Messrs. Seelig and Jobst (MCM), Mr. Stehn (FAD), and Ms. Luedersen (LEG).

- Country interlocutors: The Bundesbank President Weber, Federal Financial Supervisory Authority (BaFin) President Sanio, State Secretaries Asmussen (Finance), and Pfaffenbach (Economy), members of the German Council of Economic Experts, and senior representatives at the Chancellery, several ministries, the Bundesbank, and BaFin. Mr. von Stenglin, the Alternate Executive Director for Germany, also participated in the discussions. Meetings took place with parliamentarians, Länder representatives, labor unions, employers, research institutes, and financial market participants.

- $\quad$ Fund relations: The previous Article IV consultation took place on February 22, 2008. The associated Executive Board's assessment and staff report are available at http://www.imf.org/external/pubs/cat/longres.cfm?sk=21759.0.

I. Membership Status: Joined August 14, 1952.

II. General Resources Account:

Quota

Fund holdings of currency

Reserve position in Fund

III. SDR Department:

Net cumulative allocation

Holdings

IV. Outstanding Purchases and Loans:

V. Financial Arrangements:
SDR Million

$13,008.20$

$11,461.65$

$1,546.61$

SDR Million

$1,210.76$

100.00

$1,426.90$

None

None

VI. Projected Payments to Fund:

(SDR Million; based on existing use of resources and present holdings of SDRs): 
Principal

Charges/Interest

Total
Forthcoming

\begin{tabular}{rrrrr}
\hline 2008 & 2009 & 2010 & 2011 & 2012 \\
\hline-- & -- & -- & -- & -- \\
-- & 0.09 & 0.09 & 0.09 & 0.09 \\
\hline 0.09 & 0.09 & 0.09 & 0.09 & 0.09
\end{tabular}

\section{Exchange Rate Arrangement:}

Germany's currency is the euro, which floats freely and independently against other currencies.

Germany is an Article VIII member and maintains an exchange system free of restrictions on payments and transfers for current international transactions. It maintains measures adopted for security reasons, which have been notified to the Fund for approval in accordance with the procedures of Decision 144 and does so solely for the preservation of national or international security.

\section{Anti-Money Laundering/Combating the Financing of Terrorism (AML/CFT)}

The authorities have moved towards a more risk-based approach, in which the intensity of audits and inspections should reflect institutions' AML/CFT risk. A dialogue with the associations of certified public accountants and other auditors has led to a revised AML/CFT assessment methodology in 2005. Legal revisions also granted the BaFin the power to freeze funds without a court order or other involvement of prosecution authorities if facts suggest that funds serve the purpose of terrorist financing. BaFin can now also require financial holding groups and financial conglomerates to develop a coordinated risk management approach for the whole group. An assessment under the international standard for AML/CFT will be conducted by the Fund's Legal Department in May 2009. The assessment will address, amongst other matters, improvements of AML/CFT laws concerning non-bank financial institutions and concerns surrounding remittance flows either through or from Germany to allegedly fund terrorist activity.

\section{Staff Analytical Work on Germany, 2003-08}

\section{Growth and Competitiveness}

- Growth Linkages within Europe, IMF Country Report No. 08/81.

- Economic Impact of Shortages of Skilled Labor in Germany, IMF Country Report No. $08 / 81$.

- What explains Germany’s Rebounding Export Market Share? CESifo Working Paper No. 1957.

- $\quad$ Long-run Growth in Germany. IMF Country Report No. 06/17.

- Does Excessive Regulation Impede Growth in Germany? IMF Country Report No. 06/17. 
- The Performance of Germany's Non-Financial Corporate Sector - An International Perspective. IMF Country Report No. 06/17.

- Investment Trends in OECD Countries: Long-Term Developments and Future Prospects. IMF Country Report No. 04/340.

- Does PPP hold in the Long Run? Germany and Switzerland. IMF Country Report No. 04/340.

- Business Investment in the Current Cycle. IMF Country Report No. 03/342.

\section{Inflation}

- Inflation Smoothing and the Modest Effect of VAT in Germany, IMF Working Paper No. 08/175.

\section{Fiscal Policy and Entitlement Programs}

- Tax Reform and Debt Sustainability in Germany: An Assessment Using the Global Fiscal Model. IMF Country Report No. 06/436.

- Business Tax Reform. IMF Country Report No. 06/436.

- Why is Germany's Deficit so Large?, IMF Country Report No. 06/17.

- A Preliminary Public Sector Balance Sheet for Germany, IMF Country Report No. 06/17.

- Germany: A Long-Run Fiscal Scenario Based on Current Policies, IMF Country Report No. 06/17.

- Pensions and Growth. IMF Country Report No. 04/340.

- Federalism and the Political Economy of Adjustment. IMF Country Report No. $04 / 340$.

\section{Labor Markets}

- The Employment Effects of Labor and Product Markets Deregulation and their Implications for Structural Reform. CESifo Working Paper No 1709, May 2006.

- Employment, Unemployment, and Labor Supply in Germany. IMF Country Report No. 04/340.

- The Unbearable Stability of the German Wage Structure: Evidence and Interpretation. IMF Staff Papers, August 2004.

\section{The Financial System}

- Landesbanken: A Measure of the Costs for Taxpayers. IMF Country Report No. 06/436.

- The German Banking Sector: Credit Decline, Soundness and Efficiency. IMF Country Report No. 06/17.

- Germany's Three-Pillar Banking System. IMF Occasional Paper 233 (2004).

- Germany's Financial System: International Linkages and the Transmission of Financial Shocks. IMF Country Report No. 03/342.

\section{Corporate Governance}

- Germany's Corporate Governance Reforms: Has the System Become Flexible Enough?, IMF Working Paper No. 08/179. 


\section{ANNEX II. Germany: Statistical Issues}

Data provision is adequate for surveillance. Germany has a full range of statistical publications and subscribes to the Fund's Special Data Dissemination Standard (SDDS). A ROSC Data Module report was published in January 2006. The authorities make substantial use of the Internet to facilitate on-line access to data and press information.

Germany adopted the European System of Integrated Economic Accounts 1995 (ESA95) in 1999. The 2005 ROSC Data Module mission found that the macroeconomic statistics generally follow internationally accepted standards and guidelines on concepts and definitions, scope, classification and sectorization, and basis for recording. However, the sources for estimating value added for a few categories of service industries could be improved. A direct source for quarterly changes in inventories, which is an important contributor to short-term deviation in the trend GDP growth rate, is lacking. There is no systematic, proactive process to monitor the ongoing representativeness of the samples of local units and products between rebases of the producer price index.

Comprehensive data reporting systems support the accuracy and reliability of the government finance and balance of payments statistics. However, although explanatory documentation exists, differences between the general government data in the ESA95 classification and the general government cash data on an administrative basis is impairing fiscal analysis; Germany publishes - through Eurostat - general government revenue, expenditure, and balance on an accrual basis on a quarterly basis (ESA95) and submits annual data for publication in the Government Financial Statistics Yearbook, in GFSM 2001 format. Monthly data are only disseminated on a cash-basis.

Germany is participating in the Coordinated Compilation Exercise for financial soundness indicators (FSIs). In 2006, as part of this exercise, the German authorities compiled a comprehensive set of FSI data and metadata. 


\begin{tabular}{|c|c|c|c|c|c|c|c|}
\hline \multicolumn{8}{|c|}{$\begin{array}{l}\text { Germany: Table of Common Indicators Requir } \\
\text { (As of December 9, 2008) }\end{array}$} \\
\hline & \multirow{2}{*}{$\begin{array}{l}\text { Date of latest } \\
\text { observation }\end{array}$} & \multirow{2}{*}{$\begin{array}{l}\text { Date } \\
\text { received }\end{array}$} & \multirow{2}{*}{$\begin{array}{l}\text { Frequency } \\
\text { of } \\
\text { Data }^{7}\end{array}$} & \multirow{2}{*}{$\begin{array}{l}\begin{array}{c}\text { Frequency } \\
\text { of } \\
\text { Reporting }\end{array}\end{array}$} & \multirow{2}{*}{$\begin{array}{l}\text { Frequency of } \\
\text { Publication }^{7}\end{array}$} & \multicolumn{2}{|c|}{ Memo Items } \\
\hline & & & & & & $\begin{array}{l}\text { Data Quality- } \\
\text { Methodological } \\
\text { soundness }{ }^{8}\end{array}$ & $\begin{array}{l}\text { Data Quality- } \\
\text { Accuracy and } \\
\text { reliability }^{9}\end{array}$ \\
\hline Exchange Rates & December 08 & $12 / 2 / 2008$ & $\mathrm{D}$ & $\mathrm{D}$ & $\mathrm{D}$ & & \\
\hline $\begin{array}{l}\text { International Reserve Assets and } \\
\text { Reserve Liabilities of the Monetary } \\
\text { Authorities }^{1}\end{array}$ & October 08 & November 08 & $M$ & $M$ & $\mathrm{M}$ & & \\
\hline Reserve/Base Money & October 08 & November 08 & $\mathrm{M}$ & $M$ & $\mathrm{M}$ & & \\
\hline Broad Money & October 08 & November 08 & $\mathrm{M}$ & $\mathrm{M}$ & $\mathrm{M}$ & & \\
\hline Central Bank Balance Sheet & October 08 & November 08 & M & M & M & & \\
\hline $\begin{array}{l}\text { Consolidated Balance Sheet of the } \\
\text { Banking System }\end{array}$ & October 08 & November 08 & $\mathrm{M}$ & $M$ & $\mathrm{M}$ & & \\
\hline Interest Rates & November 08 & December 08 & $\mathrm{M}$ & M & M & & \\
\hline Consumer Price Index & October 08 & November 08 & $\mathrm{M}$ & M & M & & \\
\hline $\begin{array}{l}\text { Revenue, Expenditure, Balance } \\
\text { and Composition of Financing }{ }^{3}- \\
\text { General Government }^{4}\end{array}$ & June 08 & November 08 & $\bar{Q}$ & $\mathrm{Q}$ & $\bar{Q}$ & 0 & \\
\hline $\begin{array}{l}\text { Revenue, Expenditure, Balance } \\
\text { and Composition of Financing }{ }^{3}- \\
\text { Central Government }\end{array}$ & October 08 & November 08 & $Q$ & $\mathrm{Q}$ & $Q$ & $\mathrm{LU}, \mathrm{LU}, \mathrm{LU}, \mathrm{U}$ & $U, U, U, U, U$ \\
\hline $\begin{array}{l}\text { Stocks of Central Government and } \\
\text { Central Government-Guaranteed } \\
\text { Debt }^{5}\end{array}$ & September 08 & November 08 & Q & Q & Q & & \\
\hline
\end{tabular}




\begin{tabular}{|c|c|c|c|c|c|c|c|}
\hline \multicolumn{8}{|c|}{$\begin{array}{l}\text { Germany: Table of Common Indicators Required for Surveillance } \\
\text { (As of December 9, 2008) }\end{array}$} \\
\hline External Current Account Balance & September 08 & November 08 & $\mathrm{M}$ & $\mathrm{M}$ & $\mathrm{M}$ & \multirow{2}{*}{$\mathrm{O}, \mathrm{O}, \mathrm{LO}, \mathrm{O}$} & \multirow{2}{*}{$\mathrm{O}, \mathrm{O}, \mathrm{O}, \mathrm{O}, \mathrm{O}$} \\
\hline $\begin{array}{l}\text { Exports and Imports of Goods and } \\
\text { Services }\end{array}$ & September 08 & November 08 & $\mathrm{M}$ & $\mathrm{M}$ & $\mathrm{M}$ & & \\
\hline GDP/GNP & Q3 08 & November 08 & $\mathrm{Q}$ & Q & $Q$ & $\mathrm{O}, \mathrm{O}, \mathrm{O}, \mathrm{O}$ & $\mathrm{LO}, \mathrm{O}, \mathrm{O}, \mathrm{O}, \mathrm{O}$ \\
\hline Gross External Debt & $\mathrm{H} 108$ & November 08 & $\begin{array}{l}\text { Semi- } \\
\text { annual }\end{array}$ & $\begin{array}{l}\text { Semi- } \\
\text { annual }\end{array}$ & Semi-annual & & \\
\hline International Investment Position ${ }^{6}$ & Q1 08 & July 08 & & & & & \\
\hline \multicolumn{8}{|c|}{$\begin{array}{l}1 \text { Includes reserve assets pledged or otherwise encumbered as well as net derivative positions. } \\
{ }^{2} \text { Both market-based and officially-determined, including discount rates, money market rates, rates on treasury bills, notes, and bonds. } \\
{ }^{3} \text { Foreign, domestic bank, and domestic nonbank financing. } \\
{ }^{4} \text { The general government consists of the central government (budgetary funds, extra budgetary funds, and social security funds) and state and local governments. } \\
{ }^{5} \text { Including currency and maturity composition } \\
{ }^{6} \text { Includes external gross financial asset and liability positions vis-a vis nonresidents. } \\
{ }^{7} \text { Daily (D); weekly (W); monthly (M); quarterly (Q); annually (A); irregular (I); and not available (NA) } \\
\left.{ }^{8} \text { Reflects the assessment provided in the data ROSC (published on January 18, 2006, and based on the findings of the mission that took place during July } 5-20,2005\right) \text { for } \\
\text { the dataset corresponding to the variable in each row. The assessment indicates whether international standards concerning concepts and definitions, scope, } \\
\text { classification/sectorization, and basis for recording are fully observed (O); largely observed (LO); largely not observed (LNO); not observed (NO); and not available (NA). } \\
{ }_{9}^{9} \text { Same as footnote 9, except referring to international standards concerning (respectively) source data, assessment of source data, statistical techniques, assessment and } \\
{ }^{v} \text { alidation of intermediate data and statistical outputs, and revision studies. }\end{array}$} \\
\hline
\end{tabular}


INTERNATIONAL MONETARY FUND

\begin{abstract}
GERMANY
Staff Report for the 2008 Article IV Consultation Supplementary Information
\end{abstract}

Prepared by the European Department

Approved by Marek Belka and Tamim Bayoumi

January 13, 2009

This supplement provides information on economic developments since the staff report was issued. The new information does not alter the thrust of the staff appraisal.

\title{
1. Plummeting sentiments and orders have required a large downward revision in
} GDP growth projections, especially for 2009. A much worse than anticipated fourth quarter is estimated to bring growth in 2008 down to 1.3 percent, as against the WEO November 2008 and staff report projection of 1.7 percent (Text Table). But along with the sharp downturn in global consensus forecasts, the growth projection for Germany in 2009 has been marked down to $-2 \frac{1}{2}$ percent from $-3 / 4$ percent.

\begin{tabular}{|c|c|c|c|c|}
\hline \multicolumn{5}{|c|}{ Real GDP Growth Developments and Projections 1/ } \\
\hline & 2007 & 2008 & 2009 & 2010 \\
\hline Real GDP growth & 2.5 & 1.3 & -2.5 & 0.1 \\
\hline $\begin{array}{l}\text { Revisions from November } 2008 \\
\text { WEO and Staff Report }\end{array}$ & $\ldots$ & -0.4 & -1.7 & -0.4 \\
\hline Q4 on Q4 growth 1/ & 1.7 & -1.2 & -1.0 & 0.4 \\
\hline
\end{tabular}

\section{These revisions reflect an extraordinary drop in world trade and a sharp rise in} corporate stress. German exports are decelerating rapidly along with world trade. Corporate stress is reflected in increasing bankruptcies and in corporate bond spreads, which shot up after the failure of Lehman Brothers and have remained high despite easing in the credit and money markets. Weakening world trade and corporate stress are feeding on each other worldwide: Germany, with its high dependence on exports, is caught in that spiral. Domestic consumption and investment can be expected to remain weak. The fiscal stimulus (including the likely addition) will help prevent a further weakening of domestic demand, absent which the 2009 outcome would have been dire.

3. Recovery in $\mathbf{2 0 1 0}$ is likely to be slow. Assuming that the fiscal stimulus plans - in Germany and also in the United States and China - remain on schedule, they will help the recovery. However, with the continued weakness in corporate balance sheets, the global 
investment cycle is unlikely to resume with sufficient vigor for German exporters to see a strong renewal in orders and for consumers to feel confident about their employment and income prospects.

Business assessments, especially expectations have steadily declined.

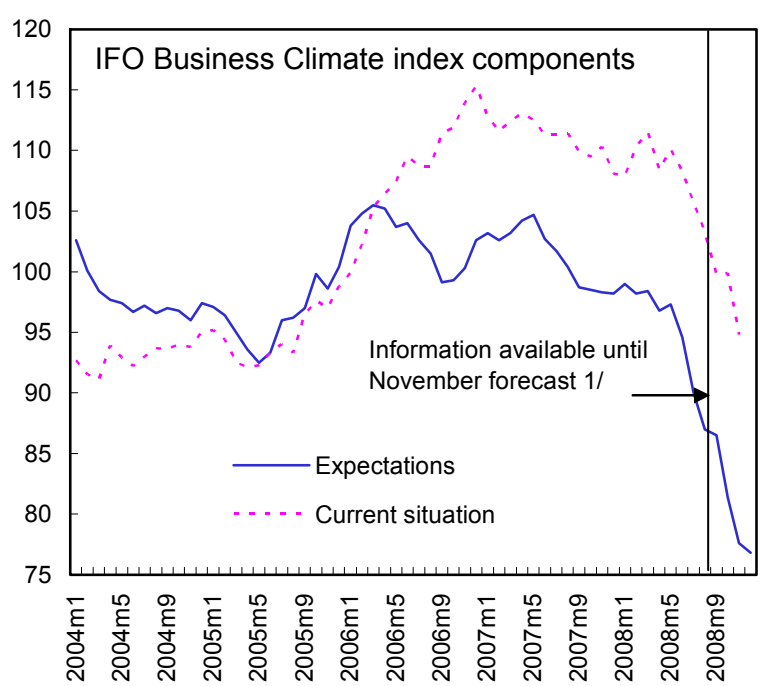

German exports are set to contract along with world trade.

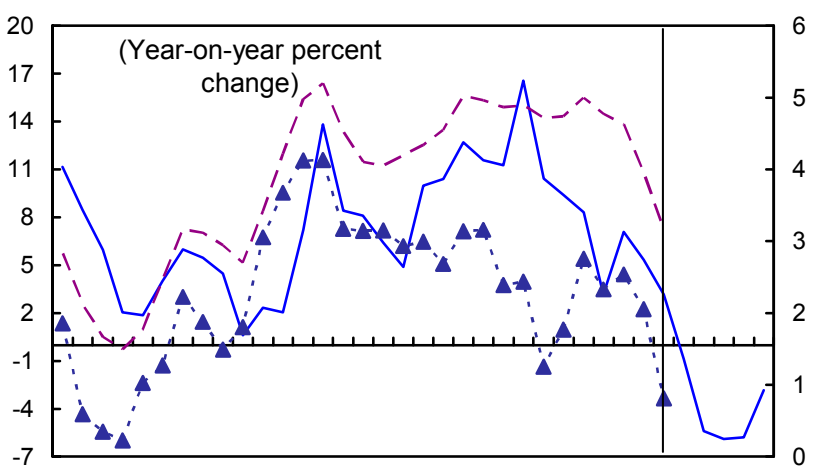

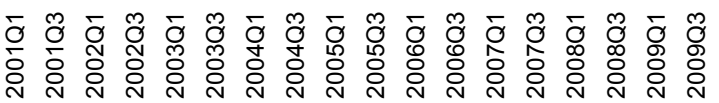

- Real exports growth (left scale)

- - - World real GDP growth (right scale, November 2008 WEO)

- - - - US real GDP growth (right scale, November 2008 WEO)
Global consensus forecasts for 2009 have been sharply lowered.

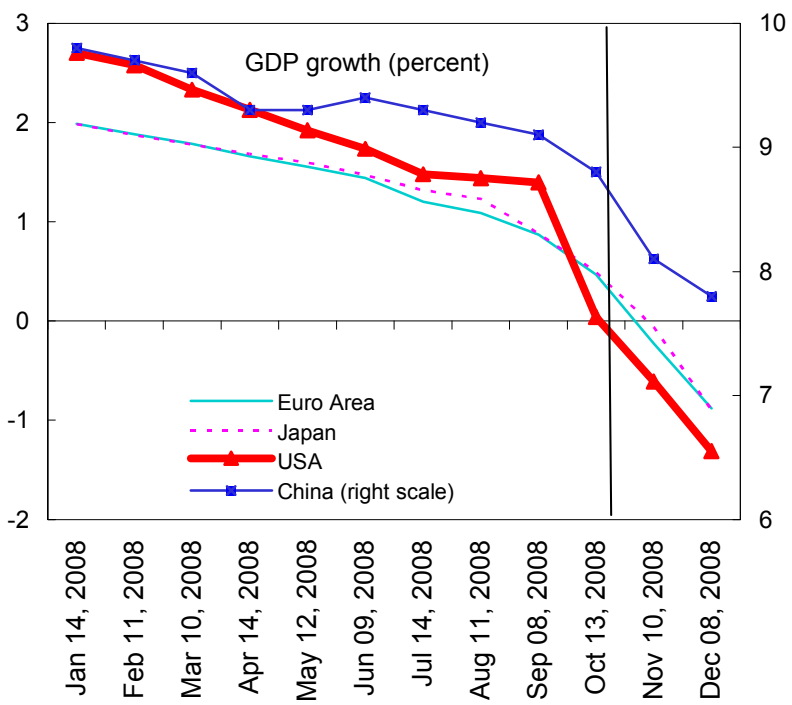

Corporate bond spreads are consistent with prolonged weakness.

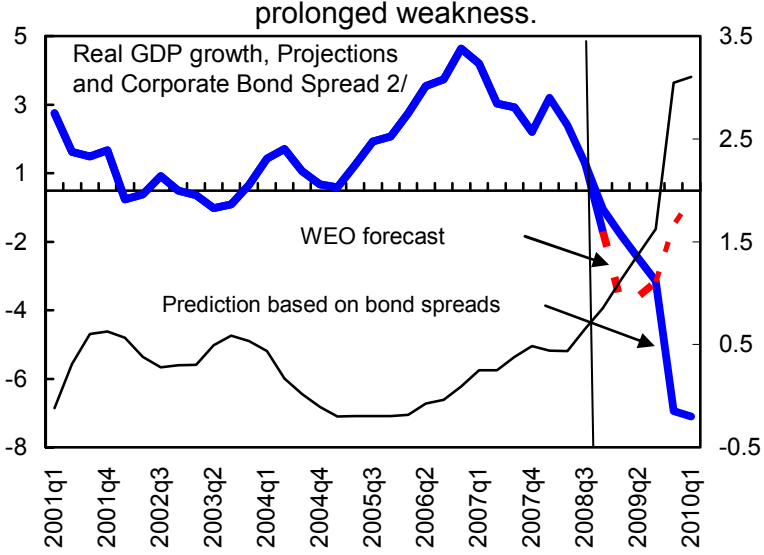

Real GDP growth and projections (left scale; blue - projection from corporate spread, red dotted - WEO projection)

— Corporate bond spread (brought forward 1 year, right scale)

Source: Bundesbank, IFO, Federal Statistical Office, World Economic Outlook, JPMorgan, Consensus Forecast.

1/ For all charts vertical line indicates information available until the calculation of the November forecast. 2/ Real GDP Growth and Projections (year-on-year in percent, left scale) and Corporate Bond Spread (quarterly average, in percentage points, right scale) . 
4. The authorities have announced a significant increase in the fiscal stimulus. Under a new package, as widely reported in the press, 50 billion euros are expected to be spent over two years. The additional 0.9 percent of GDP envisaged for 2009 will bring the total stimulus for this year to $1 \frac{1 / 4}{4}$ of GDP (Text Table). The Staff Report had recommended a stimulus of $1 \frac{1}{2}$ to 2 percent of GDP: but with the dramatic and continuing deterioration in economic prospects, a boost of at least 2 percent of GDP would have been desirable. The reduction in social security contributions is in

\begin{tabular}{lrr}
\multicolumn{3}{c}{$\begin{array}{c}\text { Increase in General Government Deficit } \\
\text { Due to Legislative Measures } \\
\text { (in percent of GDP) }\end{array}$} \\
\hline \multicolumn{2}{c}{2009} & 2010 \\
\hline October and November packages & 0.2 & 0.4 \\
Commuter subsidy & 0.3 & 0.0 \\
January package* & 0.9 & 0.2 \\
Total & 1.3 & 0.6 \\
\hline${ }^{*}$ Assumptions based on news reports. &
\end{tabular}
line with the recommendation of the Staff Report, as is the step up in public infrastructure spending. The commuter subsidy and the cut in personal income tax rates are likely to be less effective, in staff's view. The total stimulus in 2010 will amount to 0.6 percent of GDP.

\section{Support by Soffin has provided stability to the financial system, but further} asset quality deterioration will imply continued need for such support. CDS spreads of financial institutions are off their post-Lehman peaks. Bank lending has remained in positive territory. Guarantees issued by Soffin will facilitate rollover of banks' funding. But funding conditions remain tight, as reflected in the Deutsche Bank decision to pay the penalty required to extend a maturing obligation. Moreover, with deterioration in bank asset quality, capital needs are likely to rise. Commerzbank recently required a second capital injection. In this regard, regular financial reporting of FMSF transactions, including their approval status by the European Commission, would provide transparency and bolster confidence. Finally, the continuing need for support to Landesbanken remains a concern. The burden of this support has appropriately fallen on the states, but the implication is that rationalization of these financial institutions should be high priority.
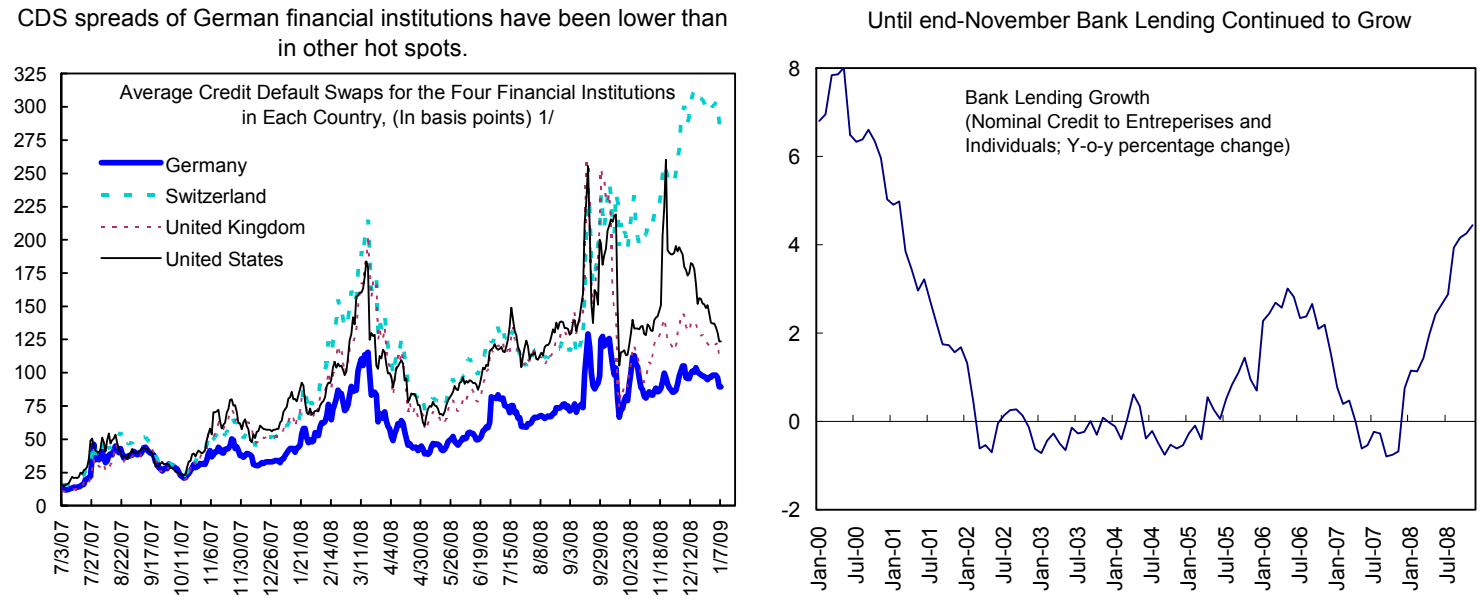

Source: Bloomberg, and IMF Staff calculations.

1/ Four largest financial institutions for each country are as follows: Germany Deutsche Bank, Commerzbank AG, Munich Reinsurance, and Bayerische Hypo \& Vereinsbank AG. Switzerland - Credit Suisse, Swiss Reinsurance, UBS AG, and Zurich Allied AG. United Kingdom - HBOS, Barclays Bank, HSBC Bank, and Royal Bank of Scotland. United States - Citigroup, Bank of America, JP Morgan Chase, and Wells Fargo \& Co.
Until end-November Bank Lending Continued to Grow 
GERMANY

Selected Economic and Social Indicators

\begin{tabular}{|c|c|c|c|c|c|c|c|c|c|}
\hline & 2002 & 2003 & 2004 & 2005 & 2006 & 2007 & $20081 /$ & $20091 /$ & $20101 /$ \\
\hline \multicolumn{10}{|l|}{ Real economy (change in percent) } \\
\hline Real GDP & 0.0 & -0.2 & 1.2 & 0.8 & 3.0 & 2.5 & 1.3 & -2.5 & 0.1 \\
\hline Total domestic demand & -2.0 & 0.6 & -0.1 & 0.0 & 2.1 & 1.1 & 1.6 & -0.1 & 0.2 \\
\hline $\mathrm{CPI}$ (average) & 1.4 & 1.0 & 1.8 & 1.9 & 1.8 & 2.3 & 2.8 & 0.2 & 0.1 \\
\hline Standardized unemployment rate (in percent) & 7.7 & 8.8 & 9.2 & 10.6 & 9.8 & 8.4 & 7.3 & 8.5 & 9.1 \\
\hline Employment growth & -0.6 & -0.9 & 0.4 & -0.1 & 0.7 & 1.7 & 1.5 & -0.2 & -0.7 \\
\hline Gross national saving (percent of GDP) & 20.3 & 19.9 & 22.2 & 22.6 & 24.3 & 26.3 & 25.2 & 23.6 & 23.5 \\
\hline Gross domestic investment (percent of GDP) & 18.3 & 17.9 & 17.5 & 17.4 & 18.2 & 18.7 & 19.2 & 20.4 & 19.8 \\
\hline \multicolumn{10}{|l|}{ Public finance (percent of GDP) } \\
\hline General government balance & -3.7 & -4.0 & -3.8 & -3.3 & -1.5 & -0.2 & -0.1 & -3.3 & -4.6 \\
\hline General government structural balance & -2.9 & -3.2 & -2.8 & -2.3 & -1.2 & -0.3 & -0.3 & -2.1 & -2.7 \\
\hline General government debt & 59.6 & 62.8 & 64.7 & 66.4 & 66.0 & 65.0 & 68.7 & 76.1 & 80.1 \\
\hline \multicolumn{10}{|l|}{ Money and credit (end of year, percent change) 2/ } \\
\hline Credit to private sector & 0.9 & 0.0 & -0.2 & 2.2 & 3.5 & 3.2 & 6.6 & $\ldots$ & $\ldots$ \\
\hline M3 & $\ldots$ & 3.5 & 2.2 & 5.2 & 4.9 & 10.6 & 11.1 & $\ldots$ & $\ldots$ \\
\hline \multicolumn{10}{|l|}{ Interest rates (percent) } \\
\hline Money market rate $3 /$ & 3.3 & 2.3 & 2.1 & 2.1 & 3.7 & 4.8 & 3.4 & $\ldots$ & $\ldots$ \\
\hline Government bond yield 3 / & 4.8 & 4.1 & 4.1 & 3.6 & 3.8 & 4.3 & 3.2 & $\ldots$ & $\ldots$ \\
\hline \multicolumn{10}{|l|}{ Balance of payments (percent of GDP) } \\
\hline Current account balance & 2.0 & 2.0 & 4.7 & 5.2 & 6.1 & 7.6 & 6.0 & 3.3 & 3.8 \\
\hline Trade balance & 5.8 & 5.5 & 6.3 & 6.4 & 6.3 & 7.8 & 7.1 & 5.0 & 5.5 \\
\hline Exports & 30.2 & 30.5 & 33.0 & 35.2 & 38.9 & 40.7 & 41.5 & 40.2 & 41.3 \\
\hline volume (annual percent change) & 3.5 & 3.1 & 10.6 & 7.6 & 12.7 & 7.7 & 3.9 & -4.9 & 2.7 \\
\hline Imports & 24.4 & 25.1 & 26.7 & 28.8 & 32.6 & 32.9 & 34.5 & 35.2 & 35.9 \\
\hline volume (annual percent change) & -0.3 & 6.7 & 8.6 & 6.8 & 13.5 & 5.1 & 5.2 & 1.5 & 3.2 \\
\hline Net oil imports (billions of US\$) & 27.9 & 37.0 & 42.5 & 61.4 & 78.8 & 79.8 & 111.1 & 57.3 & 68.7 \\
\hline FDI balance & 1.7 & 1.1 & -1.1 & -1.0 & -1.4 & -3.5 & -2.3 & -1.3 & -1.0 \\
\hline Official reserves minus gold (billions of US $\$$ ) 4/ & 51.2 & 50.7 & 48.8 & 45.1 & 41.7 & 44.3 & 43.9 & $\ldots$ & $\ldots$ \\
\hline \multicolumn{10}{|l|}{ Exchange rate } \\
\hline Exchange rate regime & \multicolumn{9}{|c|}{ Participant in euro zone } \\
\hline Present rate (January 12, 2009) & \multicolumn{9}{|c|}{ Euro 0.7 per US\$ } \\
\hline Nominal effective rate $(2000=100) 3 /$ & 102.5 & 108.4 & 110.5 & 110.3 & 112.3 & 115.9 & 115.8 & $\ldots$ & $\ldots$ \\
\hline Real effective rate $(2000=100) 5 /$ & 101.4 & 105.9 & 105.5 & 102.2 & 98.6 & 98.0 & 95.1 & $\ldots$ & $\ldots$ \\
\hline
\end{tabular}

Sources: Deutsche Bundesbank; IMF, International Financial Statistics; IMF, World Economic Outlook; Eurostat; and staff projections.

$1 /$ Staff estimates and projections, if not otherwise indicated.

2/ Reflects Germany's contribution to M3 of the euro area. Data not shown for 2002 due to a series break. Data for 2008 refers to November.

3/ Data for 2008 refers to December

4/ Data for 2008 refers to November.

5/ Based on relative normalized unit labor cost in manufacturing. Data for 2008 refers to December.

$6 /$ At risk of poverty rate: cut-off point: $60 \%$ of median equivalised income after social transfers. 


\section{INTERNATIONAL MONETARY FUND}

Public Information Notice (PIN) No. 09/05

FOR IMMEDIATE RELEASE

January 22, 2009
International Monetary Fund

$70019^{\text {th }}$ Street, NW

Washington, D. C. 20431 USA

\section{IMF Executive Board Concludes 2008 Article IV Consultation with Germany}

On January 14, 2009, the Executive Board of the International Monetary Fund (IMF) concluded the Article IV consultation with Germany. ${ }^{1}$

\section{Background}

After robust growth in 2006 and 2007, real GDP slowed in 2008 and is now set to decline sharply. World demand is decelerating and confidence indicators are deteriorating. Financial market stress has spilled over into sentiment and the real economy. The German consumer's conservatism under the current uncertain conditions will amplify the export slowdown and investment decisions are likely to be postponed. In 2008, GDP is projected to grow at 1.3 percent. An economic contraction of $2 \frac{1}{2}$ percent is projected for 2009 , followed by a slow recovery in 2010 . The risks remain tilted to the downside.

The financial market turbulence has exposed vulnerabilities in the German financial system. Already in summer 2007, the failure of IKB and Sachsen LB required government intervention. In the aftermath of the failure of Lehman Brothers in Fall 2008, confidence in the system was again threatened by the liquidity rollover requirements at Hypo Real Estate. A public commitment to protect household deposits provided initial stability. This was followed by a comprehensive package in mid-October 2008 to support market liquidity and bank capitalization as part of a globally-coordinated effort.

\footnotetext{
${ }^{1}$ Under Article IV of the IMF's Articles of Agreement, the IMF holds bilateral discussions with members, usually every year. A staff team visits the country, collects economic and financial information, and discusses with officials the country's economic developments and policies. On return to headquarters, the staff prepares a report, which forms the basis for discussion by the Executive Board. At the conclusion of the discussion, the Managing Director, as Chairman of the Board, summarizes the views of Executive Directors, and this summary is transmitted to the country's authorities.
} 
Fiscal consolidation in recent years along with growth in incomes and employment during 2007 supported a balanced budget in 2008. In 2009 and 2010, however, the deficit is expected to widen with a weakening economy and labor market. The authorities' stimulus package is expected to provide a needed impulse to domestic demand, but will also increase the deficit. To address concerns with regard to long-term fiscal sustainability, the authorities aim to introduce a deficit rule that would constrain the structural fiscal balance to about zero. But more ambitious plans for fiscal federalism reform have been postponed until 2019.

\section{Executive Board Assessment}

Executive Directors noted that, in the past three months, Germany has come under heightened pressure from the global economic and financial turmoil, reflecting the economy's high degree of openness and integration with the world economy. With the sharp drop in world trade and continuing weakness in domestic demand, Germany faces the prospect of a sizeable, and possibly extended, economic downturn. Corporate and financial sector stresses in the German economy - thus far relatively dissociated from each other-risk becoming more intertwined in the period ahead. Against this background, Directors welcomed the recent initiatives by the German authorities to strengthen significantly the financial safety net and to give valuable economic stimulus. They recognized that the fundamentals of the German economy remain strong, and applauded the sustained fiscal prudence of the last few years that has created the needed room for a sizeable fiscal boost to the economy.

Directors welcomed the German authorities' continuing priority to maintaining financial stability and stabilizing the real economy. Global policy actions and measures to contain the risk of a costly global self-reinforcing slump should preferably be coordinated regionally and internationally for maximum effect. Germany has a special leadership role to play in this process, given the size of its economy and the substantial spillovers into and from Germany.

Directors noted that the global financial crisis has highlighted important vulnerabilities of the German financial system, which could be intensified by the economic slowdown in Germany. They welcomed the authorities' decisive response, noting in particular the creation of the Financial Market Stabilization Fund (FMSF) as vital to shielding the financial sector. A number of guarantees have been issued, which will help banks meet their short-term funding needs. Directors also welcomed the efforts to buttress capital positions. Given the low level of capital in several banks, further recapitalization may be desirable in view of expected asset quality deterioration. Directors also recommended that the agency administering the FMSF use its authority more broadly for enhancing the soundness of the financial sector. In particular, Directors called for a proactive restructuring and downsizing of the Landesbanken, which are a continuing drain on public finances and a threat to financial stability.

Directors called for strengthened deposit insurance, a critical element of the financial safety net, given the risks associated with the existing multiple protection schemes that have typically relied on ex post burden-sharing. A base layer of mandatory deposit insurance-ex ante funded by contributions from all banks-would provide unified terms 
of protection for depositors and reduce incentives to shift deposits among the existing schemes. The evolving European Union rules should provide guidance on coverage limits.

Directors observed that the case for a tighter bank regulatory and supervisory process has become more compelling. To respond promptly to problem situations, the authorities were encouraged to place greater reliance on timely supervisory assessments independently of the banks' annual external audit cycle, and to link prudential regulation and supervision to a system of macro-surveillance and stability analysis. In this context, greater consolidation of regulatory and supervisory resources could yield significant benefits.

Directors welcomed the authorities' conjunctural fiscal stimulus packages in the past four months aimed at supporting domestic demand and guarding against cumulating the drop in consumer and business confidence. They considered these packages timely. Directors welcomed in particular the significant impetus offered by the latest package. Among the components of the package, they noted that the accelerated reduction in social security contributions and the step up of spending on infrastructure projects are well-targeted and likely to provide both short-term stimulus and lasting benefits. Directors acknowledged the complexity of judging precisely the degree of optimal fiscal impulse when the global situation is in rapid flux, often in unexpected ways. In view of the sizeable recent deterioration in economic prospects and given Germany's fundamentally strong fiscal position, a number of Directors would have favored an even more proactive stimulus. A number of others, however, supported the authorities' considered approach of maintaining equal emphasis on discretionary measures to spur the economy and adhering to fiscal prudence. All Directors welcomed the authorities' reiteration of their commitment to medium-term fiscal sustainability, which will be crucial for ensuring the long-term credibility of public finances in accordance with the Stability and Growth Pact.

Directors noted that trends in healthcare costs and debt accumulation by the states remain a concern. Further rationalization of pharmaceutical expenditures and strengthened efficiency-enhancing competition remain attractive avenues for containing healthcare costs. Directors noted the possible benefits from more state tax autonomy and a redesign of supplementary federal grants to improve states' incentives for fiscal discipline. They welcomed the proposed fiscal rule limiting the structural budget balance to close to zero, and recommended that it be applied also to the states.

Public Information Notices (PINs) form part of the IMF's efforts to promote transparency of the IMF's views and analysis of economic developments and policies. With the consent of the country (or countries) concerned, PINs are issued after Executive Board discussions of Article IV consultations with member countries, of its surveillance of developments at the regional level, of post-program monitoring, and of ex post assessments of member countries with longer-term program engagements. PINs are also issued after Executive Board discussions of general policy matters, unless otherwise decided by the Executive Board in a particular case. The staff report (use the free Adobe Acrobat Reader to view this pdf file) for the 2008 Article IV Consultation with Germany is also available. 
Germany: Selected Economic Indicators

\begin{tabular}{|c|c|c|c|c|c|}
\hline & 2004 & 2005 & 2006 & 2007 & 20081 \\
\hline Economic activity and prices & \multicolumn{5}{|c|}{ (Change in percent, unless otherwise noted) } \\
\hline Real GDP & 1.2 & 0.8 & 3.0 & 2.5 & 1.3 \\
\hline Net exports 2/ & 1.4 & 0.7 & 1.0 & 1.4 & -0.2 \\
\hline Total domestic demand & -0.1 & 0.0 & 2.1 & 1.1 & 1.6 \\
\hline Private consumption & 0.1 & 0.2 & 1.0 & -0.4 & 0.0 \\
\hline Gross fixed investment & -0.3 & 1.1 & 7.7 & 4.3 & 4.1 \\
\hline Construction investment & -3.9 & -3.0 & 5.0 & 1.8 & 2.7 \\
\hline Gross national saving (percent of GDP) & 21.8 & 22.1 & 23.7 & 25.9 & 25.0 \\
\hline Gross domestic investment (percent of GDP) & 17.1 & 16.9 & 17.6 & 18.3 & 19.0 \\
\hline Labor force $3 /$ & 43.0 & 43.3 & 43.2 & 43.3 & 43.4 \\
\hline Employment 3/ & 38.8 & 38.8 & 39.0 & 39.7 & 40.3 \\
\hline Standardized unemployment rate (in percent) & 9.2 & 10.6 & 9.8 & 8.4 & 7.3 \\
\hline Unit labor costs (industry; hourly data) & -3.1 & -4.2 & -4.0 & -3.1 & -1.2 \\
\hline GDP deflator & 1.0 & 0.7 & 0.5 & 1.8 & 1.4 \\
\hline Harmonized CPI index & 1.8 & 1.9 & 1.8 & 2.3 & 2.8 \\
\hline Public finance & \multicolumn{5}{|c|}{ (In percent of GDP) } \\
\hline General government balance 4/ & -3.8 & -3.3 & -1.5 & -0.2 & -0.1 \\
\hline Structural government balance & -2.6 & -2.3 & -1.2 & -0.3 & -0.3 \\
\hline General government gross debt & 64.7 & 66.4 & 66.0 & 65.0 & 68.7 \\
\hline Money and credit & \multicolumn{5}{|c|}{ (Change in percent over 12 months) } \\
\hline Private sector credit $5 /$ & -0.2 & 2.2 & 3.5 & 3.2 & 6.6 \\
\hline M3 5/ & 2.2 & 5.2 & 4.9 & 10.6 & 11.1 \\
\hline Interest rates & \multicolumn{5}{|c|}{ (In percent) } \\
\hline Three-month money market rate $6 /$ & 2.1 & 2.1 & 3.7 & 4.8 & 3.4 \\
\hline Ten-year government bond yield $6 /$ & 4.1 & 3.6 & 3.8 & 4.3 & 3.2 \\
\hline Balance of payments & \multicolumn{5}{|c|}{ (In billions of euros, unless otherwise noted) } \\
\hline Exports 71 & 850.3 & 924.6 & $1,056.3$ & $1,148.6$ & $1,206.6$ \\
\hline Imports 7/ & 739.9 & 805.1 & 925.5 & 975.6 & $1,047.6$ \\
\hline Trade balance (percent of GDP) & 6.3 & 6.4 & 6.3 & 7.8 & 7.1 \\
\hline Current account balance & 102.9 & 116.6 & 141.5 & 184.2 & 149.4 \\
\hline Current account (percent of GDP) & 4.7 & 5.2 & 6.1 & 7.6 & 6.0 \\
\hline Exchange rate & \multicolumn{5}{|c|}{ (Period average) } \\
\hline Euro per U.S. dollar 6/ & 0.80 & 0.80 & 0.80 & 0.73 & 0.74 \\
\hline Nominal effective rate $(1990=100) 6 /$ & 115.7 & 114.7 & 114.9 & 119.7 & 115.8 \\
\hline Real effective rate $(1990=100) 8 /$ & 105.5 & 102.2 & 99.1 & 97.9 & 95.1 \\
\hline
\end{tabular}

Sources: Deutsche Bundesbank; IMF, International Financial Statistics; IMF, World Economic Outlook; and staff projections.

1/ 2008 estimated, unless otherwise indicated.

2/ Contribution to GDP growth.

3/ Domestic definition on a national accounts basis; according to new integrated system of economic accounts (ESA95).

4/ On a national accounts basis; according to new integrated system of economic accounts (ESA95).

5/ Data for 2008 refer to November. M3 refers to Germany's contribution in the euro area.

6/ Data for 2008 refer to December.

$7 /$ Goods and services.

8/ Based on relative normalized unit labor cost in manufacturing. Data for 2008 refer to December. 


\section{Statement by Klaus-Dieter Stein, Executive Director for Germany January 9, 2009}

We would like to thank the staff for a concise and focused report which offers a balanced reflection of what my authorities considered to be a very constructive and candid dialogue during the consultations.

We broadly share staff's assessment that the environment for conducting economic and fiscal policy has become extremely challenging given the worsening of economic indicators as the financial crisis spills over to the real ecnomy. However, employment and real disposable income have expanded in Germany almost up to the end of 2008 as some key elements which have triggered and reinforced the crisis of the global economy have not featured highly in the past course of the German economy: housing prices remained stable in recent years, predominantly deposit-based financing of lending, low exposure of pension system to capital market developments, low debt ratios of corporates and households. To be clear, however, my authorities have and will act forcefully to the abrupt change in economic conditions. Essentially, this crisis will be temporary and the crisis response of the German government is being carefully framed in order to protect the economy from harm, yet not foregoing the commitment to credible economic and fiscal policies based on sound principles which my authorities deem crucial to master the long-term budgetary challenges and to maintain confidence in a sustainable fiscal policy.

\section{Economic Situation}

\section{Highly integrated in the world and European economies, Germany faces severe strains from a global demand shock as the financial crisis leaves its marks on the real economy. The economy has entered a recession in 2008 and GDP is likely to contract sharply in 2009 as production will continue to decline following a reversal in export demand. Revised growth forecasts of major economic research institutes range between 1.4 percent and 1.6 percent for real GDP growth in 2008 and between -2.7 percent and -1.2 percent for 2009 . For 2010 the economy is expected to gradually stabilize. The government will issue a revised official growth forecast on 21 January.}

\section{The high degree of uncertainty at the current juncture notwithstanding, my} authorities consider the fundamentals of the German economy as still being reasonably strong. The corporate sector has in recent years moved forward with consolidation of balance sheets and the maintenance of strong cash-flows while pricecompetitiveness has been favorable. Thanks to higher wage growth and a turnaround in 
commodity prices, aggregate demand conditions have been upheld. Nevertheless, domestic demand will not be able to make up for the drastic drop in German firms' foreign order volume - identified as the primary shock and principle source of the current slowdown.

\begin{abstract}
Although the private sector has until recently resisted the economic downturn, a significant fall in demand for capital investment goods and tighter credit conditions will leave their mark. A credit crunch triggered by financing shortfalls in the banking sector is however unlikely at the current juncture. Nevertheless, corporate sector investments will be scaled back significantly given lower capacity utilization, revised profit forecasts and more restrictive financing conditions as corporate bond spreads have increased.
\end{abstract}

\title{
My authorities concur with staff that business sentiment has been deteriorating
} more rapidly than in previous downturns. Yet, they emphasize that the danger of selffulfilling pessimistic expectations is clearly prevalent. Against this background, "proactive" projections are to be avoided as indicators more directly mirroring real developments draw a more benign picture. For example, in October, industrial capacity utilization was still slightly above its long-term average. Furthermore, the projected decline in the output gap is not exceptionally strong compared with the previous downturn.

\section{Financial sector}

The current situation in the financial sector remains strained. Interbankmarkets are still not functioning properly and confidence is still lacking. The profit situation of financial institutions remains depressed by the high losses ascribed to structured and other products, and falling interest margins. Yet, an important segment of the market has based its business model mainly on deposits and is therefore more shielded against the risks of the wholesale market. Overall, financial sector stress is nevertheless expected to persist for the next quarters as the economy is not likely to recover before 2010 .

The government has responded speedily and decisively to the financial crisis. The new financial market stabilization law has been implemented rapidly and the stabilization fund (Sonderfonds Finanzmarktstabilisierung - SoFFin) is increasingly used by banks. From the start, the financial rescue package has had a dual approach aimed at promoting liquidity and solvency. In order to eliminate liquidity shortages and to support refinancing in the capital markets, SoFFin has been authorized to guarantee newly issued refinancing instruments. The Fund may also recapitalize financial institutions, in particular through the purchase of shares or silent participations. With the option of 
acquiring problematic assets, it can also improve capital ratios. At present, 95 bn euros of guarantees are committed (out of an overall envelope of 400 bn euros) and 8.2 bn euros in recapitalization support (out of maximum envelope of 80 bn euros).

The central principle of SoFFin - its balanced focus and voluntary participation has so far proven adequate. The originally feared stigmatization of participating institutions cannot be confirmed. The principle of voluntary participation ensures that primarily the owners are accountable for the solution of individual problems of their institutions. SoFFin is only intervening on a subsidiary basis. In fact, several banks managed a recapitalization on their own without using the recapitalization credit line of SoFFin. In 2009, a new asset-class will be established (government-guaranteed bank bonds) clearly improving incentives for banks to participate in SoFFin.

\section{My authorities share staff's recommendation to move forward with the}

restructuring of the Landesbanken. They consider that substantial reform including a downsizing and the development of a viable business model is needed. State governments have indicated that they would like to preserve their decision autonomy with respect to the future role of their institutions. The institutions concerned have also already considered various options by themselves.

\section{My authorities consider the German bank resolution framework as broadly}

adequate. Section 46b of the Banking Act provides the possibility to (i) issue a ban on sales and payments by the concerned institution and (ii) prohibit the acceptance of payments not intended for the discharge of debts to the institution (moratorium). Objections by the institutions (and their shareholders) have in principle no postponing effect. This moratorium allows the supervisor, shareholders, and other stakeholders to negotiate a rescue plan. Therefore, my authorities consider that BaFin as the supervisor has sufficient instruments at hand to deal with a quickly evolving problem situation in an institution.

As to supervision, the revised guideline governing the respective responsibilities of BaFin and the Bundesbank ensures the clear division of labor in the field of banking supervision in Germany. Cooperation during the recent financial crisis has proven to be efficient. The division of responsibilities ensures on the one hand that the Bundesbank has access to all supervisory information. On the other hand, synergies from banking supervision and monetary policies can be gained without questioning the independence of the Bundesbank.

\section{Fiscal policy}


The German government is fully committed to the rules of the Stability and Growth Pact at EU level. This pact provides the framework under normal circumstances to achieve and maintain a budgetary position of close to balance or in surplus. For exceptional circumstances, it provides the budgetary space to weather any economic downturn, in the first place through the full operation of automatic stabilizers and, if needed, also through additional fiscal policy measures.

\section{EU level coordination of additional fiscal policy measures requires primarily a common understanding on the application of the Pact at the current juncture - given the exceptional circumstances. In light of the unusual degree of uncertainty about the impact of any specific measures, it is crucial to give due account of countries' individual circumstances. For my authorities, structural consolidation of public budgets remains the key objective given the challenges to long-term sustainability of public finances. Framing short-term (temporary) policy responses accordingly will avoid putting hard-won structural consolidation at risk. This is crucial for confidence-building underpinning that policies are viable to guarantee sound public finances in the monetary union.}

The government has responded to the global economic slowdown speedily and decisively with an important fiscal stimulus package - which is already in effect designed to secure growth and employment. The package adopted by the Cabinet on 7 October and 5 November 2008 predominantly contains growth-oriented measures that can be implemented in a timely manner. The objective is to create strong stimuli for private and public-sector investments, inter alia by investment funding to SMEs, tax incentives, targeted support to families and infrastructure investment. Furthermore, the Federal Constitutional Court has reinstated the commuting allowance (tax subsidy) which has an additional stimulus effect. The total volume of both, the package and the commuting allowance in 2009 and 2010 will amount to approximately 40 bn euros (or over $1 \frac{1}{2}$ percent of GDP).

My authorities underline that the decisive factor with regard to actually stimulating economic activity is not solely the level of public sector spending, but the economic impact of the measures adopted. The high degree of uncertainty on the impact of specific policies notwithstanding, the measures adopted by the federal government are targeted and will mainly remain in effect for a limited time only, while having a lasting impact. In the coming years, some measures of the package will facilitate investments and orders from enterprises, private households and regional and municipal governments. The measures will cost 11 bn euros in two years but are expected to trigger 50 bn euros in private investment. An additional fiscal stimulus package is currently under consideration. 
My authorities emphasize that a short-term fiscal spending strategy - without ensuring medium-term fiscal sustainability - may not deliver the effectiveness wished for. A loss of confidence in fiscal sustainability would significantly aggravate the crisis. The government is considering the implementation of a new constitutional fiscal rule which would ensure a compensation of short-term discretionary fiscal policy measures in the next upswing. My authorities explicitly welcome the staff's assessment on the usefulness of such a rule which is currently being discussed in the Federalism Commission II.

\section{Furthermore, my authorities welcome the staff's recommendation for a new} preventive budget surveillance mechanism. To this end, my authorities have recommended the establishment of a stability council. On the other hand, staff recommends that fiscal rules at the level of individual states need to be altered to ensure greater tax autonomy and to avoid pro-cyclical expenditure behavior at state level. My authorities are more cautious to these recommendations as, (i) the expenditure fluctuations of individual states would be higher without the federal financial equalization and (ii) the revenue base, in particular between east and west German states, is very different so that more tax autonomy would reinforce revenue shortfalls and render budget consolidation in the end more difficult.

\section{Structural Reform}

\section{The structural position of the German economy remains sound, but reform} challenges remain. German economic policy has - over the recent years preceding the crisis - been targeted (i) at further increasing trend growth and implementing policy responses to the challenges posed by population ageing, while (ii) at the same time anchoring reforms in a sufficiently broad consensus balancing efficiency considerations with social security concerns. The strategy has served Germany well and will remain valid over the medium-term. Going forward, the government will advance further reforms in the health care sector as cost-saving measures and efficiency-enhancing competition in the health care system are important to ensure sustainable public finances.

Continual effects of previous growth-oriented structural reforms. The structural reform measures referred to in the context of last year's Article IV consultation, the business tax reform and the significant reduction of contribution rates to unemployment insurance result in the coming years in a relief for enterprises and individuals of well above 1 percent of GDP per annum. In addition, federal budget spending for research and development will continue to increase in 2009 and 2010. 